
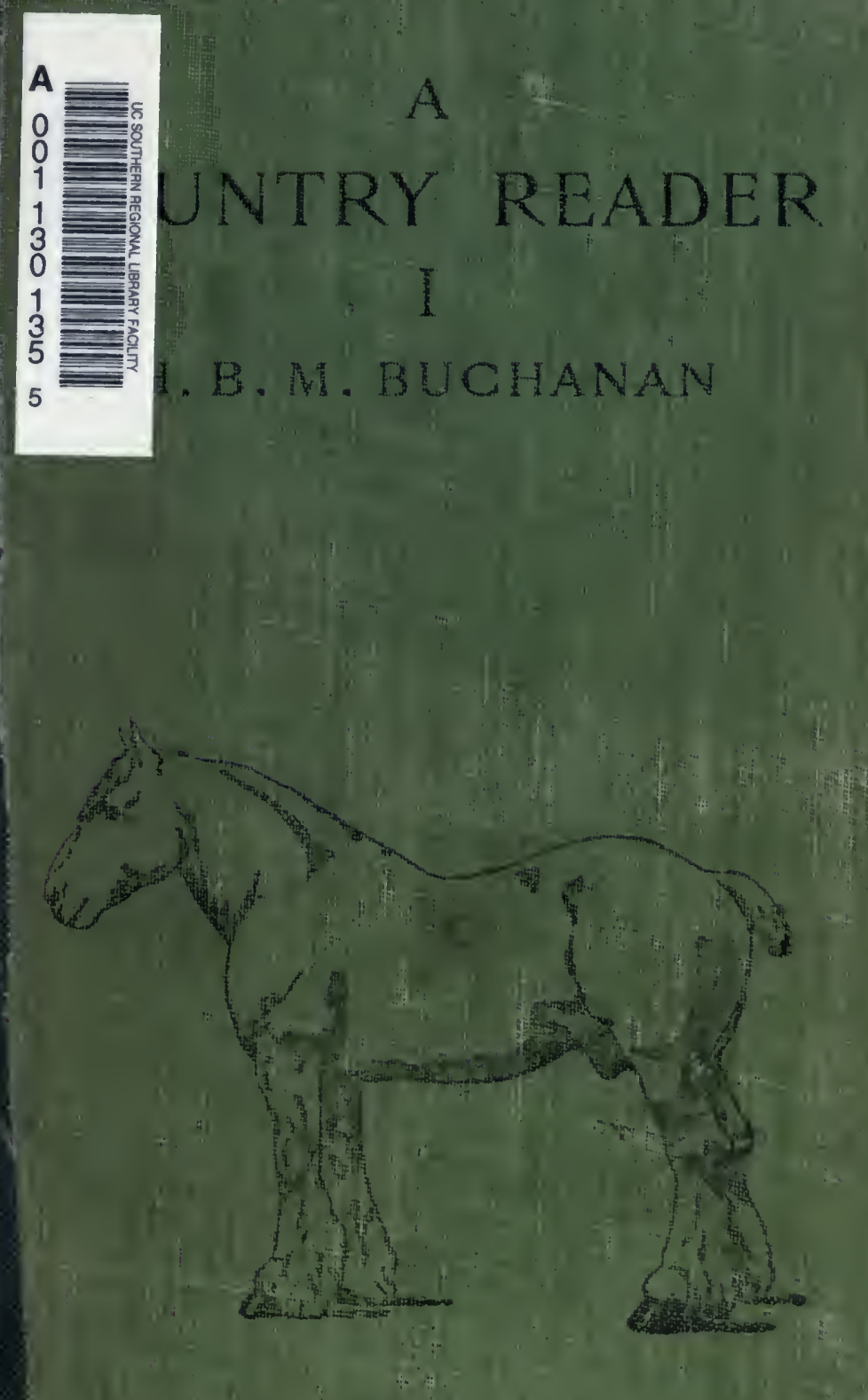

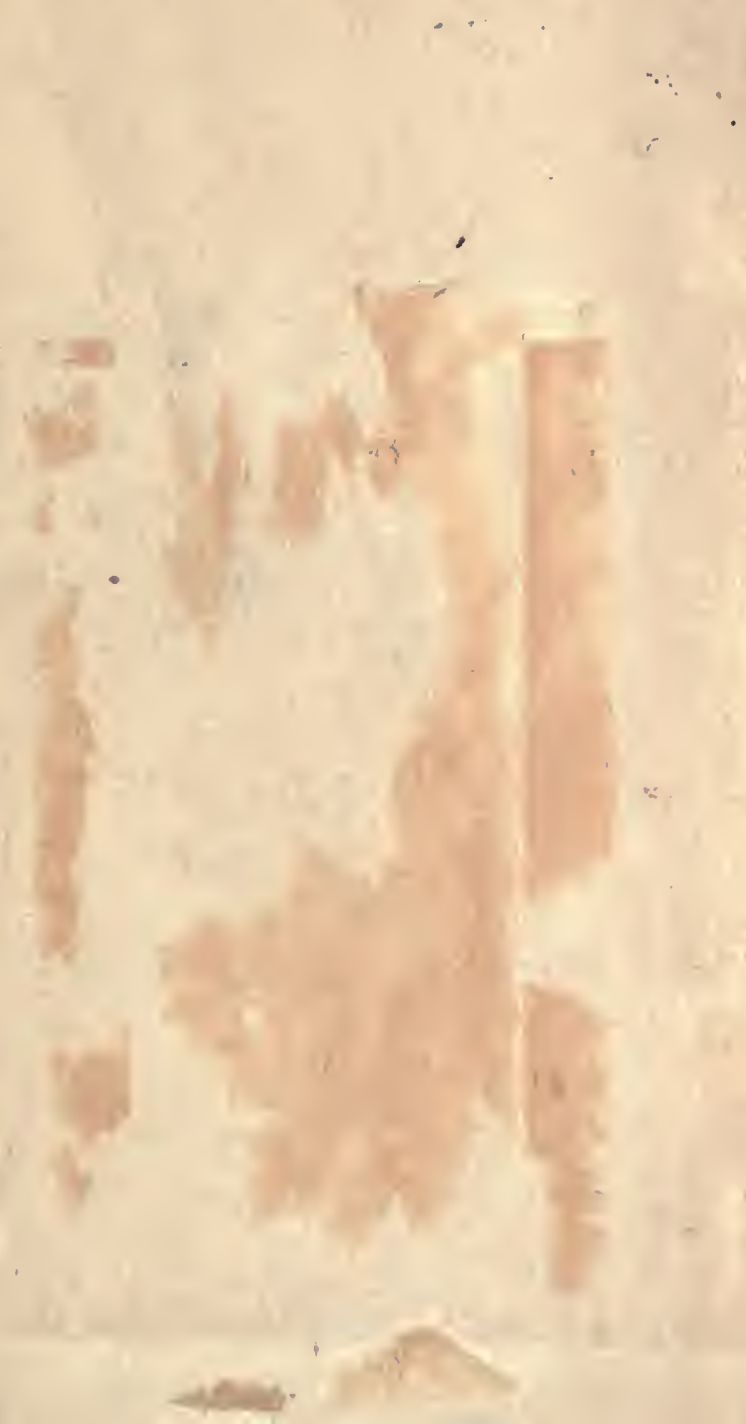


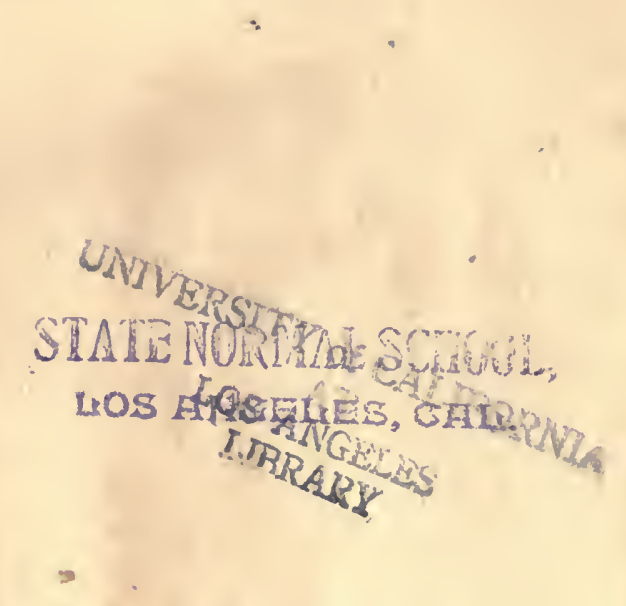

UNIVERSTTX of CAITHORNDE

\author{
LUS ANCLEDS \\ THILARY
}


Digitized by the Internet Archive in 2007 with funding from Microsoft Corporation 
A COUNTRY READER 
s. 


\section{A COUNTRY READER}

I.

BY

H. B. M. BUCHANAN, B.A. (Cantab.) MEMBER OF THE CENTRAL CHAMBER OF AGRICULTURE

WITH SIXTY-SEVEN ILLUSTRATIONS

"To make two blades of grass grow, where one grew before, is noble work."

\section{3}

迅ondon

MACMILLAN AND CO., Limited

NEW YORK : THE MACMILLAN COMPANY

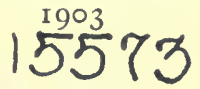

$2 r_{n}^{2} N \quad 1907$ 
First Edition 1901.

Reprinted 1902. Revised 1903.

GLASGOW: PRINTED AT THE UNIVERSITY PRESB

BY ROBERT MACLFHOSE AND CO. 


\section{5 \\ B 85 c}

\section{PREFACE.}

This Country Reader is not meant for the very young children, but for the elder children of our village schools-children who are supposed to read with ease, and who are expected to know the meaning of ordinary English words.

I have striven to use the shortest words and simplest sentences at my command, and to make my meaning as plain as possible.

I should like to remind my readers that this little work is a Reader and not a text-book; and so, while endeavouring that it should contain accurate modern knowledge, I have tried with my whole heart to make it live with interest.

To arouse the observation of the children, and so excite an interest in, and fondness for, the varied life and work that lies around them, has been my supreme object.

I am indebted to the following works, which I have freely consulted: "Elementary Text-Book for use in Irish National Schools," by Thomas 
Carroll; "Agriculture for use in the Public, Separate and High Schools of Ontario," by C. C. James; "Cable Series of Agricultural TextBooks," by Wrightson and Munro; "Elements of Agriculture," by W. Fream; "Wild Traits in Tame Animals," by Louis Robinson; Agricultural Zoology, by Dr. T. Ritzema Bos.

I am, however, specially indebted to the respected tenants, small-holders, cottagers, and agent of my estate, who have most generously, and I believe with truthfulness, placed at my disposal the results of their lengthened and varied experiences. Many a pleasant and most profitable hour have I passed in their company, listening, I am sure they would say, with respectful sympathy to their reasons for doing this and doing that.

During the time that I have been able to reside on my property and amongst my people, I have attended the village school, where for half an hour or so most mornings I have talked to the children on the matters mentioned in this book.

I have been struck with and gratified by the interest that the children have shown, and the amount of real useful knowledge they have picked up, with little effort to themselves, and with delight and comfort to their teacher. 
I have wandered about the country deeply interested in every style of agriculture, observing, taking notes, and thinking for myself, and consulting everyone interested in agriculture who would converse with me.

Therefore, I venture to hope that this little work may be of some slight service to the children and teachers of our day schools, both in the town and country, and also that it will be found suitable for the students in the evening schools.

I am indebted to the proprietors of "Country Life" for many of the illustrations.

I am also indebted to Mr. R. R. C. Gregory, member of the Executive of the National Union of Teachers and late chairman of the Rural Schools Committee, who has kindly read and revised my proofs.

H. B. M. BUCHANAN.

HALES, Nr. Market-Drayton. 


\section{CONTENTS.}

Part I. Farm Life of the Country-

PAGE The Horse, - $\quad$ - $\quad$ - $\quad$ - $\quad$ - 1 About Cattle, - $\quad$ - $\quad$ - $\quad$ - $\quad$ - $\quad 37$ The Pig, - - $\quad$ - $\quad$ - $\quad$ - 73 The Sheep, - $\quad$ - $\quad$ - $\quad$ - $\quad$ - $\quad$ - 98 Country Dogs, - $\quad$ - $\quad$ - $\quad$ - $\quad 116$ Poultry, - $\quad$ - $\quad$ - $\quad$ - $\quad$ - $\quad$ - $\quad$ - 139 Bees, - - - $\quad$ - $\quad$ - $\quad$ - $\quad$ - 156

Part II. Wild Life of the Country-

\begin{tabular}{llllllll} 
Animals, & - & - & - & - & - & - & -179 \\
Birds, - & - & - & - & - & - & - & -196 \\
Insects, & - & - & - & - & - & - & - \\
\hline
\end{tabular}




\section{A COUNTRY READER.}

\section{PART I. FARM LIFE OF THE COUNTRY.}

\section{THE HORSE. \\ 15573}

THE horse has been the servant of man for a very long time; so long ago is it, that we have no written record of when it began, but we do know that at one time the horse led a wild life and wandered in large herds over the great plains of the world.

When horses lived in this wild state, they had many enemies who tried to kill and eat them, but their special enemy was the grim Grey Wolf, with his never-ending hunger and slow but untiring gallop.

Let us now try to picture a scene of those long bygone days.

We see a wide, up and down, undulating plain, stretching as far as the eye can reach, a plain mostly hard and dusty, with dry, wiry grass growing here and there; and we see a herd of wild horses wandering about not far from each other, trying to satisfy their hunger with the dry scanty herbage. And as we look we see a pack 
of hungry wolves, who are trying every device to creep as near to the horses as possible without being seen by them.

At last one of the horses, the leader or the look-out horse it may be, because of his keen eyesight, or because of 'His 'quick sense of smell, sees his natural enemies, the wolves. Then with a loud snort and stamp of the forefoot, and with tail high in the air, he trots towards his companions. These signals of alarm are well understood by the herd, which at once ceases grazing, collects together, and gallops in a body towards the horizon.

Then the chase begins.

The wolves, with noses to the ground and tails in the air, strive to come up with their prey. These elever animals are up to all sorts of devices to accomplish this. The pack will divide. One portion will follow on the direct trail of the horses, another portion will try to head the horses off, as it is termed, so that they may bring them round. Some, after a time, will lie down to rest, while others will endeavour to bring the herd of horses round to where the resting wolves are lying in concealment, so that a fresh relay of rested wolves may take up the chase with renewed vigour. The swiftest, soundest, and strongest horses are sure to escape, but the wolves hope that in the herd there may 


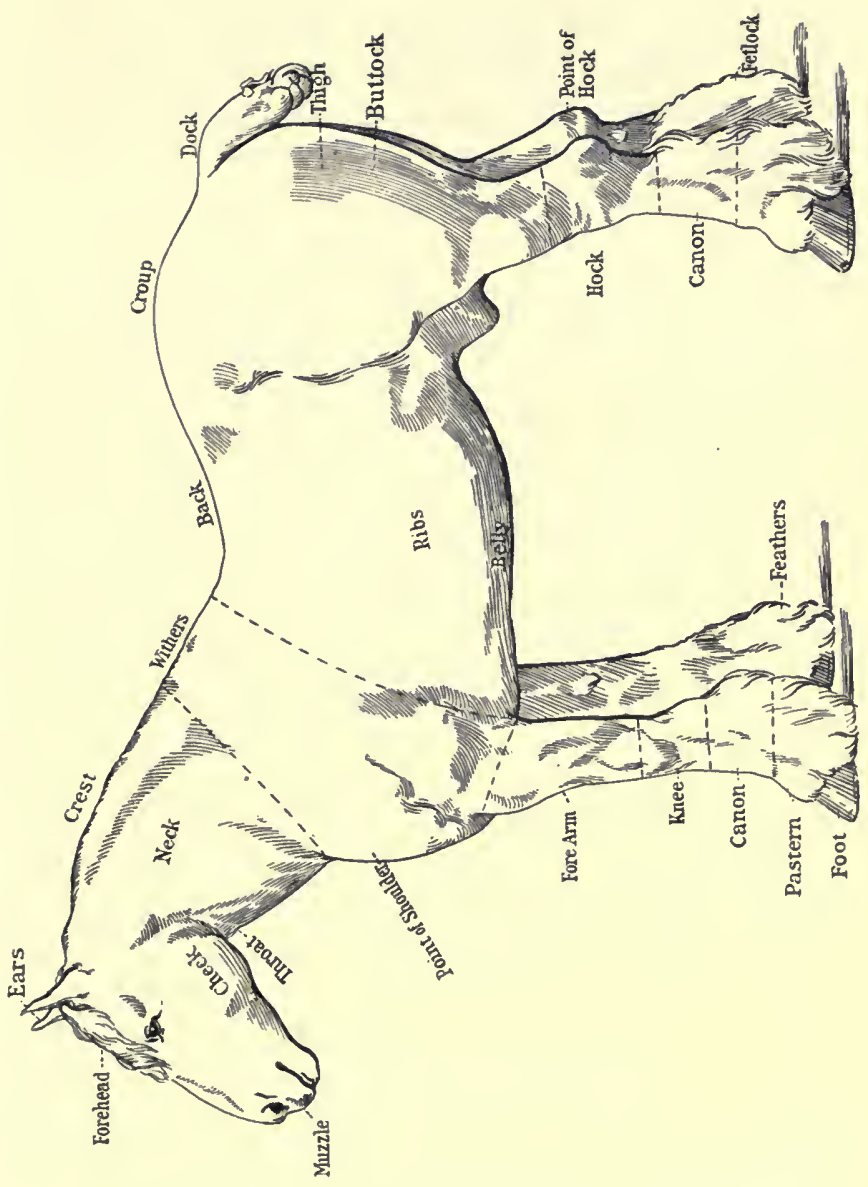


be one or more a little lame, touched in the wind a bit, or a little out of condition. If there be such an unfortunate horse, the wolves have learnt from experience that this unsound and weaker horse will not be able to keep up with the rest, but will go slower and slower in pace, till it lags behind its companions, which will allow the gaunt wolves with their slow, untiring gallop to approach nearer and nearer, till the unsound or slower horse is dragged down and eaten by its hungry pursuers.

Now you can at once understand by this little imaginary scene, that in the course of numbers and numbers of years the sick and unsound horses would be unable to escape their enemies, while those horses that were keenest of eyesight, quickest of hearing, soundest in wind, swiftest in pace, hardest in endurance, strongest in leg, would survive.

So you see how these enemies of the horse, together with the hard life on the immense plains, that existed long ages ago in Europe and Asia helped very slowly and very gradually to perfect that form of life which we call a horse, a form of life suitable for man to use in his wars, in his hunting, for his pleasure of riding and driving, and for helping him to cultivate his fields, and for carrying his heavy loads.

When man began to use a horse as his servant, 
we at present do not know. Nor can we say for certain what was the exact colour and appearance of these wild horses, because we possess no picture or written description of them as they wandered in their wild state. But we have found some of their bones, which have been pieced together by great and clever men, and are now to be seen in our Museums.

We know, however, that man, by selecting what he requires, and breeding from that selection, has considerably improved on these wild horses.

Remember that in the country you can by your observation, selection, and knowledge improve, and so make more profitable, everything that lives and grows about you.

By selecting and breeding, man has produced many classes or grades of horses. It would take too long to enter into detail about all these different grades, but it may be said that there are four classes of horses in most general use (1) The Thoroughbred; (2) The Hunting or Riding Horse; (3) The Carriage Horse; (4) The Cart Horse or Shire Horse.

\section{The Thoroughbred Horse.}

The Thoroughbred (see illustration of the racehorse "Orme") has been produced by mating a light English mare with the Arabian and 
Barb horses, and has been bred for speed and endurance. A thoroughbred, therefore, ought to have clean-cut sinewy limbs, with long racing quarters, so as to allow the hind legs when galloping to stretch well under the body with the longest possible sweep. Its pasterns ought to be long and flexible, so that when the animal is cantering or galloping the motion is as easy as sitting in a rocking chair; its skin soft, its hair fine and velvety. A thoroughbred's head ought to show signs of refinement, and be well put on to the shoulder, so that it is carried with an air of pride, spirit, and froedom. The head ought not to be too long, and ought to possess good width between the eyes. The nostrils ought to distend, so that after a good gallop they expand almost round, and show clearly the red inside, to allow the wind to come out clear, even, and strong. In other words, a thoroughbred is said to possess good quality when it exhibits a fine shape, high spirit, and a courage and endurance that will persevere till it drops.

Many a courageous, high-spirited horse, at the bidding of its master, has galloped on, showing little or no signs of distress, till a quiver or uneven lurch of the body was the first sign to the rider that the noble beast had done all that it could, and it fell to die. 


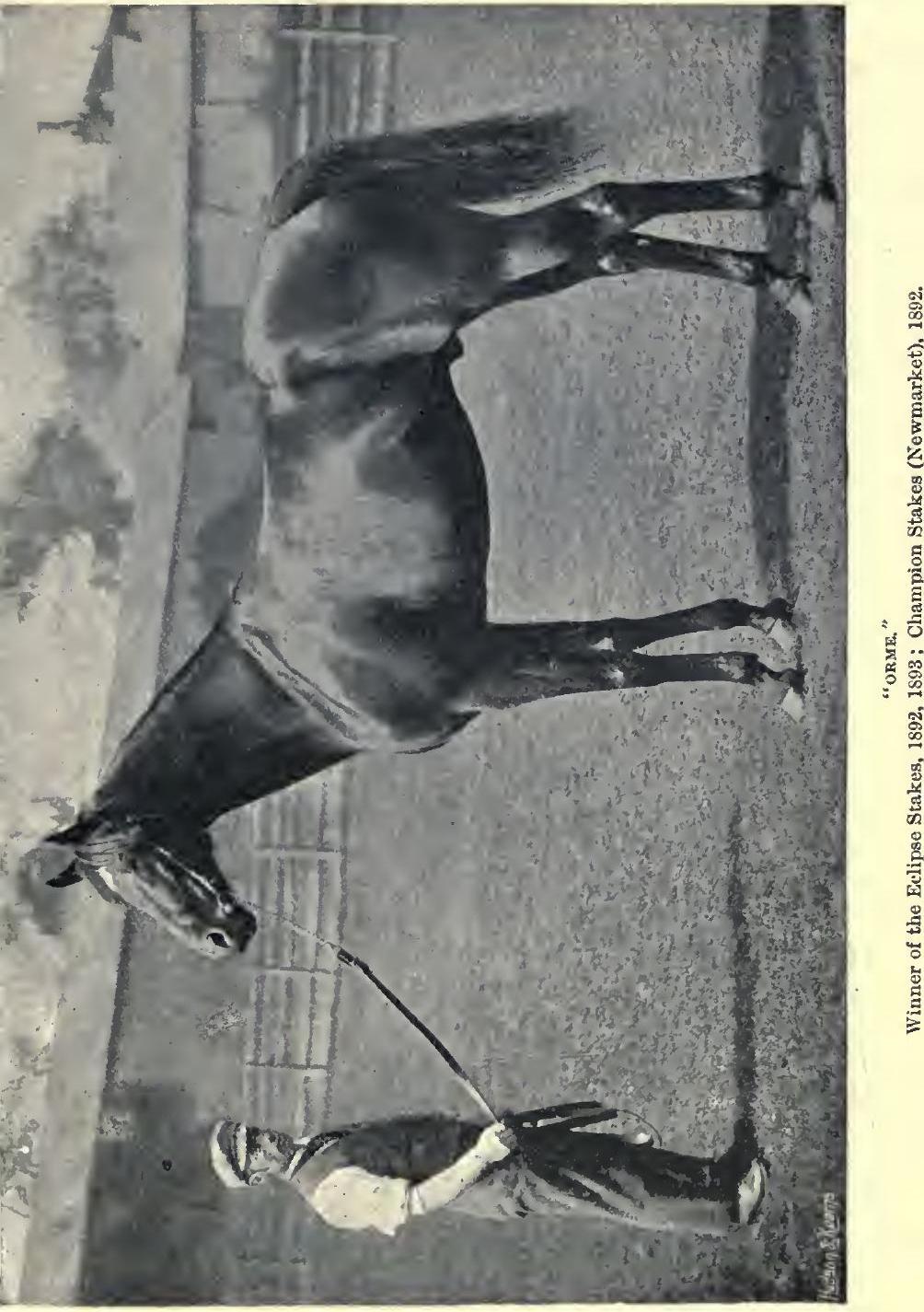


So beautifully shaped is the body for speed, so clean and hard the legs, so well knit the frame, so sound the wind and condition, so keen the eyesight, so courageous the heart, that these beautiful ereatures have been said to gallop for a short distance as fast as an ordinary express train can travel when moving at its best, namely, sixty miles per hour.

To produce such an animal as this means generations of careful selection and breeding, the best known system of stabling, grooming, training, feeding, and caring for generally. In consequence of this careful breeding and training, these thoroughbreds are often very nervous, and therefore impatient and restless, and, if roughly and cruelly treated, their disposition or temperament is easily spoilt, and they become vicious and dangerous.

As these horses have been bred and trained principally for galloping, they are bad trotters and walkers - they do not lift their legs well off the ground - and are seldom used for hunting or carriage work.

\section{Riding or Hunting Horse.}

A hunter or riding horse ought to have a good proportion of the thoroughbred about it, but it is thicker and stronger than the thoroughbredup to more weight, as it is termed. The quarters 


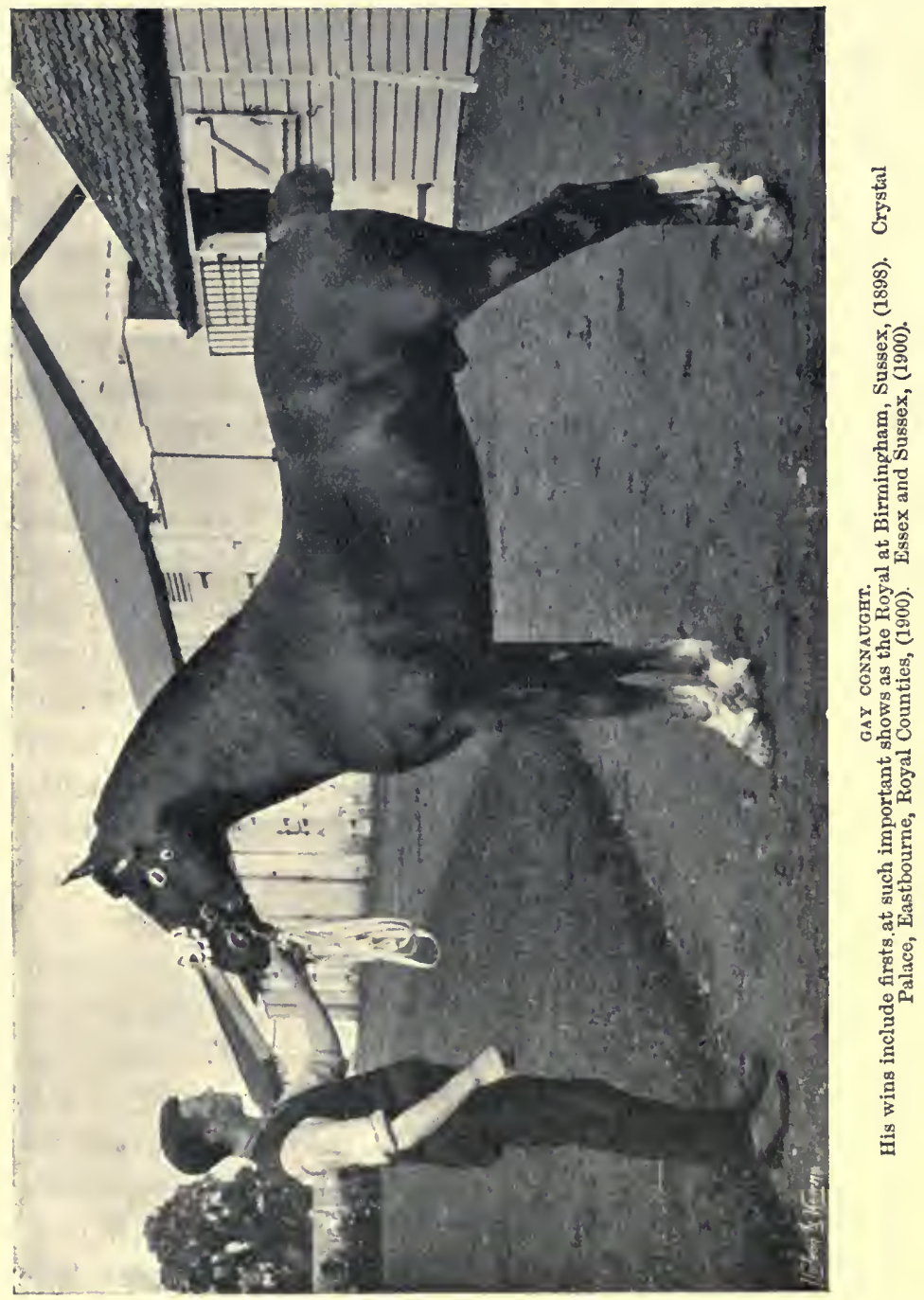


ought to be long and powerful, its thighs muscular, its hocks clean and neatly shaped, the head clean and long, with a look of good breeding about it.

A riding horse cannot, as a rule, gallop as fast as a thoroughbred, but its other paces are better suited for giving pleasure in riding. It lifts its feet well off the ground with good all-round action. It can walk and trot faster and with greater safety than the thoroughbred. A good walk and trot is very essential in a riding horse. For when you ride you walk and trot your horse far more than you gallop it. In fact, no good rider who knows anything of, or cares anything for, his horse, unless absolutely obliged, ever canters or gallops along the road or on a hard surface, because the jar of the hard surface tends to break the feet and cause all manner of mischief to arise in the legs, that in time may send the horse lame, or cause it to become what is termed unsound.

In selecting a riding horse, there are certain points which are very essential. It is neccssary to sce where he will carry his saddle. The shoulders and withers ought so to place the saddle that the weight of the rider is thrown more on the quarters than on the front legs. In other words, when you are in the saddle, you ought to have a good deal of the horse in front of you. The 
reason for this is very plain. If your weight is well off the front legs, and on the powerful quarters, there is less chance of the horse stumbling and falling with you. And remember this, that it is the quarters, hind legs, and hocks that are the propelling power of the horse, whether in walking, trotting, cantering, or galloping. The front legs simply direet the horse and keep him steady.

When you require a horse for earrying you on his back or for jumping, the quarters and hind legs ought to be sufficiently powerful to enable the horse to do the work expeeted of him. If you watch a horse jumping, you will see that when he comes near the jump, he will prick his expressive and beautiful ears, which shows that he is thinking hard of how best he ean get over, and then when he gets within a few paces of the jump, he raises his front legs first, and by his will gathers himself together, and then by means of his quarters, hind legs, and hocks, he gives the necessary impulse that earries his rider over the hedge, ditch, or gate.

You will note that the foree or power that carries your horse over the jump is due to those quarters and wonderful hocks. Let there be the slightest weakness in one of those hocks, and your horse would not have the strength to elear the jump, but very probably would eatch his 
front legs in the hedge or rail, and fall on his head the other side, and might break his own neck and yours into the bargain.

You can thus at once understand how important it is that a riding horse's hocks should be clean and strong, and the quarters muscular, well-shaped, and powerful.

There is another important point in a riding horse. The pastern joints should be long and flexible. There is nothing more graceful to watch in the movements of a horse than the working of good riding pasterns. These pasterns ought to be long and flexible, not upright or directly over the foot, and the motion ought to be as easy as the springs of the most perfectly balanced armchair. It is the flexible and yielding action of these pasterns that gives ease and comfort in riding. When you hear the expression "Riding him was like sitting in an armchair," you may be quite sure that the horse of which that was said was well and gracefully made, with flexible, long, yielding pasterns.

The pasterns of a cart horse are straight and directly above the foot, short, and with little give in them. The consequence of this formation is, that if you were to trot, canter, or gallop a cart horse, the motion - would shake you all to pieces, as the expression is, which of course means that the motion would 
shake you about so much as to be unpleasant, and you would find no pleasure in riding him.

A riding horse ought to be a good walker, a fast trotter, an easy eanterer, and a fairly fast galloper.

\section{The Carriage Horse.}

The carriage or coach horse should be a strong, well-bred animal. The horse that is used entirely for carriage-work is required mostly for walking and trotting, and is seldom called upon to canter or gallop. So the carriage horse must walk at a good pace and be a fast trotter. To be a fast trotter, he must lift his front legs well off the ground and throw them well forward, while the hind legs must come well under the body, with good and free hock action, in order to give the pace and strength to draw along with ease the vehicle that is behind. Sometimes you may have seen a carriage horse with what is termed high-knee action. This means that the front legs come up and down almost straight, which aetion of course does not carry the horse quiekly over the ground, and moreover the constant high up and down action, hammer hammer on the hard high road, creates great concussion to the front legs, causing them soon to wear out. Besides, this high up and down action is not natural to the horse, it has been artificially taught, and 
therefore is neither useful nor beautiful. But the moderately high action that throws the forelegs well to the front carries the horse over the ground at a good pace, and by lessening the concussion of the ground, enables a horse to last long and do much work.

If you notice a carriage horse going up a hill, you will see that almost all the power that he uses to drag up his load falls on the hind legs and hocks, so you can at once understand how necessary it is that the quarters should be strong and muscular, and the hocks clean and without blemish. Watch the riding horse's pastern move, as he walks by your side, and when a carriage horse with his stout courage is doing his very best to drag a heavy load up a hill. Watch in both cases the hocks and hind legs do their work, and if you care for a horse, and can admire the beautiful in form and action of the animals around you, you will reverence and wonder at what you see there.

As the carriage horse has not to carry a weight on his back, but to drag a weight behind him, his shoulders ought to be more upright, not so sloping as the riding horse; this enables the collar to fit the neck better, and so gives him more power to drag his load.

As horses have been bred for the purpose of galloping fast, so horses have been bred for 


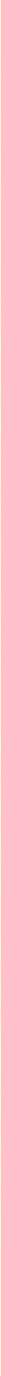


trotting fast, till the pace that some horses, especially the American horse, can trot is very swift. American trotting horses have been bred to trot as fast as many horses can gallop.

Don't forget that the first point to look for in all horses, whether for racing, hunting, driving, or dragging a heavy load, are first and foremost good sound feet and legs. Let these be unsound, the horse lame, or with a formation that with work will in time cause it to go lame, and the otherwise best horse in the world will be of no use to you, either for working, or for breeding from.

Then your horse must have a sound wind and perfect eyesight.

These are the three principal points to look for when you are buying a horse-clean, strong legs and feet, keen eyesight, and sound wind.

\section{The Cart Horse or Shire Horse.}

We now come to the horse that is specially the farmer's horse, and a beautiful creature have the farmers, by wise breeding and care, produced-powerful and beautiful outline of form, combined with great strength of body, gentleness of disposition, and a willingness to drag the heaviest load.

A 17-hand horse (a hand is four inches), dragging along $2 \frac{1}{2}$ tons of merchandise through 


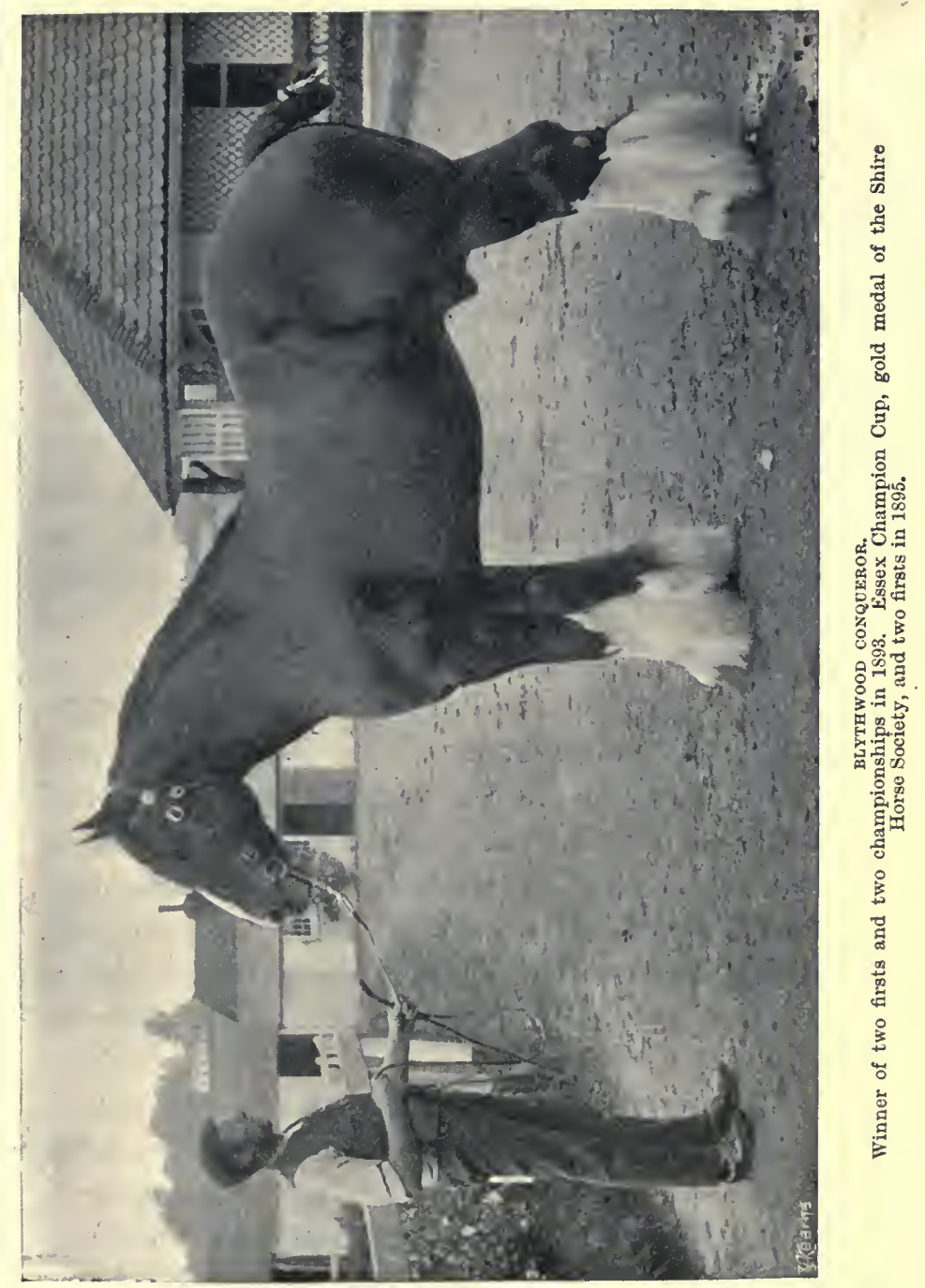


our cities with ease and brightness, as if he enjoyed the effort, his coat smooth and glossy like satin, his brass harness shining so that you can almost see your face in it, is indeed worthy of admiration.

Here we have a horse born and bred, not for pleasure, but for stern hard work.

To carry manure to the fields, to gather our crops, to carry our food, our clothing, our coals from place to place, so that we may all live gentler and happier lives, this is the work this massive, noble, gentle beast is doing for us. Let us always treat him kindly, and think well of him, for he deserves it at our hands.

The shire or cart horse is not called upon to trot, canter, or gallop; his usual pace is walking. Therefore he ought to be a fast walker, and he must be so shaped that when he is doing his work he can walk freely and easily. You will very soon use him up if you walk him constantly at a pace faster than his form and strength will allow. When ploughing or with a full load behind him, he ought to walk at about $2 \frac{1}{2}$ miles per hour.

The shire horse ought to have a medium-sized head, should be broad between the eyes, with neck fairly long and well arched. Its shoulders should be deep and strong, chest wide and full, back shortish and straight, ribs round and deep, 
hind quarters very powerful, long, and level, the feet wide and prominent at the heels, with bold free action, and with clean, heavy, flat bone, and soft silky hair. The long hair on the legs above the heels is called the feathers. These feathers ought to be silky. If a horse is coarse feathered, it is said to be a.sign of coarse, soft bone. These feathers on the legs save the horse from chills, and this is very important when you consider the time he has to stand about in wet mud and slush. None of us come to much harm if our feet and legs are warm; it is when these are cold and damp that we feel miserable and catch cold.

\section{How to Stable a Horse.}

The stable should be airy, ventilated from the top, well lighted, and free from offensive smells. The drains should drain outside the stable into what is termed a covered trap. Above everything, there should be no draughts in a stable, as there is nothing so likely to give a horse a bad cold as a draught. In fact a draught is bad for everything that grows and lives,-man, animals, and plants.

It is well known that a horse seldom or never catches cold in the open fields, even if he is kept out through the severest winter, provided of course he can get sufficient heat-giving food. If a horse's coat stands up, and his ears feel cold 


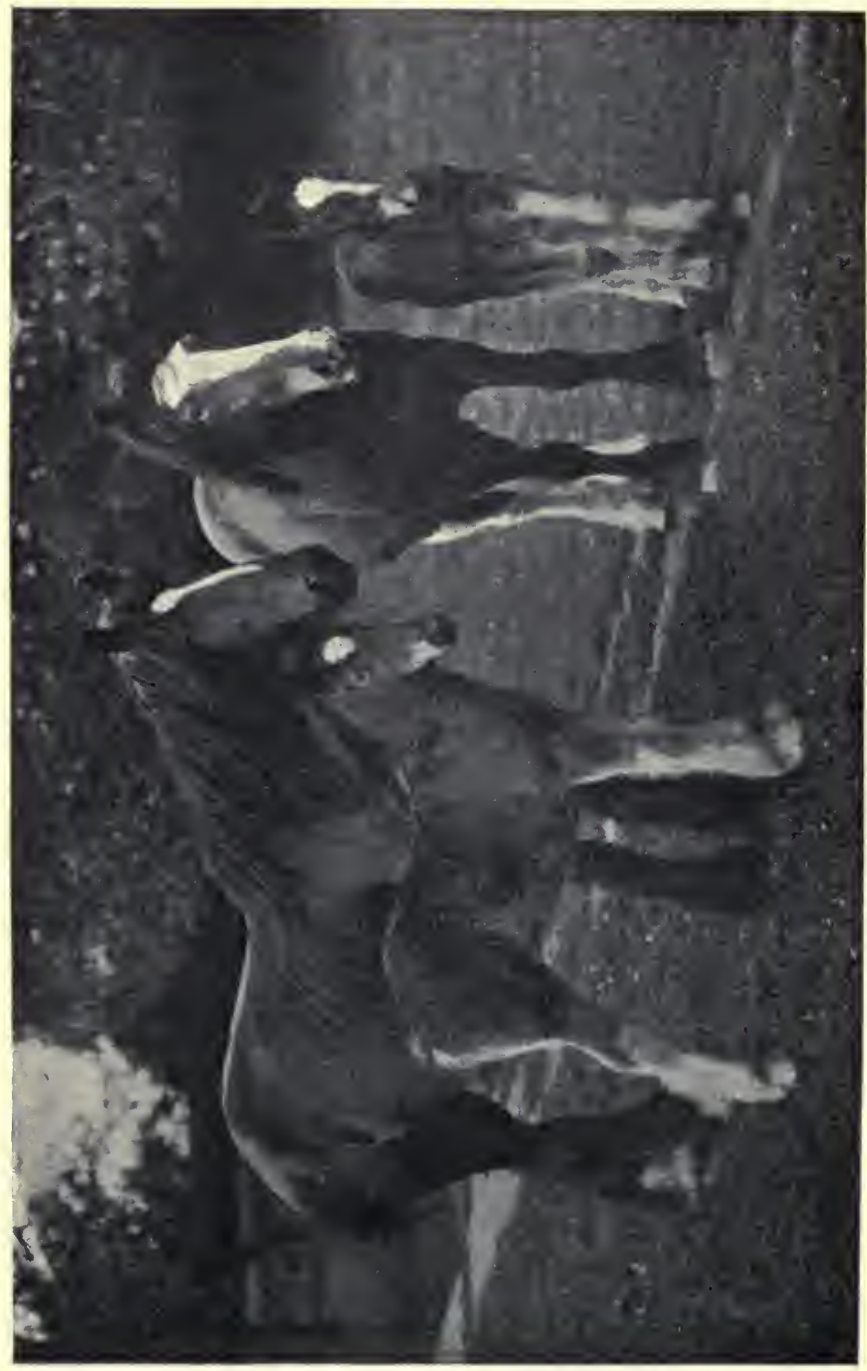


to the hand, you may be sure that the horse feels cold, and requires warmth.

Remember that a horse is naturally intended to walk or roam about plains or fields. So when he feels chilly he simply moves about, whereas when he is in a stall he cannot do this, and therefore he has no means of getting up his circulation.

A horse will require less food in a warm than in a cold draughty stable; it is better, however, to have a cold stable and plenty of air than a warm stable and foul air.

The stable should be well lighted, because this keeps the eyesight keen and good, so that a horse that is kept in a well-lighted stable shies less when he is at work.

The stable should be free from offensive smells, because bad smells and defective ventilation cause a horse to feel unwell, and then he becomes low-spirited and out of condition. Whenever a horse that is usually a good feeder refuses his food, you may be quite sure that there is something wrong with him.

The bedding should be sorted and dried every morning, and the stable flushed down with a plentiful supply of fresh water.

\section{Grooming and Feeding.}

To keep a horse in good health and in the best condition for working, every morning his 
skin should be well rubbed over with a hard water brush and curry comb. When a horse is out in the open, he will often roll on the hard uneven ground, and thus set up a healthy friction of the skin so necessary to health. He cannot do this in a stall, so we are obliged to use a hard brush and curry comb. This helps to keep the skin free from scurf and clean, and stimulates circulation and creates warmth.

The feet ought to be carefully washed and cleaned out every day, and your horse must never by any chance when he is in the stable stand in damp nasty slush or muck. If he does, he will soon get something wrong with his feet and in time go lame.

A horse ought to be regularly fed, the number of times a day, and the quantity of food depend on each horse, and the amount of work he has to do. Remember that a horse has a small stomach, and therefore he ought to be fed in small quantities and often, especially is it important that he should be fed early in the morning.

Generally speaking, the best "feed" for a horse when he is at work is bright-coloured, heavy, old oats; the oats ought to be crushed and mixed with chaff; then the whole, oats and chaff, damped with water. If you give the oats whole and not mixed with chaff, a horse will swallow many of them without properly masti- 
cating them or digesting them. Therefore mueh of the nourishing properties of the food are lost, that is, are not turned into flesh, musele, and bone, and this of eourse means waste and expensive feeding.

Whereas, if the oats are crushed and mixed with ehaff, the horse is obliged to ehew them and the chaff well together. This causes the saliva to mix freely with the food, and promotes digestion.

It is not what you swallow that of neeessity does you good, but what you digest. It is mueh better for the health and strength of your animals, and for your own well-being, to take a small quantity of well-digested food than a larger quantity of badly digested food.

You make a horse eomfortable for the night by "Bedding up," as it is termed-that is, you pile up around him and under him a good thickness of elean straw upon which to lie. After you have done this, give him a good armful of sweet, old, greenish-looking hay. The best hay has always a strong, sweet smell, and has a greenish look. When hay looks dark brown it shows that it has not been harvested in the best eondition ; in other words, that much goodfeeding quality has left it, and that there is very little nourishment in it.

Horses are very particular as to the water 
they drink; therefore, let it be pure and wholesome, and see that the bucket in which you carry it is quite clean. Soft water is the best. It is more easily digested, and not so likely to chill a horse. It has been found that if water is always left in the stable, where the horse can drink it when he likes, that he will drink less, blow himself out less, than when it is only given him occasionally at stated times from a bucket.

When you are driving a horse on a journey, and you come to a drinking fountain, let him have a few mouthfuls; it will refresh him greatly, especially on a hot day.

Experience has now taught us, that it is best to give a horse a little water before he feeds, and never wait until some time after he has finished his feed. In the summer some good green grass or clover should be given; this cools the blood and affords a change of diet. A carrot or turnip sliced up and mixed with the "feed" is very refreshing to a horse. Most horses are very fond of sugar, and, when they are fond of it, give them a few lumps each morning from the palm of your hand; then, as the delicate, scnsitive lips take the sugar, speak to your horse and he will soon get to know your voice, and thus you may train him to obey your will.

Wherever possible, give your horse a few weeks' run in the fields every year. This will 
add to his general health, strengthen his legs, and extend the number of years he will work for you.

In the winter, autumn, and spring, when your horse has been doing a lot of work, and seems listless and out of condition, a few split beans added to the food once or so a day may help him. But you must be very careful about giving beans. They produce a good deal of heat, and. unless used with the greatest care your horse's legs will begin to swell, "fill," as it is termed, in which case the beans will do more harm than good.

Some people use moss litter for bedding, but in the country, where manure is so valuable, this cannot be recommended. Very often moss litter contains seeds of weeds, so that when you place it on the land as manure, you may be sowing a crop of weeds, and no more deadly enemy has the farmer than weeds. When once they get hold of the land, it takes a long time and much money to get rid of them.

\section{How to Treat a Horse.}

There is a golden rule, "Be firm, but kind." If possible, never change your mind. Let a particular word and tone of voice always mean that you intend a horse to do a certain thing, and see that you are obeyed. If possible, never 
let a horse conquer you, because you will have more trouble next time. A horse soon learns who is master.

If your voice, rein, and heel fail to obtain obedience, then as a last resource use the whip. When you do use the whip, use it well, but when everything else has failed, and always remember this, for it is very important--keep your control; don't lose your temper. In your treatment of all animals be very patient, and closely observe the different dispositions of each.

Perhaps there is nothing that shows a good horseman more than his manner of holding and using the whip. A skilful ploughman - and very skilful work is ploughing-will work his team by his voice, with only the assistance of two slender string reins.

A good waggoner will seldom strike his horse. Why should he, when the big, beautiful creature understands and obeys everything said to him?

The human voice, when it is associated with confidence and affection, has a wonderfully calming effect on a horse. It will suceed when everything else fails. Therefore constantly talk to your horse. Before going up to him in his stable always speak to him first. While you are speaking to him, stroke his neck and nose gently. When you can manage it, put a lump of sugar in your pocket, and when you have a chance 


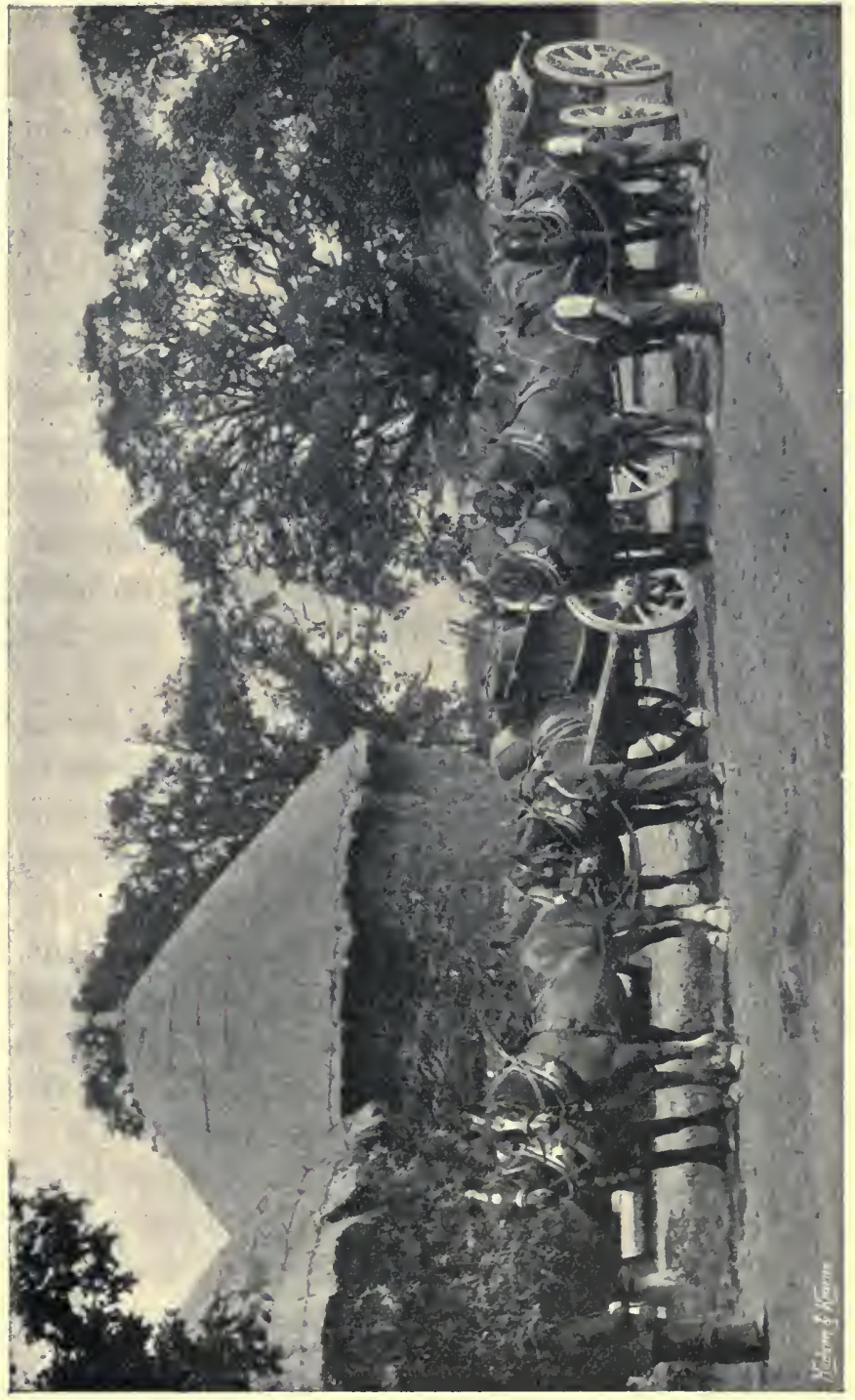

拿 
give it him, speaking to him at the same time. Associate everything you do with some word or tone of voice, and in a short time your horse will understand what you mean. Your horse will then regard you as a friend, and the kinder and more considerate and feeling you are, the more work he will do for you, and the greater the pleasure you will have in working him.

Many horses shy a good deal at objects they meet on the road. This mostly arises from nervousness, because the objects are not familiar to them. Therefore, to cure the habit, you must get your horse accustomed to what he sees, and so give him confidence.

If your horse pricks his ears, and shies at something he sees on the road, take him up to the object he has shied at; at the same time speak firmly but soothingly to him; this will soon give him confidence.

Of course some horses will shy, and jump about, all over the road, out of pure high spirits and from want of work. The only thing then is to sit tight, using your voice and judgment, till the ligh spirits have expended themselves.

Be careful never to stop a horse that is drawing a vehicle or load in the middle of a hill, except for a rest; and if for a rest, draw him across the hill and place a big stone behind the wheel, so that the strain on the shoulder may be eased. 
Unless absolutely necessary never stop a horse on a hill or in a rut, so that when he starts again it means a heavy tug. Many a horse has been made a jibber and his temper spoilt by not observing this rule.

Above all things, be careful of your horse's mouth. In riding or driving you ought only just to feel your horse's mouth. Your hands ought not to be rigid, like bars of iron, but they ought to give and take with every movement of the horse's head. Your horse's mouth then becomes delicate, alive, not hard and dead. In fact, try to cultivate what is termed light hands. Then if sympathy exists between you and your horse, you can guide him with hardly any movement of the reins or hands.

By driving or riding with light hands, the mouth becomes so sensitive that it feels, and is guided by the slightest movement of the reins.

If your horse has what is termed a "good mouth," he is much more valuable, because a good horseman gets so much more pleasure in riding or driving him. It is misery to handle a horse that is always pulling at you, with a mouth that feels dead. It is something like pulling against a stone wall. Such a horse loses half its value. These hard mouths, and, indeed, many evil habits are often caused by the heavy hand and rough methods of ignorant men in "breaking in " young 
horses. In nine cases out of ten the manners of a horse depend on the way he was treated when young.

To obtain good manners in a horse, which means that he does not shy, kick, bite, run away or jib, but moves along easily and brightly, answering to every movement of the rein and whip, and command of the voice, he must from the time he is born be treated kindly, but firmly, and never frightened.

Remember that a horse is naturally a very timid and sensitive creature, and therefore, when you break him into work, try to create in him confidence, but at the same time make him feel that he has to do what he is told.

The foal before it has left its mother ought to be handled, petted, spoken to, and got accustomed to the saddle, bridle, and harness.

If you wish the young horse to become a first-class and clever jumper, make some jumps in the field, which he will be obliged to jump before he gets his water and feed of corn.

It is a great mistake to work your horse much when he is young. He ought only to do very light work between the ages of four and five years. By the time he is five, he has probably stopped growing; his bones are set and hard, and his muscles strong and flexible. The year spared to him between the ages of four and five will 
probably enable him to work for many years longer than he would do if put to hard work before that time.

You have noticed how fond horses are of companions. How sociable they are. With some horses this sentiment is so strong, that if their stable companion be taken from them, they will fret, and for a time refuse to feed. If the companion that has been with a horse in the field be taken away, the solitary one that is left will gallop wildly about, neigh, and show every sign of unhappiness.

Therefore, whenever possible, let your horse have a companion.

\section{A FEW FACTS ABOUT ALL HORSES.}

You will now read of a few facts that are common to all horses.

In rising from the ground after lying down, a cow kneels on her fore-legs and lifts herself up by her hind-legs, whereas the horse tbrows out the fore-legs and raises himself on his hind-legs.

The teeth at the back of a horse's mouth are called grinders, the teeth in front are called cutting teeth or incisors. A cow has no front upper teeth, but only bare, hard flesh-a pad as it is called. She therefore, with her tongue, 
gathers off the grass, which is at once sent to one of the four compartments of her stomach. When this is full she generally lies down and pumps the undigested food into her mouth, and then by moving the jaws from side to side, her back teeth, or grinders, grind the food very much as corn is ground between the rough edges of the "mill stones" of a mill. When the food is thoroughly masticated in this way it goes into another compartment of her stomach, where it is digested in the usual manner. Now, a horse cuts the grass off with his front incisor teeth, very close to the ground, masticates it, and swallows it as we do our food. A horse has no pad as a cow, but six sharp cutting teeth in front, so that he can graze very much closer to the ground than can a cow.

Here is another important fact. Between the six incisor front teeth and the back teeth or grinders, the horse has a space called the bar, into which fits the bit that is placed in his mouth. If a horse had no such space as that, but teeth all round the jaws as we have, it would be a great cruelty, in fact it would be impossible, to place a bit in his mouth.

In the country it is most important to observe carefully everything that goes on around you, and then to try and remember accurately what you have observed. In this way you will 
probably learn more of the life about you than you would. from any number of teachers and books, no matter how good they are.

Just as each of us has a different disposition or character, so each animal has its particular character or disposition. And the more you treat each animal according to its own disposition the greater will be your power over that animal.

You will remember that at the beginning of this chapter you read, that before horses were tamed by man they wandered in large herds over wide and immense plains. Now this statement is borne out by observing the habits of your horses, especially of the young horse,- - the foal.

If horses lived in herds on wide plains, their principal weapons of defence and of escape from their enemies must have been their great pace and endurance in travelling. If therefore the young foal, almost directly it was born, could not have galloped fast, the enemies of the wild horse would soon have captured and killed all the young foals, and so, it would not have taken very long before the race of horses would have come to an end.

To give the young foal the speed that was necessary to preserve its life, it is provided from birth with very long legs, looking like a horse on stilts. And, if you observe a colt, you 
will see that within a few days of its birth it can gallop almost as fast as it ever can in its life.

There is a story told of a thoroughbred foal of about a month old, that once beat a trained race-horse over half a mile course, and thus won its owner a large sum of money.

The mother or dam of the foal was noted for her speed, and she had a jockey on her back, the mother beat the horse racing against her, and her long-legged foal kept up with her with ease.

Now, if the young foal had had a large stomach and been obliged to consume a large quantity of food to satisfy its hunger, as does a cow, it could not have galloped fast, and so would easily have been captured by its enemies. Thus it is that instead of having a large stomach like a.calf, the foal has a small stomach, and therefore needs constantly to go to its mother for food, and is satisfied with a few mouthfuls at a time.

Then look at the hard round hoof of the horse, how beautifully suited it is for travelling fast on hard plains. If a horse gets into a very boggy place, its hoofs sink in, acting as a kind of sucker, so that it requires a strong, muscular effort on the part of the horse to pull them out. Now, a cow or a bullock, owing to its having a slit between its two toes, can travel faster over a place deep in mud than can a horse. Owing to 
this fact, it is stated that mounted hunters have been overtaken and killed by fierce and enraged wild buffaloes.

Also notice how a young foal will lie down. It will stretch itself fully out. A calf, on the other hand, will curl itself round in as small a space as possible. You will read the reason for this in the chapter on the cow.

In these open plains there was little or no cover for concealment, nor was there any need for a herd of wild horses to conceal themselves. They trusted to escape their enemies by their speed and quick sense of hearing and eyesight, and not to the protection of concealment, as does the calf.

When a horse is alarmed it throws its head as high in the air as possible, as if desirous of obtaining the most extended compass of view. This is what it would naturally do on the open plains, for the farther away it could see its enemies approaching the longer notice it would get, and the better would be its chance of escape.

Take bucking, kicking, and shying. You must have noticed all horses when they are first turned out in the fields after confinement for some time in a stable, how they will gallop about, and with heads well down will kick and buck. You can at once understand that this would be the best plan for a horse to adopt to get rid of a beast of prey that had sprung upon its back. With 
some horses, the power of kicking and bucking is so great that they can get a saddle off their backs without breaking the girths.

Now take shying. Let us suppose a herd of wild horses trotting over a plain. They come across a thick mass of growing grass in which lies concealed a beast of prey. Directly they saw the slightest movement of the grass, their experience taught them to suspect that some beast of prey was on the move, and was about to spring. Then the horse that could swerve the quickest and furthest would have the best chance of evading the spring of the beast that hungered for its dinner.

These and many more habits that we observe in our domestic animals seem quite useless now, but you may be sure they were of the greatest use in preserving the lives of their wild ancestors before they were tamed by man.

The intense desire to live, that is present with everything that does live, caused these habits to be gradually acquired or adopted by the wild ancestors of the present animals; and these habits, continuing for countless years when they were in the wild state, became at last so firmly rooted,instinctive, as it is called-that they continue in the domesticated animals of to-day, of course to a very much slighter extent, although their need, for the purpose of preserving life, no longer exists. 


\section{ABOU'T CATTLE.}

\section{Wild Cattle.}

IN the last chapter you have read that it is stated by scientific men, who have given a careful study to the question, that the forefathers of the present domesticated horse, the wild horses, lived and wandered in herds over dryish plains; that they developed their quick hearing, their keen eyesight, great staying powers, and high speed in their endeavours to escape being captured and eaten by their enemies that lived around them.

Now, if you observe and consider the natural habits and bodily formation of our domesticated cattle, you will come to the conclusion that their wild forefathers, the wild cattle, could not have lived on open, dry plains, but that they must have lived in districts wet and marshy, which were probably well studded with trees.

As one proof of this, compare the foot of a horse with the foot of a cow. The foot of a horse is round,-it is really the nail of the third 
toe lengthened, hardened, and rounded,--hard, all in one piece, and so just suited to galloping at a great pace over dry and hard land.

The foot of the cow, on the other hand, is really formed from two toes, with a slit between the toes. In consequence of this slit formation, the cow has no difficulty in walking through marshy land. But the foot of a horse will sink into marshy land, and as it acts like a sucker it can only be withdrawn with a great muscular effort.

As you know, on level, hard ground, a horse can outpace a cow or bullock with the greatest ease. But race a horse and a bullock over boggy land, and the bullock will probably beat the horse.

Travellers tell us that, wherever wild cattle are found, they will not of their own accord wander far away from woods, and you must have noticed how the cattle around you love to stand knee-deep in water, and under the shade of trees.

You have read that a wild horse trusted to his speed to escape his enemies; but the wild cattle trusted more to their horns and great strength of neck to defend themselves against their foes. It would take a very hungry, very desperate pack of wolves, or other beasts of prey, to attack a herd of wild cattle, when at bay, with their 


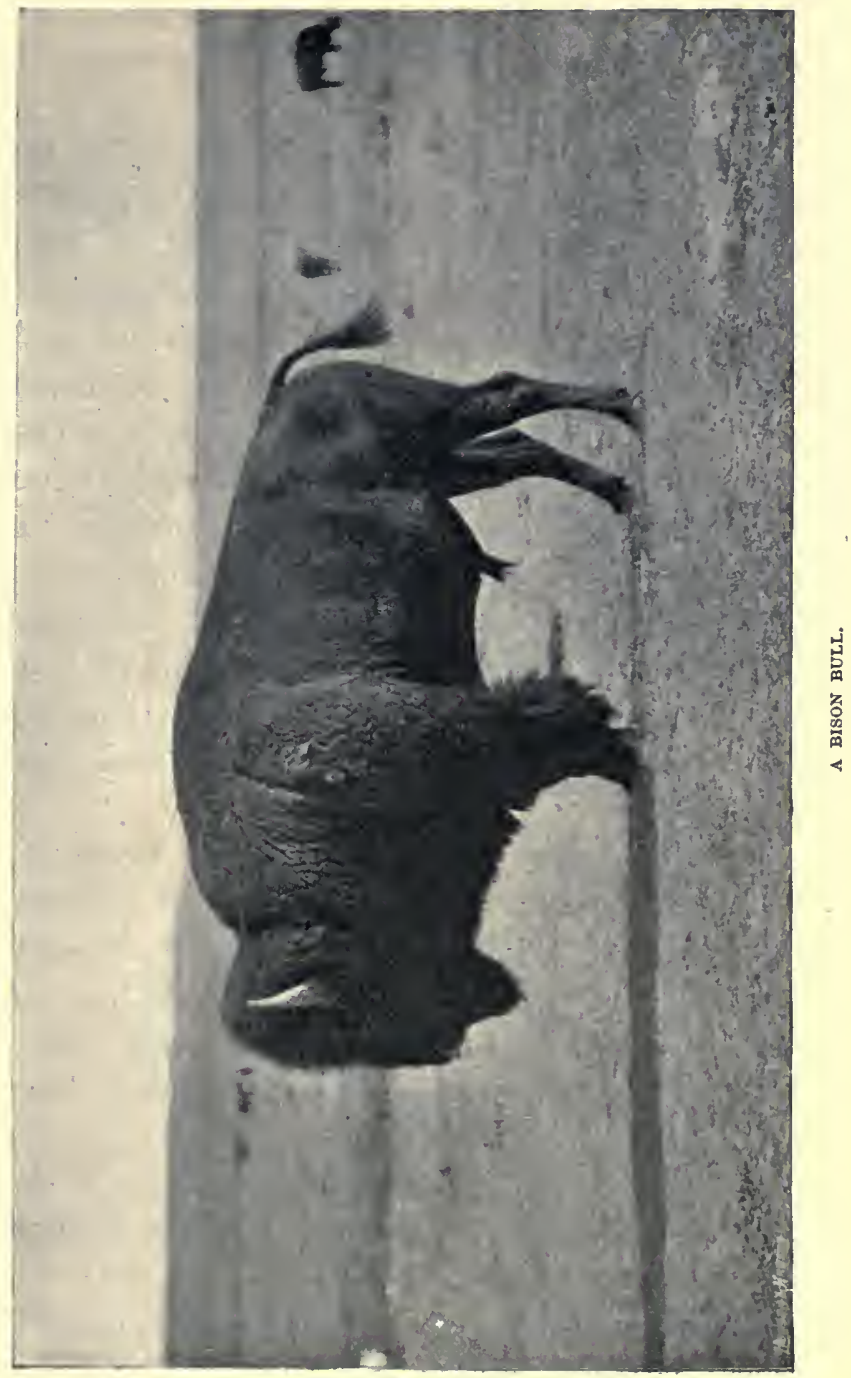


sharp horns and stout neck as weapons of defence.

Men in the old days took advantage of this strength of neck and horn to use the bullock for doing the work of the farm instead of using horses. In the dreamy, sleepy, hot East, bullocks are still in very general use, and to-day in parts of Sussex, pairs of bullocks can be seen harnessed with a very old-fashioned form of yoke, - a yoke which fits on to the nape of the neck, - with which the animals drag the plough that ploughs the fields. In France the yoke is fastened to the horns and brow, so that the horns, brow, and neck bear all the strain of carting heavy loads and dragging. the plough. This will show you the immense strength of a bullock's head, neck, and horns.

A bullock or cow is a very patient beast, not nearly so nervous or given to alarms as a horse.

Speed, and alertness, and a very sensitive nature, were necessary on the part of the wild horse to enable it to escape its enemies, and so this nervous disposition has been handed down, and is inherited by the horse of to-day.

The wild cattle, on the other hand, knew that their best weapon of defence was their stout, strong neck and powerful horns, and that they could defend themselves best by standing together at bay, with their heads down, and calmly await- 


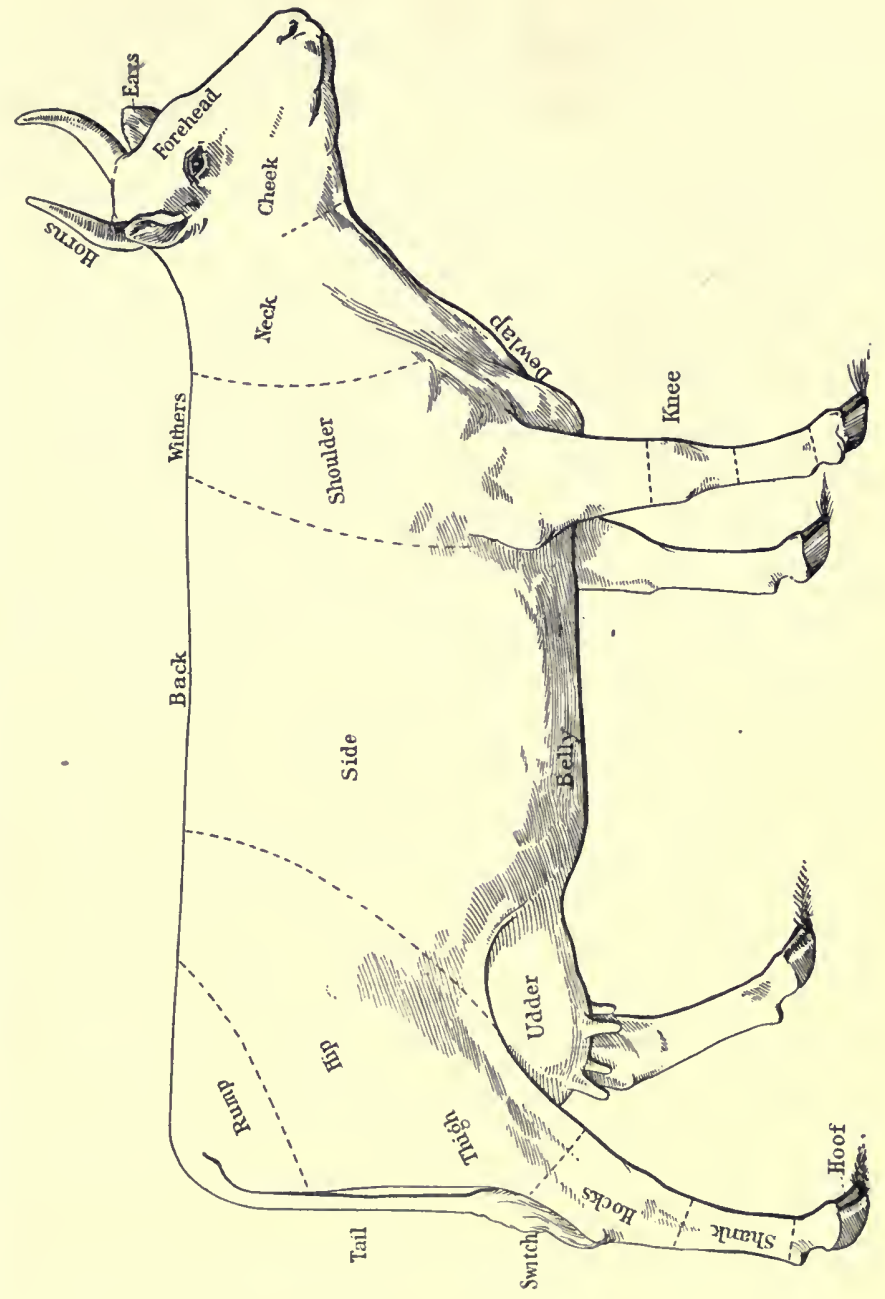


ing the attack of their enemies. This disposition has been handed down to the domestic eattle, and is seen in the patient, slow-moving bullock and cow.

A horse, as you have read, has a very small stomach, and so can only take in a small quantity of food at a time.

When the wild cow drops a calf she conceals it in any good hiding-place that there is about as a protection against any beasts of prey. Having done this, the cow goes off and fills her udder full of milk in the manner you have just read, when she comes back to give her calf its meal.

As the cow only makes a sufficient quantity of milk to fill its calf's large stomach and satisfy its hunger, perhaps twice a day, the calf must take in a large quantity of milk at one meal. In consequence of this, it would have small chance of escaping its enemies by speed as does a foal, which has a small stomach and requires food often and in small quantities. Therefore, to obtain the large quantity of milk food that its young requires, the cow most cleverly conceals her calf while she wanders off, it may be for hours, to graze off a sufficient quantity of herbage to turn into milk with which to fill her udder.

Of course, when the cow mother is near her calf, she will defend it to the death against any 
beast of prey that may attack it, and her horns, backed by courage and strength of neck and head, are very effective and terrible weapons of defence.

You can now see why a wild cow has a large udder that contains a large quantity of milk.

Man has taken advantage of this natural storage of milk, and has turned it to his own uses.

Moreover, by careful feeding, housing, and attention generally, and by taking away the calf from its mother and rearing it by hand, and specially by breeding from those cows which give naturally the greatest flow of milk, man has very considerably increased the quantity of milk given by the cow of to-day, as compared with the quantity given by her ancestors in their wild state.

You will notice, when a foal lies down it stretches itself out at full length with no effort at concealment. But a calf will always curl itself up, as if anxious to conceal itself.

Then you must have observed that when a horse is alarmed it throws its head as high as it can, as if it wanted to get as extensive a view as possible of the approach of the enemy. But down goes the head of a cow if she is alarmed, as if she were looking for the approach of her enemy amidst the trees. 
So, from the formation of a cow, her foot, her power of giving large quantities of milk at one time, the habits of herself and her calf, it is thought that the wild forefathers of our present domesticated cattle lived amidst marshy ground thickly studded with trees.

Farmers, on the one hand, have so bred some varieties of cattle, that most of the food that they eat is turned into a large quantity of milk; on the other hand, farmers have so bred other varieties of cattle, that most of the food that they eat is turned into flesh, good beef for the butcher.

\section{Beef Cattle.}

The varieties that make the best beef are the Herefords, Devons, and Scotch polled.

The Herefords, that can be seen in the districts around Hereford, are small and compact cattle, and are easily fattened. They are mostly red in colour, and can at once be distinguished by their white faces and a wide band of white along the back and beneath the carcase.

The Devons.-The farmers on the rich growing lands of North Devon have produced a very pretty breed of rich red and well-shaped cattle. Their limbs are light and body rounded, the head light and tapering towards the muzzle, their horns have a beautiful curve and are of 


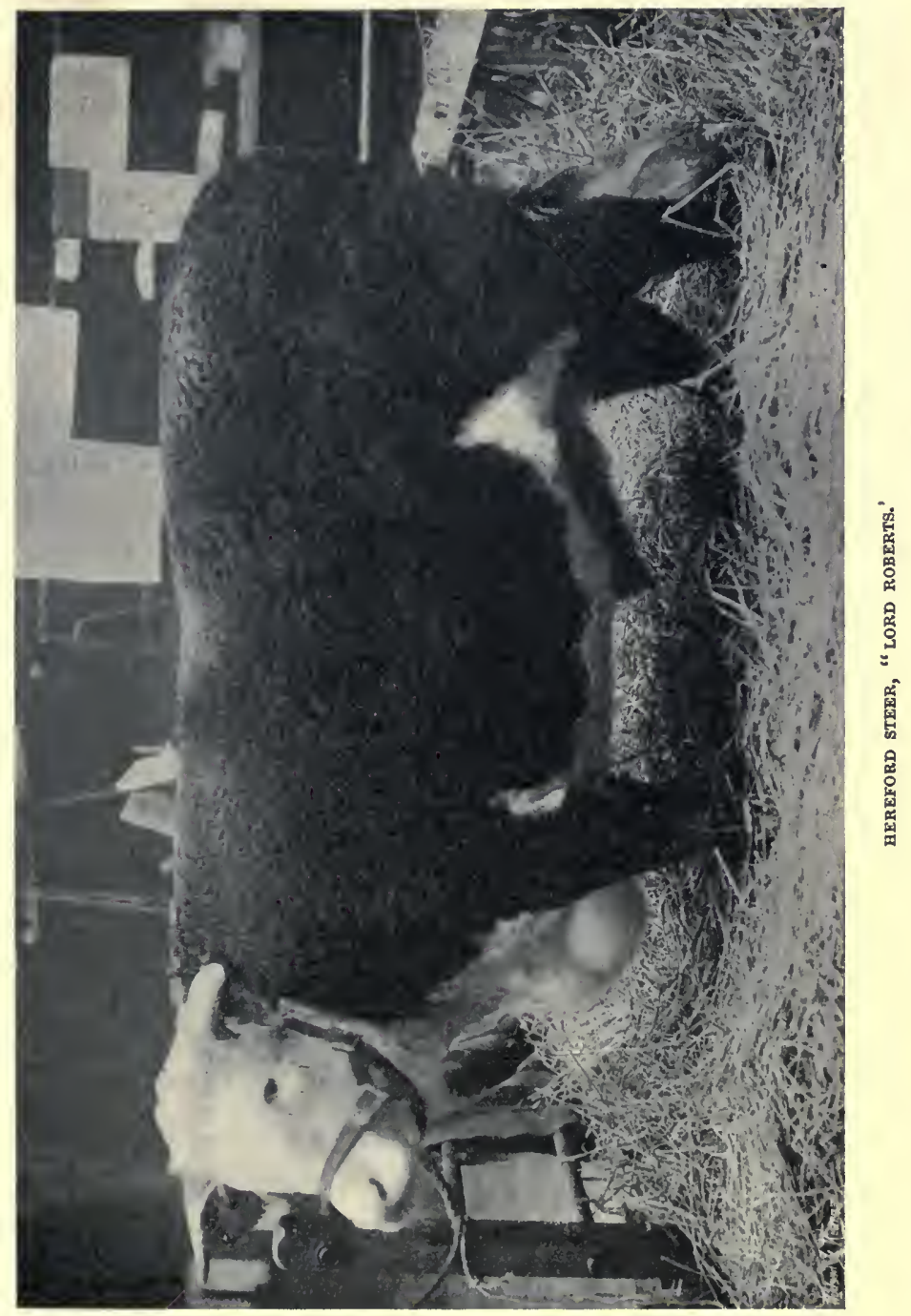


a creamy colour. There is no more perfect outline in cattle than a well-bred, averagely-fattened Devon. Some of the Devon cows are fair milkers. Unfortunately, in fattening they tend to produce more fat than is needed by the butcher.

Scotch Polled.-The Scotchman, with his usual cleverness and foresight, has bred the prince of animals that is killed for beef.

Perhaps the Scotch farmer, not having many populous centres to which he could send his milk, has devoted his attention solely to producing good beef, and well has he succeeded, for Scotch beef has the best reputation, and fetches the highest price of any beef on the market.

So careful for generations has the Scotch farmer been to breed only from those animals that looked like making good beef, that the Scotch Aberdeen Angus cattle produce very little milk when compared with the good milkers.

\section{Milk Cattle.}

Just as there have been bred cattle for the express purpose of fattening well and readily, on the smallest quantity of food, so there have been bred cattle for the express purpose of giving large quantities of milk, and for making milk that is rich in butter, and for making milk that is specially. suited for the manufacture of good cheese. 


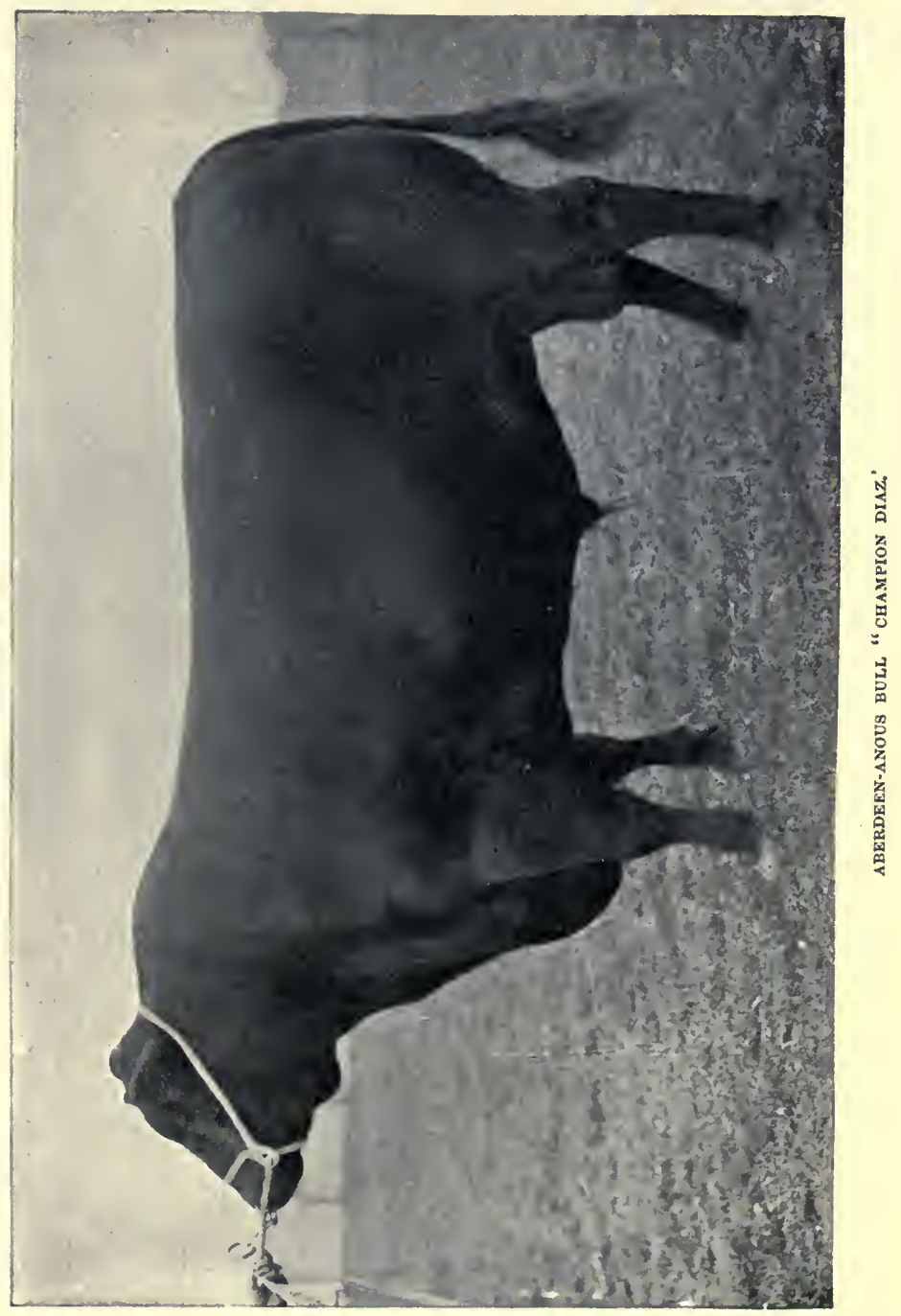


For a cow to be a large milker, she must be capable of consuming a large quantity of food, and turning it, not into bone and flesh, but principally into milk.

The shape best suited to produce this result is a cow with a light forehead, and deep from the back to the region of the udder. Of course a large and well-carried bag or udder, with free milking teats, is a necessity.

Ayrshire.-The soil in the county of Ayrshire, in Scotland, is of a heavy clay nature, which would be injured by the tread of a heavy cow. So to meet this condition, the farmers of Ayrshire have bred a light or medium cow, but a cow that will give a plentiful supply of milk, and a milk that will make a first-rate cheese.

Just as the Aberdeen Angus breed, having been bred solely for the purpose of making good beef, are poor milkers, so the breed of the Ayrshires, having been bred solely for the purpose of giving a plentiful supply of milk, are poor fatteners.

The Aberdeen Angus cattle are good fattening cattle, bred at the expense of milk.

The Ayrshires are good milking cattle, bred at the expense of beef.

The colour of the Ayrshire is generally red and white, or brown and white.

The Jersey.-In one of the Channel Islands, the island of Jersey, there has been bred a 


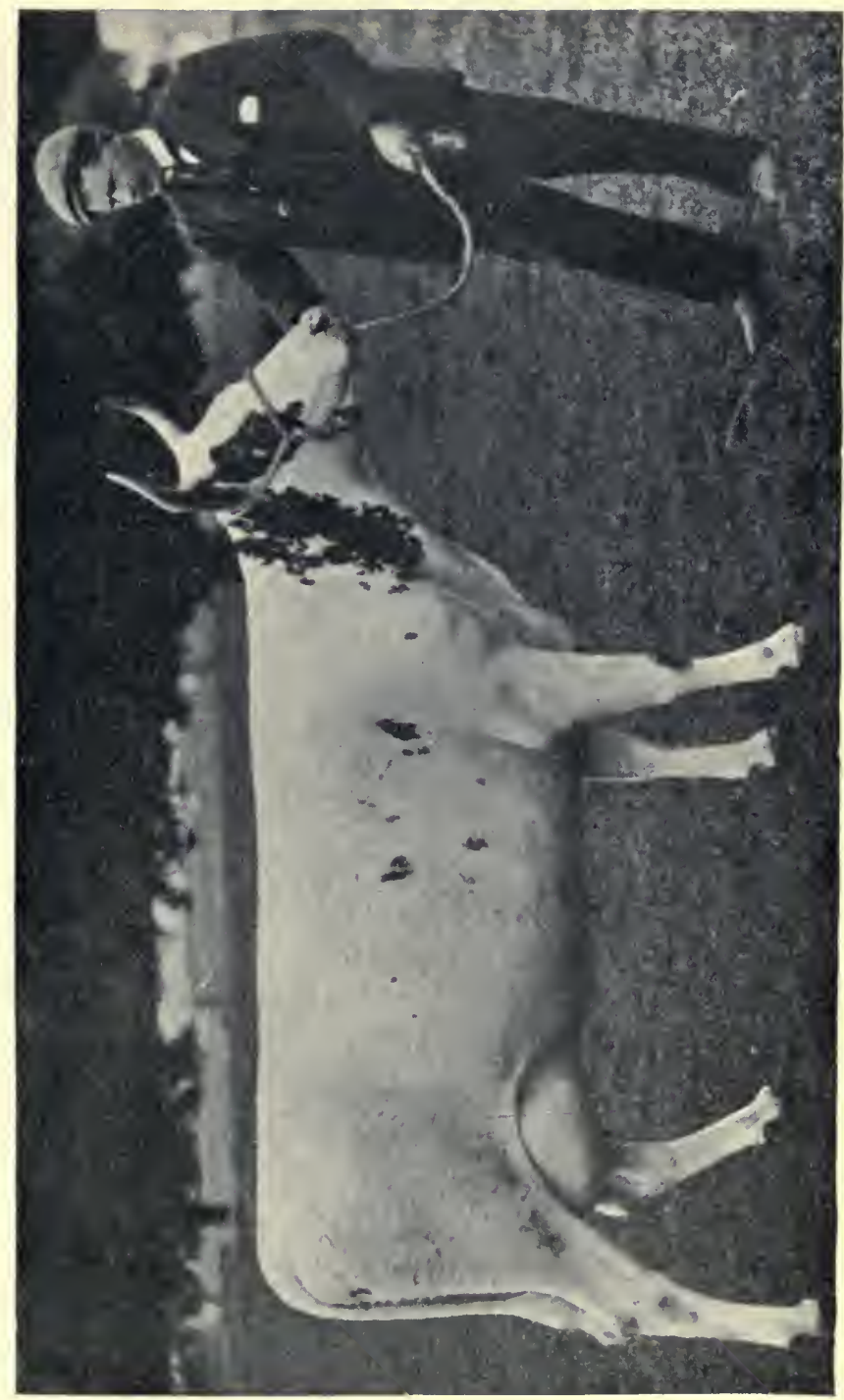

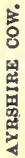


beautifully-shaped and graceful cow, a cow that gives a supply of milk rich in cream and of an exquisite flavour.

The Jersey cattle are like deer in appearance, with limbs light, head fine and thoroughbred, and muzzle light, with tongue, and roof of the mouth black. Perhaps there is no breed of cattle so much admired for grace and good looks as a herd of pure-bred Jersey cattle.

Owing to the care that the breeders of the Jersey cattle have taken to keep this breed free from mixture, the Jersey cattle are probably the purest bred cattle in the world.

The milk of the Jersey cow is specially rich in making butter. Whereas it requires three gallons of the ordinary milk to make one pound of butter, it only requires two gallons of milk of the Jersey cow to make one pound of butter, and the butter that is made from this milk is most delicious.

As with the Ayrshire, so with the Jersey cowshe will not fatten. So, if a Jersey cow from any cause does not give a paying quantity of milk, she is practically valueless, because she cannot be turned into profitable beef.

The Guernsey.-In another of the Channel Islands the breeders have bred the Guernsey cow. This cow is larger in size than the Jersey and fattens more readily. She also gives milk 


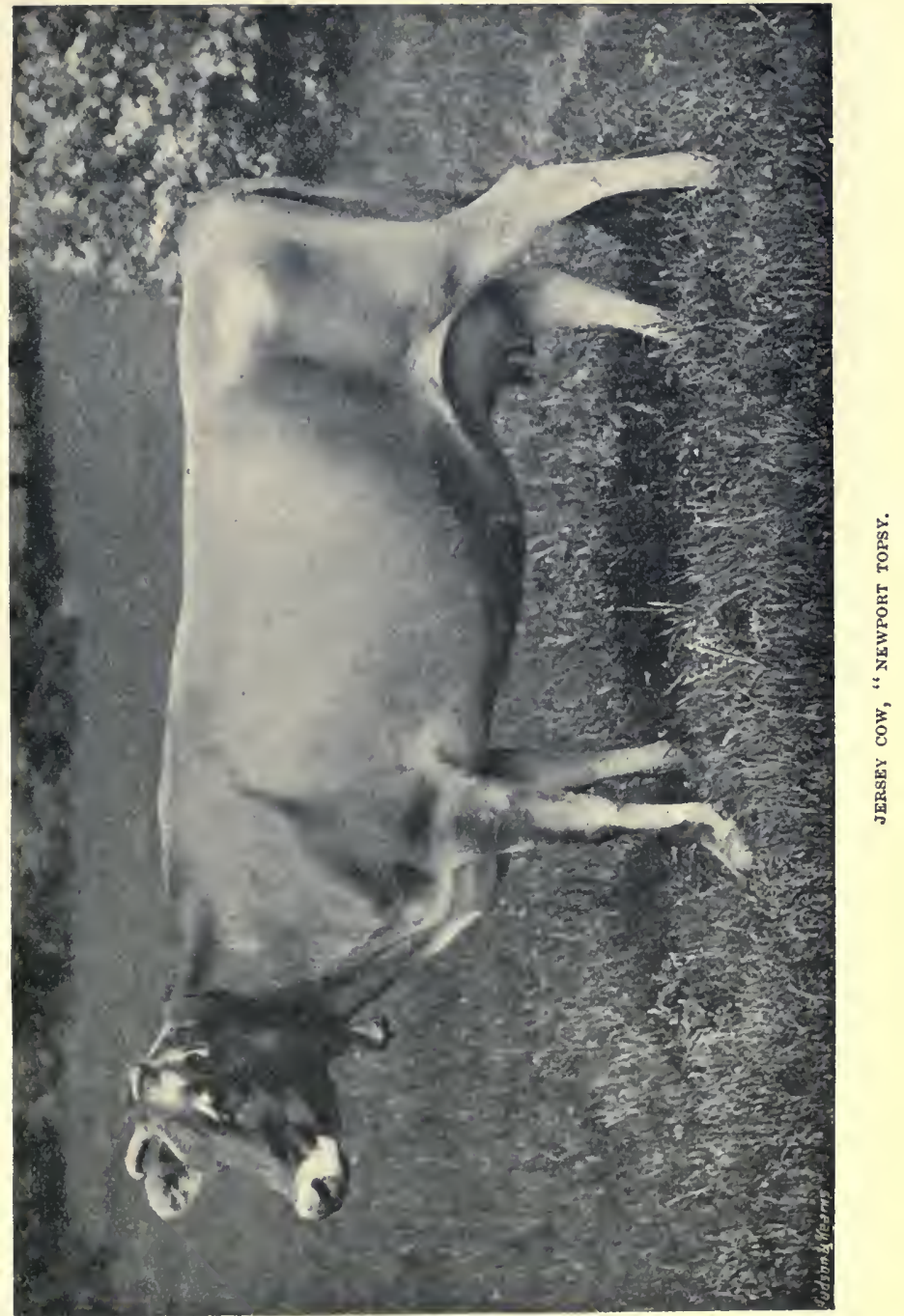


rich in butter fat, and is of a light yellowish red colour mixed with white. Her muzzle is flesh coloured, and there is an orange colour round the eyes, inside the ears, and at the back of the udder towards the tail.

The Shorthorn.-You have read that certain varieties of cattle have been bred for the express purpose of making large quantities of milk on the smallest amount of food, and that certain other varieties of cattle have been bred for the express purpose of making the finest quality of beef on the smallest amount of food.

But it was necessary for the well-being of the general mass of the farmers that they should possess a breed of cattle that would combine good milk-making powers and good beef-making qualities, and whose young would come to. maturity early.

If, for instance, the farmer found that one of his cows was not giving the quantity of milk that she should, in order to make her a profitable animal, it was necessary that she should be easily converted into beef, at the smallest expense. It was also very important that the general farmer should possess a breed of cattle that, according to the requirements of the market around him, he should be able to convert at the earliest possible age, either into profitable milk makers or into profitable beef makers. 


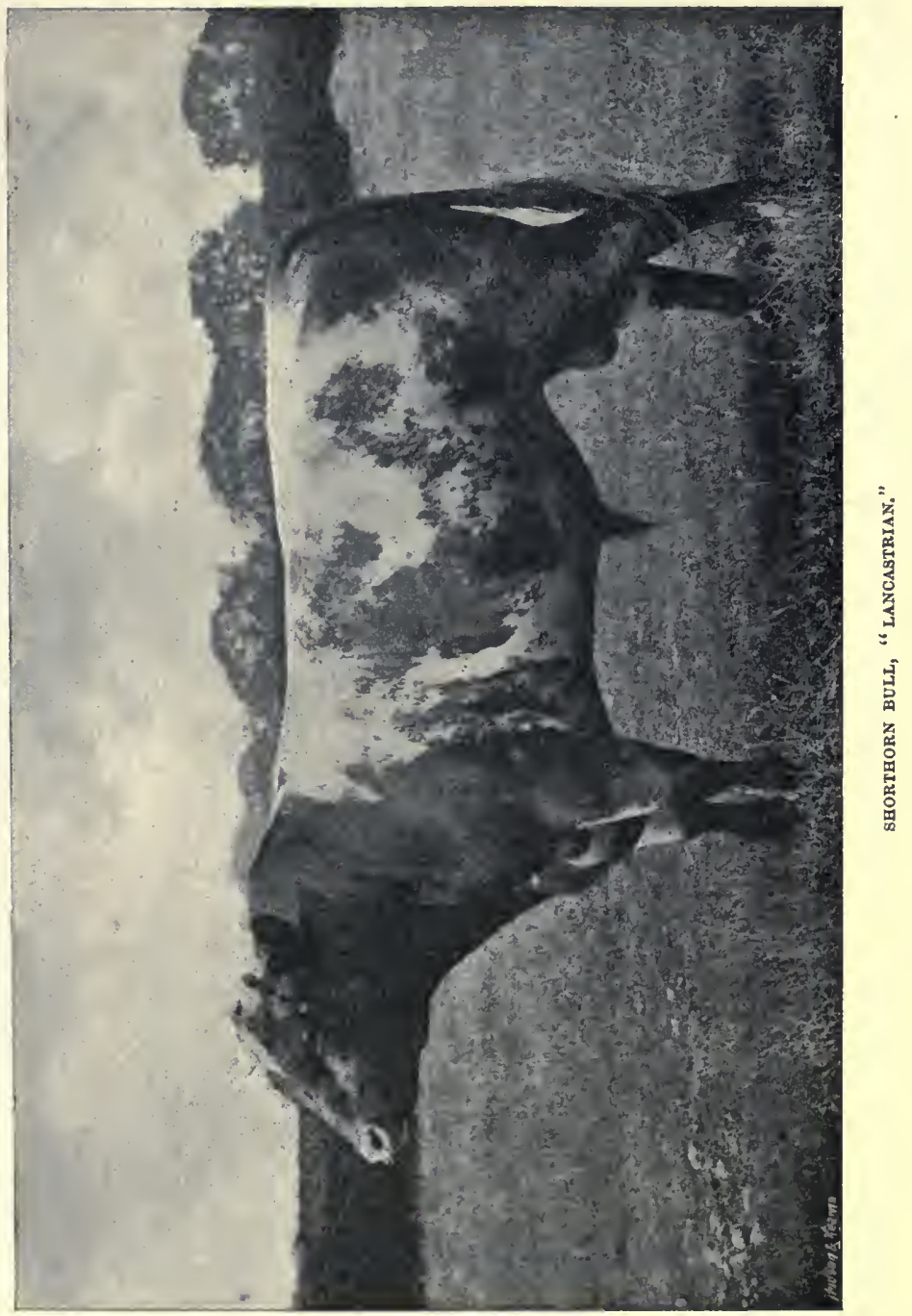


It was also important that this breed of cattle should do well on all classes of land, whether on light land, medium land, or on heavy clay land, and also should thrive in every variety of climate of the United Kingdom-North, South, East, West.

To satisfy these wants the breeders have produced the shorthorn.

The shorthorn is a breed of cattle that combines good milking powers and good beef-making qualities, that crosses profitably with almost every other variety,-especially the Aberdeen Angus, - and whose young become profitable at an early age. The shorthorn lives and thrives on any class of land, and in almost every variety of climate, that exists in the United Kingdom.

If the farmers require a plentiful supply of rich milk, the shorthorn will supply that want. If the farmer requires to fatten and not to milk, the shorthorn will do that. If the farmer wishes her calf to be turned into veal at the earliest date the calf of the shorthorn will satisfy his need.

In sunshine and rain, amidst the cold east wind, and the warm, wet west wind, on heavy land and light land, whether to graze in the field or to be chained in the stall, the shorthorn is equal to it all. Therefore we need not wouder that the shorthorn is the most popular, and is more widely bred and kept than any other breed of British cattle. 


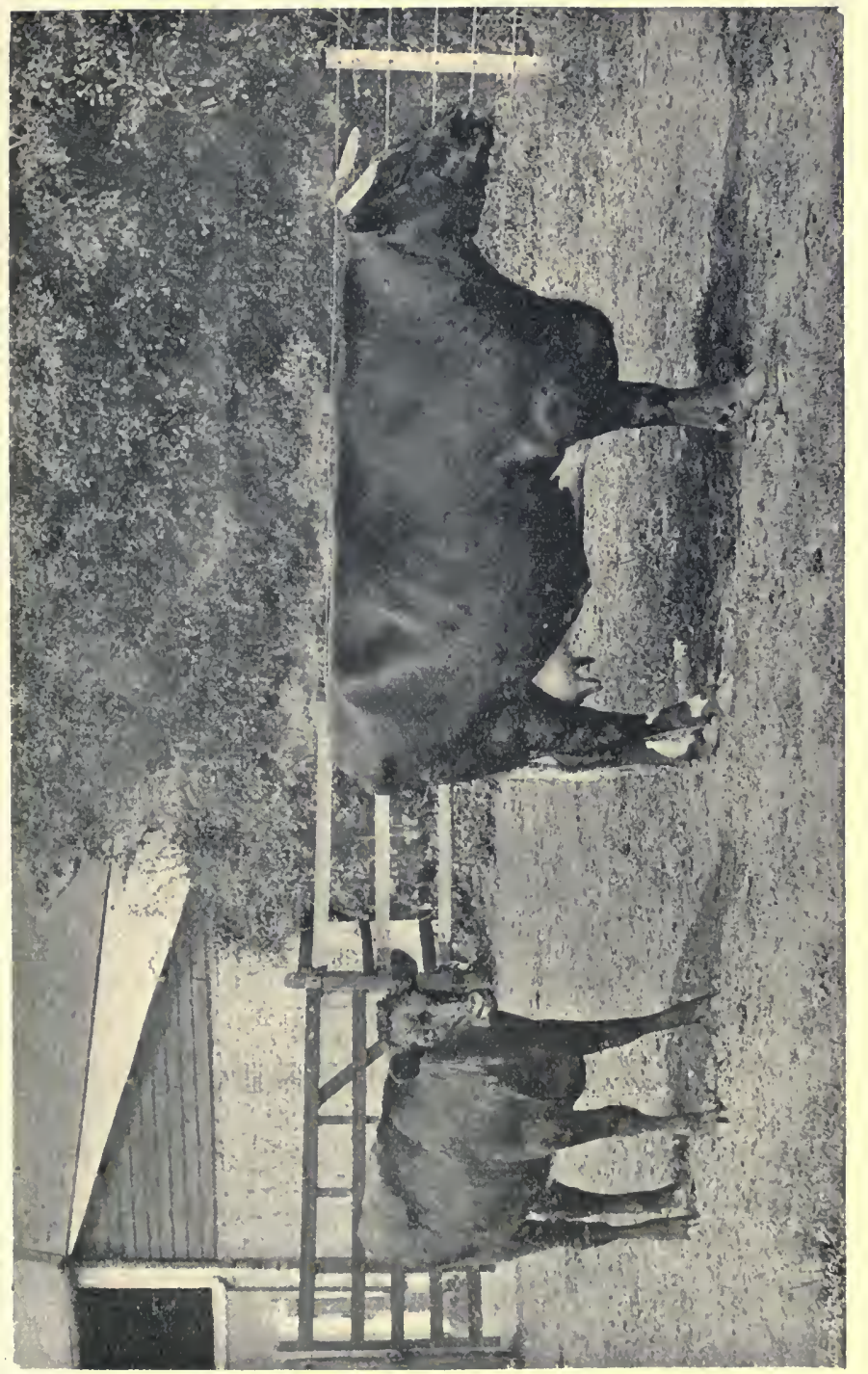

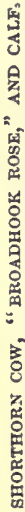


The shorthorn is level from the neck to the tail-in some cases as level as a table-deep from the hip to the udder, light in the fore-quarters, wide at the shoulder top. The shorthorn treads along lightty and gracefully, carrying her wellbred head high, and 'with pride.

Don't forget that this profitable breed of shorthorn cattle has been reached by breeders, first of all knowing what they require, that is to say, knowing their own mind; and then by only rearing the calves of those mothers which approach the nearest to the requirements of the breeders. In other words, the shorthorn has been brought to the useful breed it is, by accurate observation, and then careful selection and preservation.

Remember, you can all do a great deal to improve the milking powers of your herd of cows, or of your one cow, by only keeping and rearing the calves of those mothers which have yielded you a plentiful supply of milk.

This of course means keeping careful record of the amount of milk that each cow gives each day; and this naturally means taking trouble. But nothing successful has ever been accomplished, whether in the country or in the towns, without hard work and taking trouble.

*All painstaking and wise work will in time grow its crop of corn. All slovenly and ignorant work will in time grow its crop of weeds. 


\section{Milk.}

A young calf has to grow, that is, to make muscles, fat, bones, horns, hoof, and hair. If the calf is left naturally with its mother, it builds up all this and grows on milk as its only food. Therefore you must come to the conclusion that milk is a perfect food, specially for young and growing things. This conclusion of yours is borne out by scientific men, who by different methods have carefully analysed or examined milk. And they will tell you that milk is made up of three principal parts, namely fat, curd, and ash.

The fat of milk is really the butter of milk, and supplies fat to the animal and so keeps it warm.

The curd of milk, from which cheese is made, supplies the animal with muscle and lean meat.

If you dry up a quantity of milk you will find that there is left behind a very little solid matter or ash. This ash the young animal requires to build up its bones, and make them strong and elastic.

So you see milk gives to the young animal fat and warmth, muscle and lean meat, forms bones, hoof, and horns, and grows hair.

There is nothing that requires more care, cleanliness, and sweet surroundings and an even 
cool temperature than milk, cream, butter, and cheese.

Milk takes up strong smells very readily. If you stand milk in a room smelling strongly of any powerful smell, say onions, salt fish, or paraffin, the milk will soon absorb the smell, and the butter that is made from it will smell and taste in like manner.

If butter is made in a proper manner and amidst sweet surroundings, it will have a sweet, pleasant smell, but if you allow it to remain in an unclean, badly smelling place, it will very soon absorb, and give off an unpleasant smell.

Not only evil smells and dirty surroundings affect milk, and all that is made from it, but what the cow eats will affect the flavour and smell of milk and butter.

A cow grazing on well-drained pasturage, where there is growing a variety of nourishing grasses and clover, and where she can obtain a sufficient supply. of pure water, will give a wholesome milk, rich and sweet to the taste, and a milk that will make a butter strawlike or primrose in colour, and of a good flavour. But a cow fed on mangels and straw will produce a butter pale and tasteless, and looking like lard.

And if a eow is fed largely on Swede turnips, the strong-smelling oil that exists near the stem or the neck of the root, entering the cow's blood, 
will affect the flavour of the milk, and of the butter that is made from it.

So you can see at once that, if your cow is to give sweet-smelling, nicely-flavoured, rich milk and butter, the greatest care must be taken to make all her surroundings as clean and as healthy as possible. Also, the pasturage and food that the cow eats must be of a nature that will give good rich milk, and that will not taint either the milk or the butter.

\section{How to Treat a Cow.}

The cow herself, and this is most essential, must be kept healthy, and free fiom disease, and treated with the greatest kindness and consideration.

Many a cow has been ruined as a milker, because she has been roughly handled while milking, or been milked by one without experience of milking, or by one whose hands are rough and hard, and who has not that delicacy of touch that tempts a cow to give with pleasure and ease all the milk that she has made.

The cow house must be warm, well ventilated and lighted, and free from draughts, it must be well drained and built on a dry foundation, and must be situated so as to catch as much of the winter sun as possible. When she is fastened 
up, each cow must have plenty of room to move and lie down.

An abundance of fresh air and light, freedom from draughts and nasty smells, even temperature, suitable aspect, and dry foundations are the health principles that ought to be observed in building a "tying house," or cow house.

There is a terrible disease that it is feared is very prevalent amongst the milking cows throughout this country,--a disease called tuberculosis, and it corresponds to consumption in the human being. Undoubtedly this disease has been caused in the past, and is being caused in the present, by not observing the great health principle of sufficient light and ventilation, sensible drainage, absence of draughts, and a wise and experienced method of feeding.

As with us, so with a cow, when her strength and health are feeble she is liable to catch any disease there may be about; whereas, if her strength and health be vigorous she is much less liable to catch disease. In other and more accurate words, - the disease germs have a much better chance of st ttling in a cow low in condition, and beginning their life-work of ill-health and destruction, than would be the case in a cow that is vigorous and in good health.

It is necessary to repeat, because it is so important, that if you wish your cows to be 
business will take every opportunity of turning his cows out in the fields during the winter for as long a time as the weather will permit.

It is not generally done, but it adds considerably to the health of a cow, and therefore to her supply of milk, if every day during the winter, when she is tied up, she is curry-combed or brushed over with a rough brush and her body kept clean.

\section{To make Butter.}

The butter of the milk, called butter fat, floats about in small globules in the milk itself, and these are called cream globules. So tiny are these small globules, that it takes 2000 of the largest of them and 20,000 of the smallest of them, placed side by side, to cover an inch.

Cream is really highly condensed milk, rich in fat, and when you make butter your great object is to isolate or separate these fat particles or globules from everything else in the milk.

You must first of all obtain as many cream globules from the milk in as short a time as possible.

There are two methods of doing this-the old and the new. The old method is as follows. You take the warm milk from the cow, its temperature being then about 96 degrees, and you take it to a cold dairy, and place it, "or set 
it," in shallow vessels. To cause the cream to
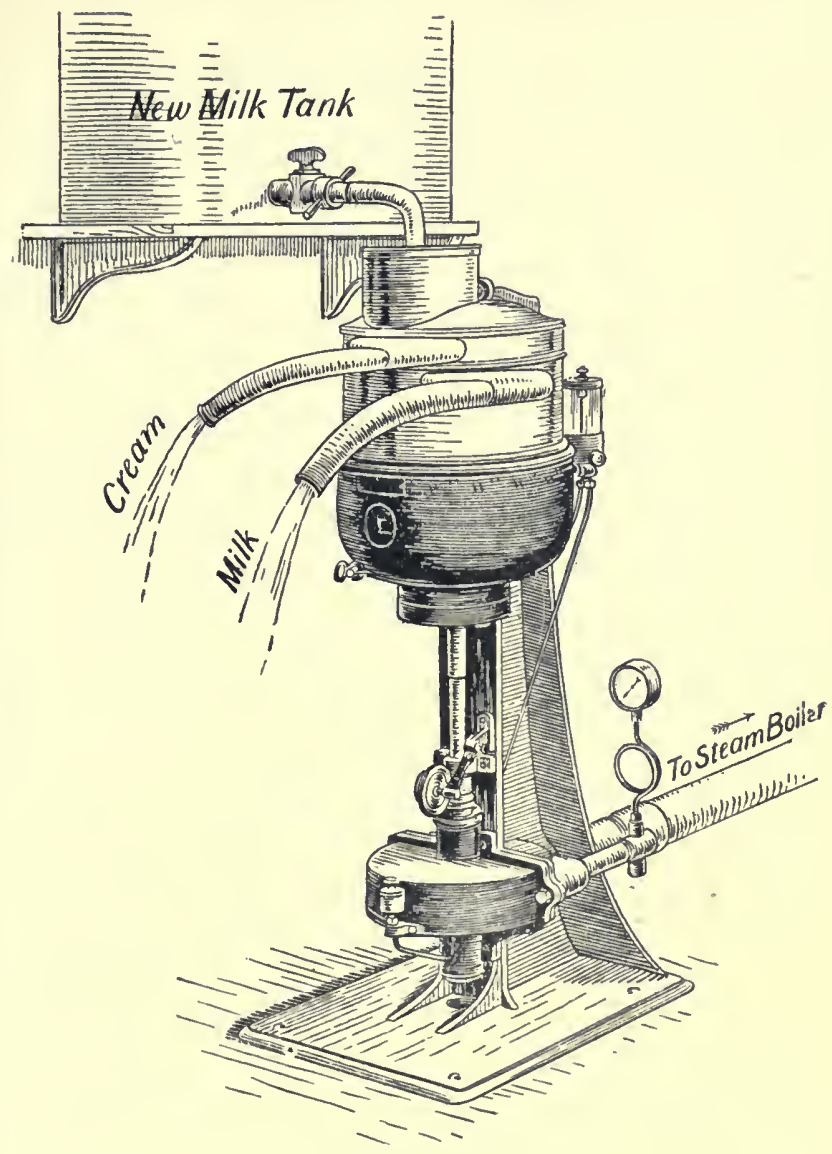

THE SEPARATOR.

rise as quickly as possible, these shallow vessels are themselves placed in cold water. 
As these cream globules are lighter than the milk, they naturally rise and colleet together in a condensed mass on the surface of the milk. When the cream has fully risen to the top of the milk, it is skimmed off and placed in small cream vessels to allow it to, what is termed, "ripen," that is, till it is in the most suitable condition for making butter. The moment of ripening must be learnt from your own experience.

The new method. In large dairies there is used a machine called a cream separator; the new milk is run into a part of the separator which revolves at a great speed, this rotary motion causes the watery particles, which are the heavier particles of the milk, to fly into an cuter compartment of the separator, and from there it runs out by a tap as separated milk. The cream globules of the milk, being lighter than the watery particles of the milk, are at the same time forced into an inner compartment of the separator, and from here it is run out by a tube as cream. So the separated milk runs out of one tap, while the cream runs out of another.

'The separator extracts 92 to 98 " per cent. of cream, whereas the setting in shallow vessels extracts only 80 per cent. of cream. The skim milk, however, left after skimming the cream from the milk set in shallow vessels, is more 
valuable, because there is more cream left behind than the separated milk obtained from the separator. This fact the farmer has to take into consideration before he decides on which method to adopt.

At the same time, it should be borne in mind that instead of having to keep the milk 24 hours before it is "skimmed," as is the case when it is placed in shallow vessels, tit can at once be placed in the separator and the cream extracted in a very short time.

This is an advantage, because there is less chance of the cream taking up any smells or dirt that there may be about, and less chance of its being affected by the weather. Moreover, the cream from the separator is more uniform, and therefore makes a more uniform quality of butter.

Uniformity of quality is essential in supplying the large modern markets.

When the cream is ripened, that is when it is in the best condition for making butter, it is

\section{Churned.}

The object of churning is, by violent concussion, to break up the fatty butter globules of the cream, mix air with them, and turn them into small grains of butter about the size of wheat grains. 
Although nothing but cream or fat is supposed to be placed in the churn, there still remains a quantity of milk mixed with the grains of butter ; this buttermilk must be drawn away. This is done by adding a supply of fresh water while the butter is being churned. The water has the effect of washing away all the milk that surrounds the butter grains, and which is allowed to escape from the churn by means of a tap. When the stream from the tap runs quite clean, you know that the water has done all that it can to remove the buttermilk.

The butter grains must then be removed from the churn and worked by hand. They are worked by hand in order to press them into solid butter, and in doing so press out any buttermilk that may still be left.

Remember that butter is a very sensitive substance, and that there are very few hands suitable to press these butter grains into solid butter. The reason of this is, that there is constantly coming away from the human hands an insensible perspiration, which affects the butter, making it greasy.

Therefore, all sorts of implements--called Scotch hands, butter shapes, scoops-liave been invented, so that in removing the grains from the churn, pressing the grains into solid butter, forming the butter into different shapes or 


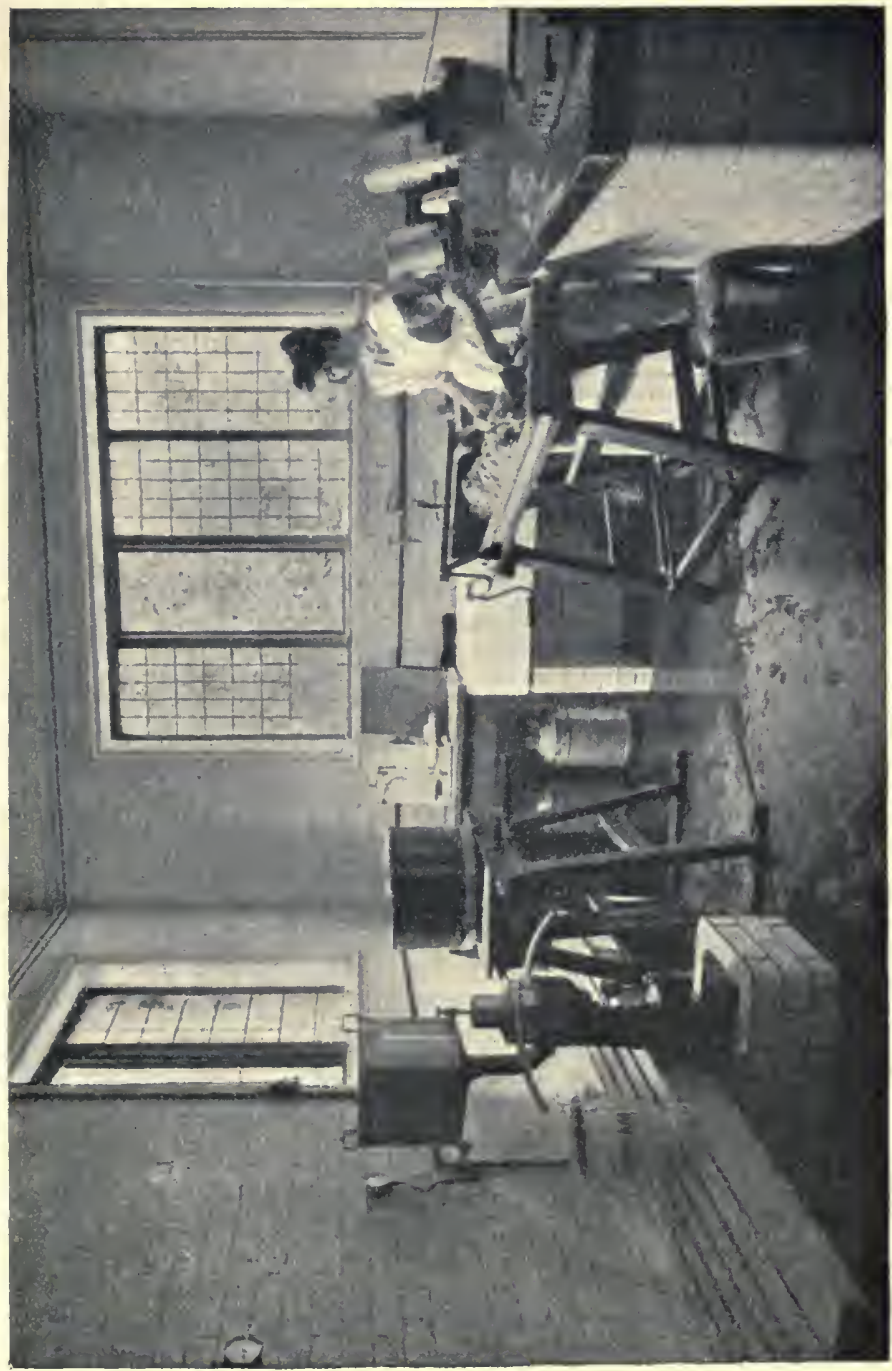

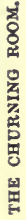


patterns pretty to the eye, it need never be touched by the human hand.

Most makers of butter use a little salt, some more, some less, according to the taste and requirements of the market that they supply.

Great care must be used in salting. If it is not thoroughly mixed with the butter, the latter will look streaky or marbled, and will not fetch the highest price. The best time for adding salt is when the grains are first taken away from the churn. The salt is then added, and mixed by turning the salt and butter over and over. It should then be allowed to stand for a short time until the salt is dissolved, and then the making should begin.

When the salt has been dissolved and the butter grains pressed into solid butter, it must remain in a cool place, covered up with a wet muslin cloth. The wet muslin cloth keeps the butter cool. The cooling is caused by the rapid evaporation, or escape into the air, of the water from the cloth, and the escape of the water into the air from the cloth draws the heat from the butter and so cools it. The cooling makes the butter firm, and adds to the length of time it will keep good and sweet.

Remember that in taking your butter to the market, not only should it be well made, of a nice straw colour, and of a good flavour, but it 
should look clean and attractive to the eye. It will then fetch a few pence per lb. more money, and possibly make the difference between a profit and a loss.

Butter should be firm and not greasy, so that when you cut it with a knife it cuts clean and does not stick to the knife.

Butter ought to contain nothing but fat, but even the best made butter only contains 83 to 88 per cent. of fat, and 10 to 15 per cent. of water.

\section{To make Cheese.}

The principal cheeses made in this country are Cheddar, Cheshire, Gloucester, Leicester, Derbyshire, and Stilton. Each of these cheeses has a different flavour and appearance. The difference of flavour and appearance is obtained by the slightly different methods by which they are made, the different method of ripening them, and the different pastures and food that the cattle feed upon.

It would take far too long to enter into minute details of the various methods of making the different cheeses. But there are certain general principles that guide the making of all hard cheeses.

You have just read that butter particles are independent particles that float about in the body of the milk, and, being lighter than the 
milk, colleet at the surface when the milk is set in shallow vessels.

Now, the eurd that makes cheese does not float about independently in the milk, and will not rise to its surface when the milk is still. The curd is bound up in the milk itself, and the great discovery in making cheese was to find something that would compel the milk to deliver up its curd.

On examining the stomach of a calf that had been feeding on the natural milk of its mother, it was discovered that there was a something in the fourth compartment of its stomach that compelled the milk that it had swallowed to deliver up its eurd. In faet, the eurd necessary to make cheese was found in the fourth eompartment of a ealf's stomach. A substance was then made from the fourth compartment of a ealf's stomach, and called rennet.

There were some old-fashioned methods of forcing the milk to give up its curd, but the modern method of renneting the milk, as it is termed, is by far the best.

The new milk is strained and run into large vessels or tubs. These vessels have around them or underneath them jackets that contain water or steam, so that the milk ean be warmed or cooled as the maker wishes.

The rennet is then added and at once the 
curdling begins. This curdling shows that the rennet is forcing the milk to surrender its curd.

The curd gradually begins to appear in the vat as a solid mass, which, when formed, you can cut with a knife.

The liquid portion of the milk now left is called whey, and this whey is run out of the vat or tub by means of a tap.

The curd mass is heaped up and allowed to drain ; it is cut with a knife so as to allow as much of the whey to escape as possible. Some salt is then added and mixed thoroughly with it. The curd is then cut into small pieces by a mill, and it is placed on a "cheese form." These "cheese forms" are then placed in a press, and great pressure is placed upon them till the cheese is made firm and free from whey.

You can see at once that this rolling, heaping up, cutting, and pressure are to make the curd firm by forcing out of it all the whey.

The made cheeses have then a cloth bandage placed round them and are taken into a curing room, where they remain under careful treatment till they are ready for eating.

It must not be forgotten that the butter fat still remains in the curd and therefore in the cheese; in fact, it is the butter fat that gives cheese a rich flavour. 
The rich flavour of cheese depends on the quality of the cream, as to how the cheese has been made in the vat, and as to how it has been looked after in the curing room.

The whey, all that is left of the milk after the curd and butter have been taken from it, is the sugar and most of the ash, and of course a little butter fat,-not much, - that has been left behind.

Whey therefore must have some good feeding properties, though not such good feeding properties as skim or separated milk, because skim or separated milk has only had the butter fat taken from it, while the curd still remains in the milk.

Whey must be used at once while sweet, because its sugar soon turns to lactic acid, and then it is valueless for feeding.

Whey, when good, helps to keep and fatten pigs, and therefore, on farms where cheeses are made, a plentiful supply of pigs ought to be kept to use up the whey.

There is no work connected with a farm that requires a more lengthened experience than cheese making, and there is no work harder and more anxious.

It is a high order of workmanship to turn out a first-class and well-ripened cheese. 


\section{THE PIG.}

\section{The Wild Pig.}

THE wild forefathers of our present pig of the sty, - the wild pig, - wandered in herds, amidst the woods, thickets, brambles, and jungles that at one time-long, very long ago-grew over a large portion of the world's surface.

These wild pigs had a hard struggle to live, for they had many enemies. The wild bear, the wolf, and the panther knew, long before man knew, how sweet was a dimmer of pork, and so these beasts of prey were always on the look-out to capture and kill a stray pig for dinner.

These wild pigs were tall, long, lean, seraggylooking animals, with large, narrow, sinewy frames, with an arehed back, the bones of which stuck up in a very ugly manner. Their snouts were long and powerful.

In appearanee these wild pigs were very different to the round-bodied, short in the leg, long in the baek, short in the snout pigs that 
we so often admire in well-kept styes and piggeries, and at agricultural shows, when these domestic pigs are reasonably fattened, and not fattened out of all shape and use.

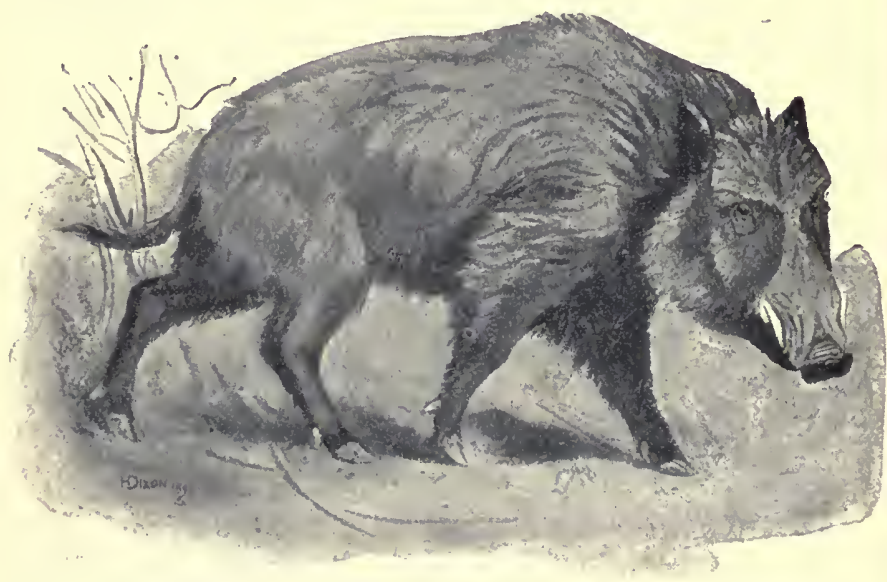

WILD BOAR.

For purposes of mutual defence, these wild pigs lived in herds, so that if one pig of the herd was attacked his head-splitting squeals would soon call his fellow pigs to his defence.

That a pig's squeals are not only cries of fright, but cries for assistance, you can prove for yourself by trying to hold a pig by force in your arms. His overpowering squeals will cause all other pigs within hearing to leave off feeding and sleeping, and will arouse them to excitement, and will cause them to collect in a body, 
and they will look like making an attack upon you as if to rescue their distressed comrade.

Remember that the wild pigs lived mostly in wooded places, where there grew plenty of thick grass, brambles, and undergrowth, so that when a herd of pigs were searching for roots and food they could not keep each other in sight.

The herd therefore had to adopt some sound or signal to keep its members together, and to tell each other and the leader of their herd when they were attacked.

The constant grunt, grunt, grunt of a pig would be a splendid and effective signal to keep a herd of pigs together when they were searching for food amidst the undergrowth, out of sight of one another.

And no more effective sound could a wild pig have used, when attacked, than his piercing squeal.

So you see a pig's grunt and squeal are really forms of rude speech, or signals of speech, to keep the herd together for mutual help, and are also calls from a pig in suffering or danger to the other pigs of the herd for help.

The leader of the herd never failed to answer these squeals of alarm and for assistance; for the wild boar was a brave and perfectly fearless beast, and would attack anything, however small and however large, and by means of his powerful 
head and shoulders could drive his fearful tusks into and rip up the body of his foe.

Very few wild animals, even in numbers, dared ever attack an old boar when he was in such a position that his enemies had to attack him in front, and could not attack him either on his flank or in his rear.

Travellers tell us that the wild boar has been known to kill a tiger in fair fight.

So the common grunts and squeals of the pig, sounds that you must have so often heard, were forms of speech to preserve their lives when pigs in their wild state were hard pressed.

You may be quite sure that all the different sounds, pitches and grades of sound, throughout all the living world around you, mean something, and are understood by other animals of the same kind, so that the different animals and birds used their different sounds or songs, because at one time they were of use to them for self-preservation.

When in the wild state a pig grunted and squealed for such long ages in order to preserve its life and those of its companions, that now he grunts from habit when in his sty, although his grunt can now be of little or no use to him.

\section{A Pig's Shape.}

The shape of a pig, the formation of its feet, the firmness of his well-knit-together flesh, the 
hardness and elasticity of his bristles, all point to the fact that his wild forefathers sought their food amidst the sharp prickles of bramble and dense undergrowth of thick grass and vegetation.

A pig's skin is tough, his coat is bristly, his nose and head shaped like a wedge, so that he can force his way through a dense vegetation. His hide is specially tough about the neck and shoulders, and is covered with bristly hairs, so that the thorns slide along and do not pierce the skin. In fact a wild pig rushing headlong through a thick, thorny, undergrowth of bramble and briars, is not merely uninjured, but probably, by setting up a healthy friction of the skin, it helps to keep him in hard condition and in vigorous health.

A wild pig's head is so shaped, its hide so tough, its hair so elastic, that it can force its way through the densest and most prickly masses of undergrowth with greater ease than any other animal of equal size and weight. And a wild pig, being able to do this, must often have saved its life when chased by its enemies.

A pig can force its way without harm to itself through a mass of undergrowth, which if you were to attempt to follow would tear your clothes and score you flesh with nasty wounds. 


\section{A Pig's Fat Saves its Life.}

You have read that a farmer's great aim is to produce a cow that will give the most abundant flow of milk on the smallest quantity of food and, to produce a bullock that will come to maturity early and put on the greatest weight of flesh on the smallest amount of food.

The great object in feeding pigs to a profit is only to rear and breed from those strains of pigs that will fatten the most readily and quickly on the food that you have about you, and which you can spare to give them.

On a cheese farm there is the whey; on a butter-making farm there is the skim and buttermilk; on a root and grain farm there are the roots and grains; from a cottage, the wash, odds and ends of the garden, thistles, and herbage of the hedgerows.

Some varieties of pigs will do best on one sort of food, other varieties will do best on other sorts of food. Which variety of pig will do best for you can only be learnt, as much else in connection with farming, from your own experience, or from the experience of others in your district who have been successful in breeding and fattening pigs.

The natural inclination of all pigs is to put on a large amount of flesh in a very short time. 
By domesticating the pig, and keeping it in confinement, and only breeding from those sows that look like producing small bones and much flesh, man has considerably improved on the wild pig for fattening and eating.

But man did not create the inclination on the part of a pig to put on flesh in a short space of time. It was necessary for a pig, when in its wild state, in order to preserve its life, to put. on flesh quickly.

This may seem strange reading to you. What, you may say, a pig's fat preserves its life-how can that be? I should have thought the very reverse is the case, - that a pig's fat would endanger its life.

But just try to picture a wild pig's life.

By grubbing for roots with his powerful snout he, probably, during the spring and early summer, got a spare living. By very hard work he just got sufficient food to keep himself warm, keep up his strength, and keep himself alive; just sufficient food, in fact, to take off the edge of his hunger. He, probably, during the spring and early summer never could obtain sufficient food to give him a good square meal that would satisfy his appetite. Therefore he had no chance of putting on fat.

But the late summer and autumn come round, and then the pig's harvest is at hand. The 
beech masts or beech nuts, the acorns,-so fattening to pigs, - and all manner of tree fruits fall in abundance, and then all around is an ample supply of food.

No longer is there any need for the wild pig to work hard all day to search for, and snout up, a scanty quantity of root food, because his food lies on the surface of the ground, requiring little or no effort to find.

The pig therefore can now fill his stomach, satisfy his appetite, lie down and sleep, wake up, and eat of the beech nuts, acorms, and fruits that had fallen during the night or during his sleep.

Therefore, during this time of plenty, the pig not only keeps up his strength and health, but stores up a reserve of fat over and above his immediate requirements.

We cannot think that the pig knew that he was laying in this store of fat to draw upon, against the time of the coming winter, when food would be so scarce and difficult to obtain. $\mathrm{He}$ only ate his hardest and fastest in obedience to what his nature told him to do. The feeling that he must eat all he could of the good rich things around him was laid on him, and he did his very best to be obedient to his feeling.

During this time of plenty, his natural enemies, and especially the bears, left him alone, because 
the bears found that the ripe berries, honey, and nuts were a good ehange of diet for the summer, which they could obtain with much less difficulty than they could eateh and kill a wild pig. There was the danger too of the brave old boar that guarded with desperate pluck the herd over which he ruled with absolute command.

Moreover, honey, nuts, and ripe berries were a more suitable food in the summer for the bears than a meal of pig flesh.

You must have felt in hot weather a much greater inclination to eat fruit, eggs, and vegetables than meat, and you are wise to carry out your inclination, for in hot weather you do not require fogd that creates too much warmth that the hot weather supplies. When the weather gets cold then it is that you feel inclined to eat meat, because meat gives you heat which in cold weather you require.

You must have noticed how all animals in hot weather turn eagerly to cool food. The horse, when in the stable, will eat greedily of the green stuff that ought to be given him; the cow will do best on the young cooling grasses of the fresh pastures; and your pigs will do best on food that does not heat their blood too much.

So you see the wild pig had, during the summer and autumn, every chance of getting fat, but he had to get fat in a few weeks, and so a 
wild pig's descendants, our domesticated pigs, have inherited from their wild ancestors a natural inclination to put on flesh with greater rapidity than any other farm animal.

The wild pig, during the summer and autumn, had every chance of getting fat. The conditions were favourable, with abundance of good food easily obtained on all sides, and little need to be on the look-out against enemies. Plenty of food with peace of mind are the most suitable conditions to enable the wild pig to put on fat in a short space of time.

A pig's inside is so formed that he can eat and digest for his size a large amount of food.

An animal takes in and digests its fogd through the stomach and intestines.

The pig has a small stomach but a long intestine, a longer intestine in proportion to its body than either sheep or cattle. In consequence of the long intestine, pigs are able to digest the food they eat more quickly and more thoroughly than any other animal; and as you have read, it is not the quantity an animal consumes that of necessity does good, but what the animal digests ; in other words, what proportion of the food taken, is turned into flesh, fat, muscle, and bone, that does the good.

Therefore a pig having a small stomach and a - long intestine proves that a pig can eat often, 
and turns what he eats very quickly into increasing the weight and size of its body.

Some careful experiments have been made, and they prove that out of every $100 \mathrm{lbs}$. of food that a bullock digests, 23 lbs. of it go to increase the size of its body. That out of every $100 \mathrm{lbs}$. that a sheep digests 26 lbs. of it go to increase the size of its body.

But that out of every 100 lbs. that a pig digests $46 \mathrm{lbs}$. of it go to increase the size of its body.

These facts show us that a pig can get fat in a shorter space of time than any other farm animal.

Let us return to the wild pig. He has had during the late summer and early autumn a good time of it and got very fat; but now the days begin to shorten, the air gets colder, the leaves have dropped from the trees, all the acorns and beech nuts and fallen fruit that the pig can find have been eaten up. Again he has to work hard with his snout to find his root food.

Then a little later, not only does food become scarce, but the frost hardens the ground, so that even his powerful snout cannot get beneath the soil for the roots that he requires.

Then it is that his terrible trial begins. Not only is all the surface food gone, and the ground hard, so that he can dig with difficulty, or not at all, but his enemies, the bears, have consumed all 
their summer food, and the cold weather makes them long for a dinner of pig flesh. And so the poor pig is constantly on the move, and is always fearful and on his guard against its destroyers.

You can well understand that under such conditions as these, many pigs would die of starvation or be eaten by their enemies, and only those pigs could survive who, in the happy days of abundance during the late summer and autumn, have become very strong and have stored up a plentiful supply of fat. For when the winter days of scant foodwere upon them, the pigs had to live partially on their reserve of fat, and only those pigs could survive that had the largest reserve to fall back upon. Therefore, what we term nature has only preserved those pigs that in the few days of plenty could store up the greatest quantity of fat.

The farmer by his experience has noticed the natural tendency on the part of the pig to fatten quickly on a small amount of food, and has turned that natural tendency to his advantage by domesticating the pig, confining it in a sty, and feeding it for the requirements of man.

A pig will consume and do well on much that would otherwise be wasted. 'The whey from cheese; the buttermilk from the churn; the parings from the potato; the odds and ends left from the table; small roots, and potatoes, that 
the farmer either does not care to eat himself or to give to his stock; the sweeping of the malt house; the grain left after the brewer has brewed his beer; the "bran and sharps" from the outside coats of the grains of corn, the inside of which the miller makes into flour,-all these things the pig will do well upon, and so, by means of the pig the farmer can turn the leavings of his farm into money.

The farmer indeed has to be grateful for that grim effort to lay on flesh in a short space of time, that went on in those far back ages when the pig wandered about in his wild state. And he should also be equally grateful for the fact that all those pigs that could not lay on a sufficiency of flesh in a short space of time were killed by their hungry enemies, or died from starvation during the severe cold of the winter.

It is well known that a pig by itself will not fatten so readily as two pigs kept together, partly, perhaps, because pigs are naturally sociable animals, and have been accustomed to live together in herds, or numbers, gregarious as the expression is. And animals that have been accustomed to live together in herds will fret when they are alone, and will not do so well as when they have a companion.

Another reason is that pigs are greedy, selfish animals. If you watch two pigs feeding out of a 
trough, you will notice that their one object seems to be to get as much of the wash as possible, and they will gobble and swallow with the utmost rapidity, eating far more than they would do if they were alone.

Luckily, owing to their having such a long intestine, they can digest their food quickly, that is, they can turn it quickly into bone, flesh, fat, and muscle.

\section{Why Pigs are Greedy.}

Is there any reason for the excessive greediness of a pig? Why should all animals whose forefathers lived in herds gobble their food down so quickly? Place a plate of food before two dogs, or throw some meat into a kennel of dogs, and then you can see their greediness and selfishness.

But place a plate of food before two cats, and they will pick bits out with the utmost delicacy, and, taking them away, eat in quietness and at their leisure.

What is the reason for these two different methods of eating by the dog and cat? If you wish to live your best, be keen in intellect and become a good worker, try to find out the reason for everything that goes on around you. There is a reason for everything, but owing to our imperfect knowledge we only know the cause of 
or reason for a very few facts. But trying to find out the reason for this and the reason for that makes all the difference between an intelligent man and a stupid one.

Well, why should a pig and a dog bolt their food with the utmost rapidity and greediness, while the cat and the tiger will leisurely and delicately eat their food?

The dog and the pig eat with the utmost vulgarity, while the cat and tiger eat with extreme deliberation.

Now, consider them in their wild state. Dogs and pigs lived in herds, and they had, you may be quite sure, a deal of difficulty in obtaining their food, and when they did find a store it was more than likely that it was not sufficient to satisfy the hunger of each member of the community, and so, to get anything like a meal, each member had to eat its hardest and fastest.

You cannot imagine any condition of things more likely to make an animal greedy or selfish than that.

Now, cats did not live in herds, but in pairs, and so when they killed some animal for food they dragged it away to their eaves, or lairs, and being only two, and perhaps a few little ones, they had more than sufficient food for all, so there was no need for them to bolt their food, and in consequence they ate quietly and at their leisure. 
This is probably the explanation of the different methods of feeding of the dog and pig, and the tiger and cat.

\section{Reason for a Long and Powerful Snout.}

It was a necessity for a wild pig that he should possess not only a very powerful, sensitive snout, but also that he should possess a very keen smell, in order that before he began to dig it should tell him of the whereabouts of the roots upon which to feed.

The modern pig, therefore, inherits from his wild ancestors a very powerful snout. So powerful is it that unless you put a ring through his nose, if there be one brick of the flooring loose, in a single night every brick of the sty will probably be upheaved, and a sight of the utmost confusion await you.

Not only is the pig's snout very powerful, but it is very delicate, so delicate that if there be the least crevice between two loose bricks, up they come, and the work of havoc begins.

A pig's smell for underground roots is so strong that pigs have been trained to hunt for truffles. The truffle is related to the mushroom, and is considered a great delicacy to eat. It is about the size of a plum, or small potato, and grows about one foot beneath the ground, and generally at the roots of certain trees. 
That will show you how strong is a pig's smell for roots when he can tell the hunters where to dig for the truffle, although the truffles grow a foot under the soil.

A pig was once broken in by a gamekeeper to tell the shooters the whereabouts of a covey of partridges, and it was observed that the pig noticed the scent of the partridges when they had been passed over by the best pointer dog.

You see how, to preserve its life in the wild state, an animal adopts certain habits. Man then observes these habits, and seeks out how they can be of use to him, and so he domesticates the animal, presses it into his service. But man goes farther than this; he is not satisfied with the habit of the wild animal, but by selection, or by breeding, and rearing only from those animals that look nearest like the end he has in view, he still further develops the habit of the wild ancestry.

In their endeavours to escape their enemies, to live, and not to die,

a wild horse developed powers of speed,

a wild cow developed powers of milking,

a wild pig developed powers of putting on fat in a short space of time. And these habits aequired by animals, when in their wild state, have been used and increased by man in the service of man, and have added to human happiness and power. 


\section{Is a Pig a Dirty Animal?}

A pig is said to be a greedy, unclean feeder, that will eat almost anything either in the vegetable world or in the animal world. If, however, a pig had been a dainty feeder, he could not have survived the hard time he had to live through when in his wild condition. But it is because he will eat and thrive on almost anything, live when other farm animals will starve, that he is so valuable to the cottager and farmer. The buttermilk after the butter has been made, the whey after the cheese has been extracted, the grain after the beer has been brewed, the dust sweeping of the malt house, the outside leavings of the corn, the odds and ends left on our plate that we cannot or will not eat, the greasy water in which our plates and dishes have been washed, the outside leaves of green stuff grown in our gardens ean all be turned to profit, as food for the pigs. And if a saucepan or eopper is kept going, which always ought to be where pigs are kept, the small and diseased potatoes, every kind of small and diseased roots, nettles, and all the green refuse of the garden or of the hedgeside, ean be put into the copper and boiled into a good dinner for the pigs. If it be near selling time, and you wish to push your pigs on a bit, add to the stew a few handfuls of meal and bran. 
Don't despise the pig and its unclean, greedy habits of eating, because, it is owing to these very habits that he has helped, and is helping to comfort and support many a village home.

It is said that the pig is a dirty animal in its habits. This, however, is not so if the animal is given a chance of being clean. Let the sty face a warm aspect, say south, and let his sleeping place contain some clean litter or straw; let the floor be made of hard blue brick, or better still, of concrete, and let it be so sloped that all the wet drains into a rivulet cut along the end of the sty, which in its turn drains into a cesspool outside his sty. Feed with such food that, while you fatten him, you keep his blood cool, and you will find that he is a cleanly animal.

But give him food that heats his blood, with no cooling salt and green stuff, and let his sty be filled with dirt and slush, with no proper drainage, and the poor beast will naturally lose all self-respect, and roll in the filth to keep the heat of his blood down.

The more you treat animals with consideration and thought, or as you would wish to be treated if you were in their place, the greater will be your success with them and the more money you will make out of them.

The sweeter will be the bacon, and therefore, 
the better price will it fetch, if the pig be kept under wholesome conditions and fed with wisdom.

But not only does our pig consume all the waste, but after death he leaves no waste behind him.

After death all his parts are useful. His head is made into brawn, his brains into fritters, his toes and feet are boiled and eaten as Petty 'Toes, and excellent they are. The blood and some of his fat are made into rich black puddings; his skin is made into saddles, hence the expression when a man is on horseback that he is in the "pigskin" His bristles, especially those of the wild boar, are made into brushes. His internal fat is made into lard; and other internal parts are eaten as "fry" and "lights." The body when fresh is cut up into joints, and when smoked is salted and eaten as sides of bacon, gammon, and hams.

\section{Different Breeds of Pigs.}

It may be said that pigs can be divided into three distinct classes, - the large white Yorkshire, the red Tamworth, and the improved black Berkshire. The improved black Berkshire is the favourite pig, and a good-looking, well-balanced animal he is.

Its colour is black, hair short, fine in the skin, a small, short, intelligent-looking head, with 


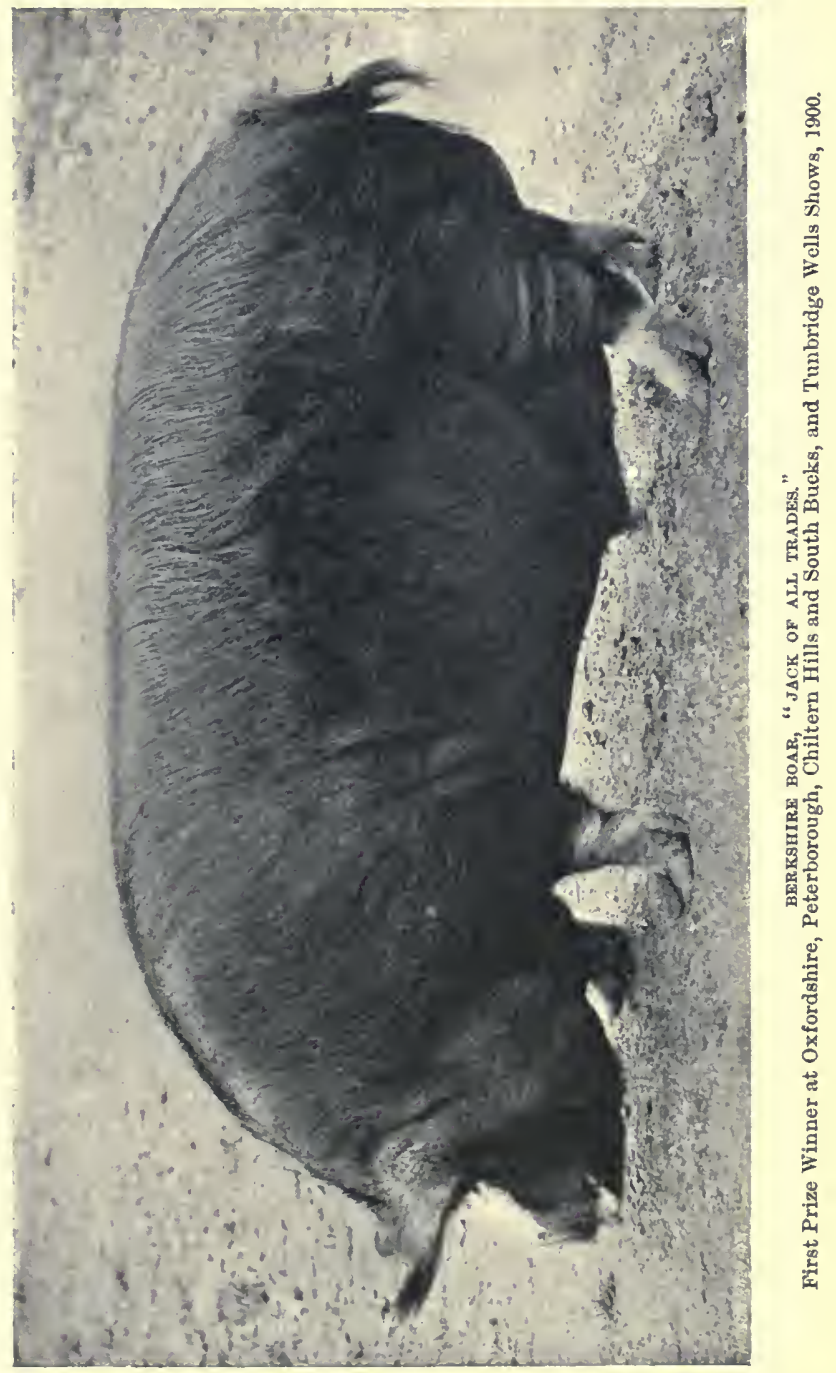


small prick ears, short in the leg, broad and deep in the belly, long and straight in the back, and a tail well put on that curls stiffly round and round. If you see a pig's tail. well and stiffly curled, you may be quite sure that the animal is in good health. If the tail is uncurled and hangs limply down, it is a sign that there is something wrong,--that the animal is out of health.

The pure-bred Berkshire has his face a little white near the tip, and his nose, feet, and tip of tail white.

The improved Berkshires will do well on the most scanty fare. As the saying is, "they will fatten where other pigs would starve." This of course is very greatly in their favour.

Moreover, the Berkshires, being medium-sized pigs, having small bone, being long, in the back, deep in the belly, and standing close to the ground, make the kind of meat that the present market requires, namely, small joints, and produce "sides," that when cut up for bacon do not show excessive fat, but with the lean and fat reasonably mixed.

A pig of average fatness, that weighs from 10 to 12 score, will fetch more money per score than a much fatter pig weighing, say, 15 to 20 score.

There is no farm animal that pays a small 


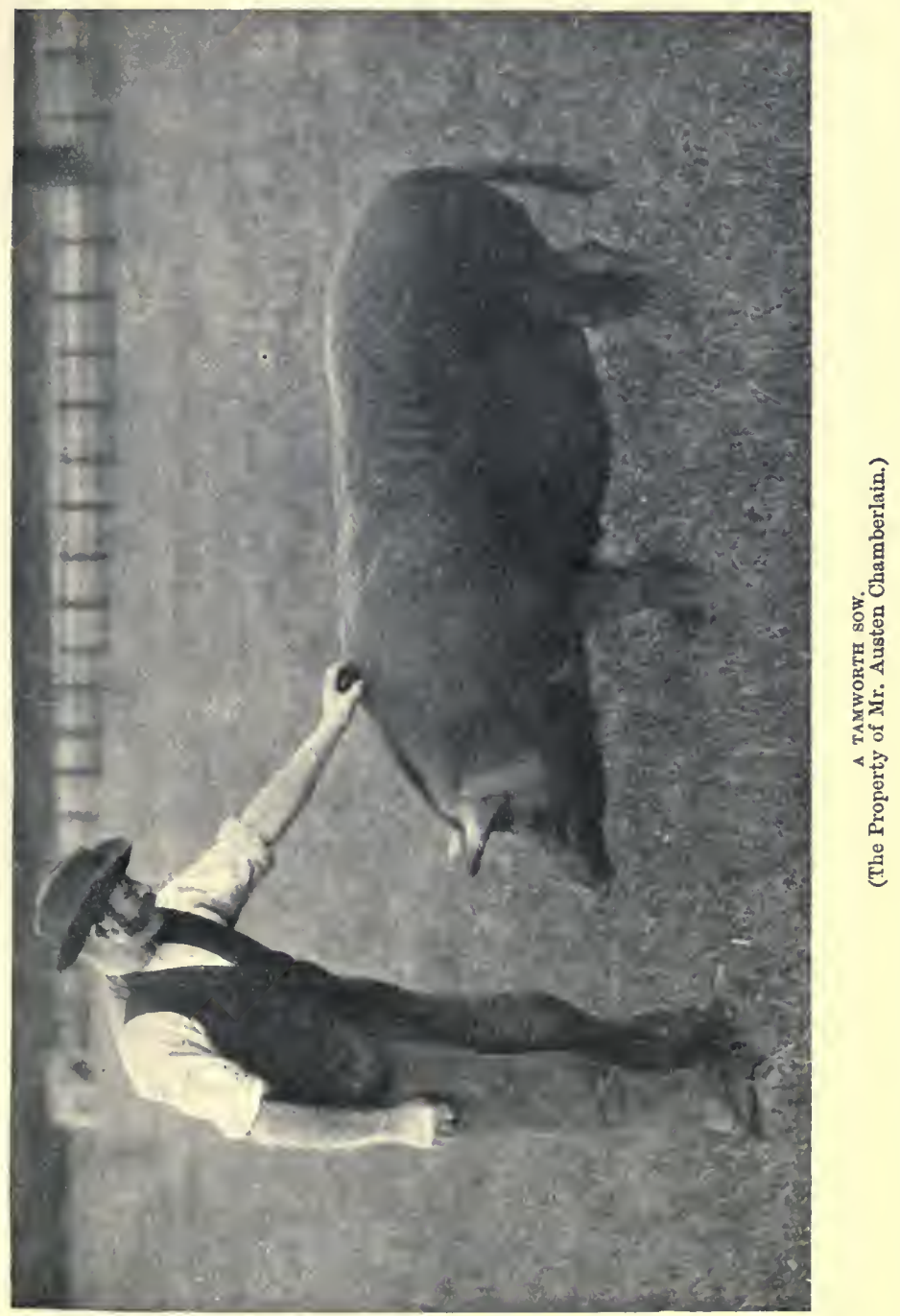


farmer or cottager better, when the accommodation is suitable, than a well-bred breeding sow. With luck and good management she will rear two litters a year, ten or twelve at each litter, and the little pigs soon after they are weaned will sell for about $£ 1$.

A sow has paid the rent of many a small holding.

Young pigs should be born about the latter end of March or early in April, and towards the end of August, because there is less chance of their being, killed by cold weather. Moreover, in warm weather they require less feeding.

Not only will a pig eat up and turn into money all the waste of a farm, but his manure is most valuable. Especially is it valuable to a cottager who has difficulty in obtaining manure for his garden and for his bit of land.

Even if the pig were not profitable otherwise, the villager should keep one for the sake of its manure.

Now, this is very important. Only keep and breed from well-bred stock. To obtain a good strain of animal may cost a little more money at the outset, but it far more than repays itself afterwards. A well-bred animal does not cost more money to keep than an under-bred onc. In fact, the well-bred animal costs LEss to kecp, 
because it fattens to a profit more readily. The well-bred animal fetches more money in the market, because its meat is so much more tender and has so much more flavour.

In these days when competition in agricultural produce is so keen, and the profits in consequence are so elose, every point must be taken advantage of. This is no time for slovenly, ignorant farming. That man only ean expect to make a living out of farming, whether he farms a few acres or many acres, who knows his work, is methodical in his habits, and is alive to take advantage of every well-tested experiment; the man, who, at the smallest cost, grows the heaviest yielding erops, and keeps and rears the most profitable and suitable strain of live stock.

In conclusion, it can be said with truth, that, under good management and proper attention, few animals can be kept at a greater profit than pigs.

But to feed pigs to a profit, the food must be obtained at a small cost-that is to say, all the remains that would otherwise be thrown away, and many other things of the field and hedgerow, that cost nothing beyond the time and trouble of collection. Much that comes under the name of refuse or waste, ean, by the pig, be turned into money. 


\section{THE SHEEP.}

\section{Wild Sheep.}

THE ancestors of our domesticated sheep developed their covering and muscles of leg and power of neck and head, in order that they might live with the greatest advantage amidst their wild, cold mountainous surroundings.

The wild sheep of to-day live on high mountainous places, constantly covered with snow. On the slopes and terraces of these cold heights they take refuge when danger is near, and live on the scanty herbage that they find there.

The wild sheep live in parties of two or three or in flocks of considerable size.

Generally speaking, they inhabit open mountainous districts rather than the very craggy region inhabited by the wild goat.

Travellers tell us that it is a grand sight to see a flock of these wild sheep, some as large as donkeys, with their enormous wrinkled horns, moving with wonderful grace and agility amongst the glaciers on the mountains, or resting amidst the castle-like crags of the mountain summits, sometimes at a height of more than 12,000 feet.

The experience of the long past has made the wild sheep of to-day very wise. When they rest they select for warmth a position that catches 
the sun and a spot that gives their sentinel a wide look-out, so that they can easily see the approach of their special enemies-the wolves.

Not only do these wild sheep select a place when resting that gives them a wide vision, but they often select a spot so that the scent of an enemy will be borne to them on the wind, whichever way it approaches.

In the lambing season-the spring-in order to obtain greater warmth for their lambs and a more plentiful supply of young nourishing grass, they descend towards the plains.

The fights that at certain times take place between the horned rams are very terrible. When a fight is on, these silent, desolate heights echo and re-echo with the thunder-like claps that the crashing together of these massive heads and powerful necks and horns make.

No doubt the hardest head and strongest neck only could survive these fights to the death or to a finish, and so there has been handed down to their descendants-our domesticated sheep-a hard head and powerful neck.

The cousins of the sheep---the antelope and deer-had a good chance of escaping their flesheating enemies by their extraordinary swiftness of foot, but the sheep, not having this power so highly developed, had to adopt some other means of saving themselves from extinction, and so 
they took to the snow-covered mountain sides as a refuge.

Their instincts, shape and colour, and covering of back had to become adapted to life on the mountain sides, and therefore only those sheep could survive and leave descendants who could do this.

If the wild sheep was to live and not die, it had to climb up steep slopes and slide down almost perpendicular sides of hill and mountain ; it had to climb over great gaps and crevices in the ground, and leap from ledge to ledge on high precipices.

Think how such a life as that must have caused the muscles of the leg to have rounded and become fleshy, which with care and breeding on the part of man have developed into full, juicy, tender legs of mutton.

Amidst these wild desolate regions the horned ram keeps careful guard over his flock; he is always on the look-out against the wolves and jackals and two-footed man.

The flock also have their sentinels, and if any danger is approaching, the alarm signal is given, and the scattered flock gathers together in a body to obey the instinctive sheep law of "Follow my leader" - a law that the experience of ages has taught the sheep is best for their escape and safety. 
These wild sheep, remember, have no great open plains over which to gallop away, where it does not so much matter if they are in a compact body, directly following their leader, or no. But they have to escape mostly along narrow ledges cut in mountain sides, and so their wisest plan is to collect together in a dense long body and to faithfully follow the lead of their leader.

In that rushing, headlong flight, with a pack of hungry enemies at their heels, the flock were compelled to follow every movement of their leader, whether that movement was in direction, speed, or leap.

While scurrying up and down these steep places, broken here and there with yawning chasms and deep ravines, the individual sheep had no time to look and judge for itself.

In the most perfect initation of their leader lay their safety, and woe betide that flock whose leader wavered and faltered, whose judgment was at fault, and whose nerve and speed were not at their best.

\section{Wild Habits Still Linger.}

If we notice carefully our domesticated sheep we shall observe that they retain many interesting habits that were useful to their wild ancestors, but which of course can serve no useful purpose now. 
These habits were indulged in for such long ages by sheep before they were domesticated by man, they became so deeply rooted in the family of sheep, became so instinctive, as it is termed, that many of them still linger.

The wild impulse of the long past arises, and the domesticated sheep partially obeys that impulse.

Let us now consider some of these curious habits that you all must have noticed.

It is by observing the natural ways and habits of the young of animals that we are able to decide, with great certainty, what were the ways and habits of their wild ancestors.

Lambs when at play select the steepest part of a field, and, if there is a rock or log lying about, they will skip on to it and butt at one another from it.

The shepherds of the South Down sheep tell us that if any of their flock, during the night, break from their fold, they are mostly to be found on the highest ground of the neighbourhood.

Lambs have long legs, and when a few days old are capable of keeping up with the flock. If this had not been so, the beasts of prey would soon have made an end to the race of sheep.

If a flock of sheep, scattered over a field grazing, become alarmed, or if the sheep dog be sent amongst them, they will immediately collect in a body and follow the lead of a leader. 
You must all have noticed that, if one sheep of a flock gets through a partially open gate, all the rest will blindly follow the lead. And you will find it a very difficult job to stem the rush. The writer has seen a boy who tried to stem such a rush completely taken off his legs by a large flock of sheep.

If a sheep jumps down from a height, say down a sunk fence, and the others are alarmed, the whole flock will collect and jump down from almost the same spot, even at the risk of breaking their slender legs.

You must often have noticed, that when a flock of sheep are travelling in a compact body one of the flock will for no apparent reason jump high in the air, and when the others come to the same spot, they will jump likewise.

Here is a lingering wild habit. While galloping in headlong flight, the leader of a flock of wild sheep, on coming to an opening in the ground or any impediment, would jump to clear it; the rest of the flock being close together would not have the time nor space to pause, look, and judge each for themselves, but each member would jump at the exact spot in exact imitation of its leader.

What a wise sheep law this was. For, with a body of sheep compacted together in a long narrow line, and travelling at great speed, to 
pause and to look would have caused those behind to push those in front into the ravine or break in the ground, and would certainly have much lessened their speed, and thus have given the beasts of prey their chance.

If a dog enters a field where there are ewes and lambs, he will often be attacked by the ewes if he ventures too near. This is probably a relic of the old wild instinct, when the horned flock on the mountain side defended themselves against jackals and wolves.

An angry ewe will often stamp her feet when a dog comes in sight. This is probably the relic of a danger signal that the wild look-out sheep gave to the flock over which it was guarding.

It also may be a signal that the animal intends to fight; like a man, before he begins to fight, turning his shirt sleeves up, or waving his clenched fists about in the air.

Animals closely related to the sheep will use their sharp hoofs with deadly effect.

For instance, deer will destroy snakes by jumping on their bodies, and with a quick outward movement of their feet tear them to ribbons.

Travellers tell us that antelopes use this method of attack, and hunters have been killed in this way by the big antelopes that live in the Himalaya mountains. 
For purposes of defence, sheep in the wild state developed great strength of neck and the hardest of hard heads.

All of you have seen two quite young lambs butt each other's head with very considerable force.

And if two powerful rams get together, they will charge blindly at one another, at several yards' distance. Down will go their heads, the butting of their two skulls sounding like a clap of thunder. The recoil will drive them right backwards, but up they will get and go for each other again till one is the victor, or the neck of one is broken.

\section{The Sheep of the Farm.}

Man thinks for himself, he looks around, observes, then ponders on what he has seen, and then further he considers how can this or that in wild nature be made useful to him. How can he use it so that his life may be made more comfortable and happy.

And so some very early man must have observed the covering of a wild sheep's back, and it must have occurred to him that a sheepskin, with its covering, would be a very warm protection for men against the cold of winter. And so he tried the experiment, and the experiment was successful, and the successful experiment caused men to capture and domesticate the sheep. 
Man, however, is not satisfied merely to make use of the wild life that surrounds him, but he finds that by careful seleetion and breeding he can, for his own wants, considerably improve upon it. He can in course of time almost mould it to his will.

The farmer and agriculturist have developed various breeds of sheep.

According to their land, climate, and the demands of their nearest market, the farmers of one district have bred one variety of sheep, in another district they have bred another variety.

Your own observation, combined with the experience of your neighbours, will tell you which. is the most profitable breed of sheep to keep in your neighbourhood.

Generally speaking, the point at which to aim is to breed a hardy, healthy sheep that will come to maturity early, give the richest and most delicately flavoured meat, and grow the warmest, most durable, and softest wool.

If you succeed in this, of course, you have reaehed a high pinnacle in the art of sheep rearing.

\section{The Different Breeds.}

Mountain Breeds are the Welsh, Cheviot, and Highland. These sheep are small, active animals, making deliciously flavoured small joints of meat. 


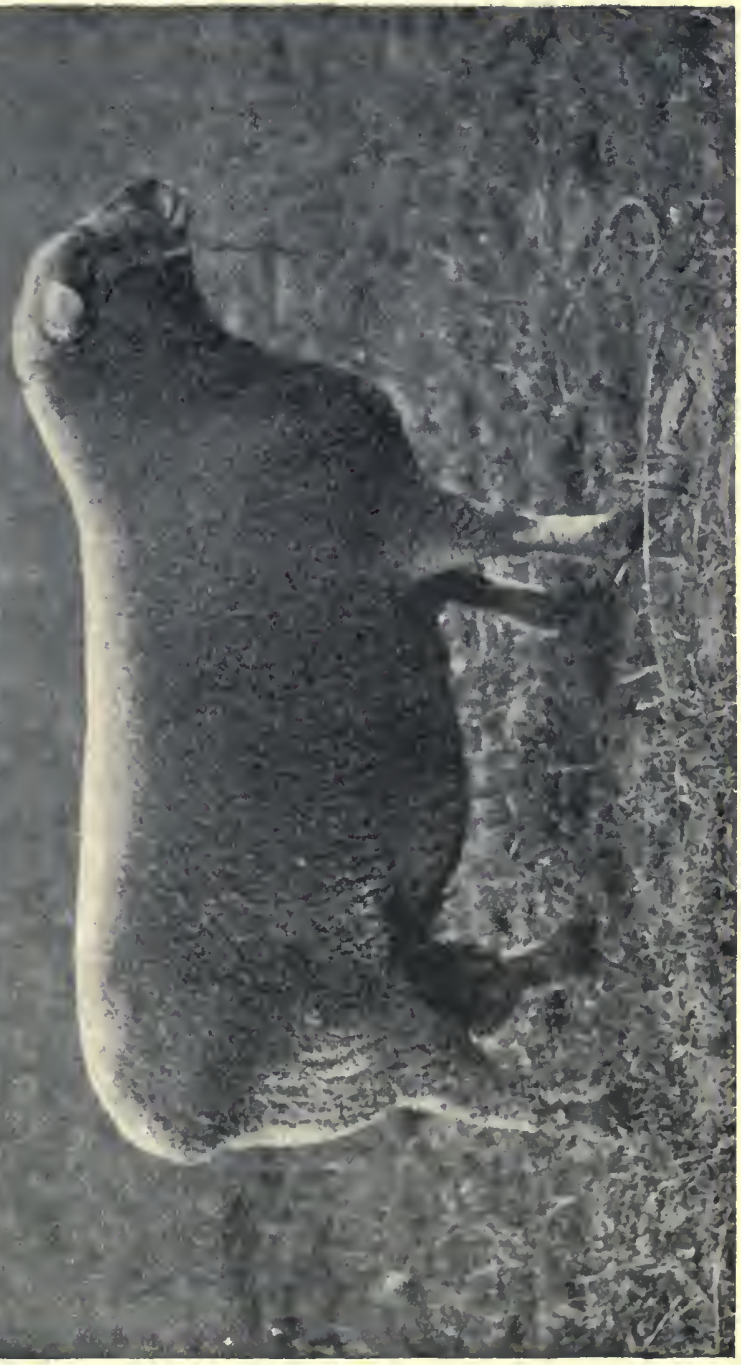

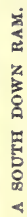


Many of these breeds are horned.

The principal Upland or Hill Breeds are the Dorset, the South Down, Suffolk, Hampshire, Shropshire, and Oxfordshire. These sheep are short in the wool and medium-sized animals.

Lowland Sheep are the Cotswold, Lincoln, Leicester, and Romney Marsh. These sheep are larger in the body and grow longer and coarser wool than the upland sheep.

At the present time the Lincoln and the Shropshire sheep appear to be mostly in favour with our colonists and the foreigner.

These breeds are exported in considerable numbers in order to improve the flocks over the seas.

A little time ago, a Lincoln ram was sold for 1000 guineas, and was bought to improve the flocks in the Argentine Republic. This is the highest recorded price ever given for any single sheep.

The Shropshire sheep now is justly a great favourite. It is a very hardy sheep, arrives at maturity early, and grows a short but very saleable wool. It tends to produce too much fat for the demands of the present-day markets, these demands being lean meat and small joints.

But it should be remembered that if you wish to produce the best quality of meat, there must be a certain amount of fat. 
In the opinion of the writer, the surest test of good meat is its fat and how it tastes and looks when on the table as a cold joint.

Many farmers are now crossing the Oxford and Shropshire breeds. The Oxford gives size and the Shropshire gives flesh.

Sheep reared in England giving the most marketable wool are the Lincoln, the Shropshire, South Down, Oxford, Hampshire, and Leicester.

\section{About Wool.}

The sheep breeders of Saxony examine the wool of their sheep under a microseope, and only breed from those sheep whose wool is found to be the softest and most abundant. By this eareful and scientific method the sheep-breeders of Saxony have been rewarded by producing a breed of sheep yielding an abundant supply of the softest and most beautiful wool.

Sheep do not shed their coats at certain periods of the year like many other animals. The South Down flockmasters, however, tell us that at certain times of the year the wool or fleece lifts, or " is up," which means that a certain division between the wool and the skin takes place, and then it is that the shears run easily, and the labour of shearing is much lessened.

The lifting of the Heece is really caused by the 
fibres of the newest growth erecting themseives, and therefore lifting the matted fleece slightly.

If sheep are not fed well and wisely the best wool will run back in quality, and therefore will not sell for the best price.

Our bodies are kept warm because our clothes prevent the warmth that is made inside our bodies escaping into the air.

Wool is fine and open, and therefore holds a great deal of air amidst its fibres, It is this air practically that prevents the heat of the body escaping, and so keeps the animal warm. Wool, therefore, is said to be a poor conductor of heat.

You all know that the wool of a sheep's back is made by the manufacturer into the woollen clothes that we wear.

There is something in the nature of the wool itself that helps the manufacturers to do this. Let us see what it is.

If you examine a fibre of wool under a magnifying glass you will see that it is made up of sections or parts, and you will also find on these fibres little joints or scales. So that when several of these fibres are pressed together these little joints or scales eatch one another and so hold the fibres together-the wool, as we say, "felts" well. Here you have the principle of making woollen clothes.

Another interesting fact. From the skin of a 


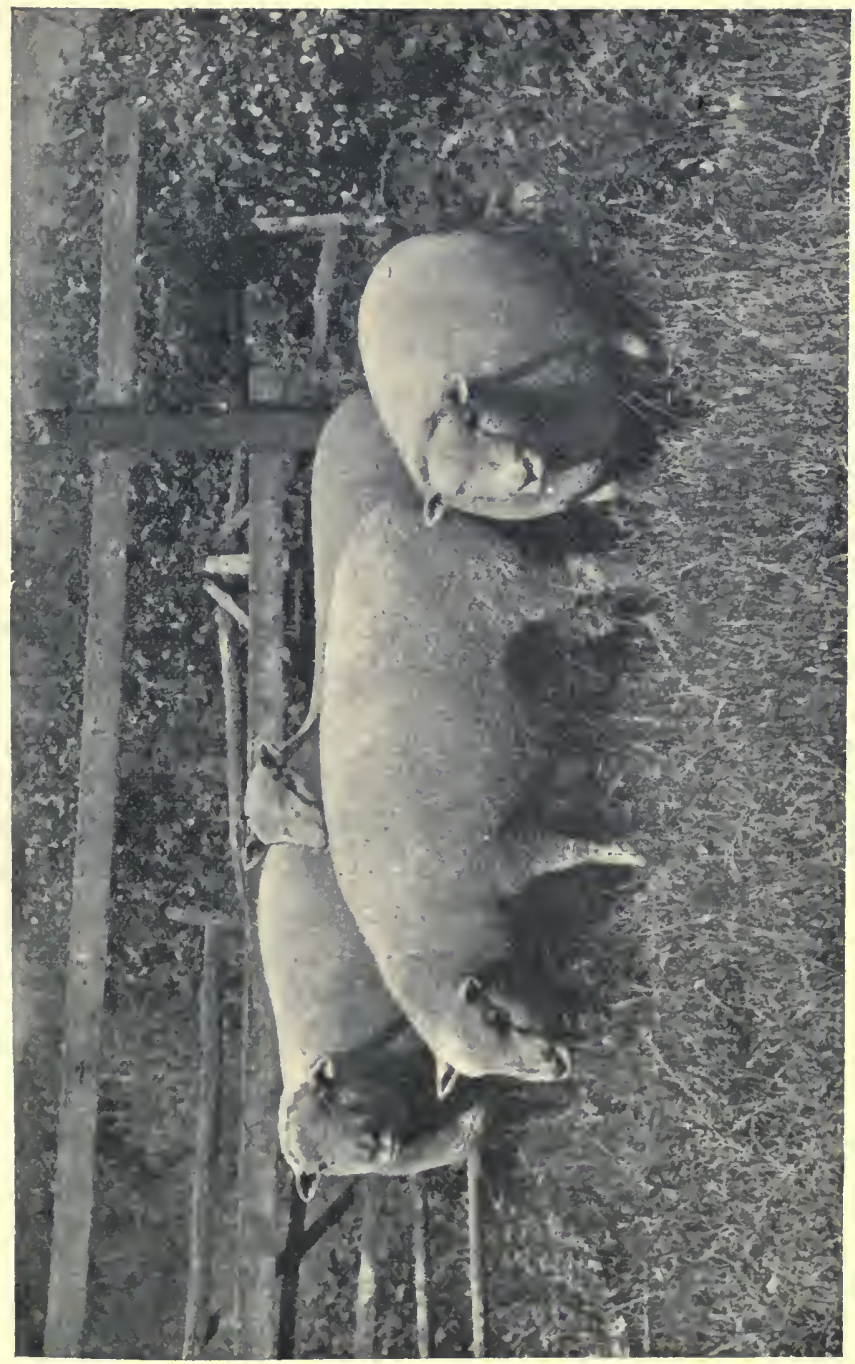

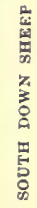


sheep there comes a soapy substance called yolk which covers the under wool and helps the animal to shed the rain. This keeps the body dry and prevents the wool on a sheep's back from felting. When the fleece is washed this yolk is washed out and the fleece becomes much lighter.

Notwithstanding this wise provision of nature, sheep cannot stand constant wet, either overhead or under foot, but they thrive best in cold, dry weather, on dry, well-drained soil.

In taking your wool to market see that it is cleaned and prepared so that it is attractive both to the eye and to the touch.

Wool buyers have told the writer that English wool often fetches a price under its real value because farmers neglect to take this trouble.

Many thousands of pounds each year are lost to the agriculturists, fruit growers, and gardeners of this country because of the slovenly and inartistic manner their produce is sent to market.

\section{Care and Feeding.}

As wild sheep originally had their home amidst cold and dry regions, it is necessary that the pasture of the domesticated sheep should be dry and well drained. The pasture also should be constantly changed, and care should be specially taken that the animals be not crowded too thickly on the ground. 
If sheep are fed with a little corn or cake when on the pastures or leys, there is no animal that does the land more good.

They graze close to the ground, eat much herbage that cattle and horses refuse, and their manure is a most valuable food for the strong nourishing grasses and clover.

It is an old and very true saying, "Manure your land through the mouths of your live stock." Manage your mixed stock of horses, cattle, and sheep with wisdom, and you will keep your grass and clover land in good heart.

Manage your stock on common-sense principles, feed them liberally, but don't overdo it; give them constant change of pasture; from time to time chain harrow, and, if possible, roll your grass land, and it will have a thick, wellknit-together bottom of good nourishing feed, looking as green and rich as a well-kept lawn.

In the spring sheep are fed off the young grasses. As the summer goes along they are fed on vetches and clover, and in the autumn on cabbage; in the winter on roots, mixed with corn, cake, and chopped straw.

On light arable land, where there is grown an abundant crop of light roots, sheep are often folded ; that is, a portion of the land is luurdled off, the outer hurdles being advanced each day. By this system the sheep are compelled to eat off 
the crop, with little or no waste, and at the same time they tread down and manure the land with great uniformity.

On the heavier and richer land better use can be made of the large and heavy roots, that such land grows, than to fold sheep on them. These roots are stored for the winter, chopped up, and given to the live stock, mixed with corn and cake and chopped hay and oat straw.

When roots are given in this manner they are cut up by a cutter. The trouble and expense of cutting them up is well repaid, because the animals eat up the slices without waste and with less fatigue to themselves.

It is a bad plan to feed sheep only on turnips, because turnips are a very watery food. Every 10 lbs. of turnips contain 9 lbs. of water.

'Therefore, for sheep to get enough solid food from turnips, they are compelled to eat a larger bulk of food than they require.

Remember that the great principle in fattening all animals is to give such food that, while keeping them healthy, will be turned into the best quality of bone and meat with as little exertion to the digestive organs of the animal itself as possible.

Therefore, if the animal takes in with its food too much water, as sheep do when they are trying to satisfy their appetites on turnips alone, an enormous amount of energy on the part of 
the animal is used in bringing the water up to the temperature of the body, which energy ought to be largely devoted to the growth and fattening of the animal itself.

This is an illustration of wasteful feeding.

So, when sheep are folded on turnips, if they are to be prepared for the market to the best advantage - that is, at the least eost, each day they ought to have some hay or dry food given them.

Lambs are born in the early part of the year and late spring, their birth depending on the climate.

The wether lambs, as I daresay you know, are the male lambs, and it is to the advantage of the farmer to fatten these male lambs as quiekly and as early in the year as possible.

Prepare your things so that you send them to market when there is every chance of a scarcity, and then you are fairly sure of obtaining a paying price for what you want to sell.

Prices, as you know, are regulated by supply and demand. If there are many buyers and fewer sellers, the market stiffens, as it is termed; that is, prices will go up. If there are many sellers and fewer buyers, the market will ease, and the prices will go down.

Rock salt should always be at hand for all animals to liek, and also a plentiful supply of pure water. 


\section{COUNTRY DOGS.}

\section{The Wild Dog.}

THE ancestors of our domesticated dog, the wild dog, lived in communities or packs. And in order that they might live in these packs, to the best advantage to themselves, they were compelled to obey certain unwritten dog laws.

To be successful in hunting their prey, in defending themselves against their enemies, in protecting and rearing their off-spring, a set of rules was a necessity.

If you think, you will at once understand that all animals that lived in herds, flocks, or packs, were obliged to obey certain laws if the race was to live and not die out.

Every dog for himself, with no regard for his companion dog, would soon have put an end to the race of dogs.

A number of dogs working in harmony and rendering each other mutual aid would have a much better chance of obtaining a supply than a single dog hunting for itself.

Moreover, a single dog hunting alone would have had a poor chance of running down and killing an animal much bigger than itself.

But the largest animal, possessing the most formidable horns, or the hardest kick, or the 
sharpest and largest teeth, would have small hope of escape with a pack of hungry dogs, yapping and barking all around, just waiting for an opening to rush in.

Then think how much better ehance a pack of dogs have of finding and keeping their scent than a single dog. One dog loses the scent, another dog picks it up, and with tongue and wagging tail tells the other dogs of its happy find.

Then the searching, spreading dogs gather together at the joyful well-understood signal, and with noses to the ground and tails in the air away they go fast on the trail of the unhappy animal they are hunting.

'The writer has many times seen two terriers who knew perfectly well that it was wrong to go a-hunting, gambolling round each other, in the most innocent manner playing about his lawn, and trying to make believe that they were not thinking of doing any wrong. All the time, the two rascals had hunting in their hearts, and in their play were getting further and further away from their master, till at last away they went, no shouting would then stop them, to return some hours afterwards dirty, with their tails between their legs, and a most woe-begone look in their faces, having probably caught and torn to pieces a rabbit or two. 
The old instinct of their far-away hunting ancestors arose in their hearts, and it was stronger than the love, or the stick, of their master.

And the old hunting instinct also had taught both the terriers that they had a better chance of catching their rabbit if they hunted together than alone, and so they arranged it between them.

Anyone who has ever watched a pack of foxhounds at work, and is gifted with a slight imagination, can picture the working of a pack of wild dogs, the wild ancestors of these foxhounds.

At a word from the huntsman, with tails in the air, they spread themselves over the covert in search of the strong scent of the fox. At first no whimper is heard, not a note, all is quite silent, save for the cracking of twigs and occasional call of the huntsman's voice. Then one keen dog pauses, suiffs quickly and earnestly, his tail quivering with emotion, a signal that the scent is near, but that he has not quite got on it yet. At last he picks it up, and with note and tail gives the well-understood signal to the pack. And the spread pack gathers gladly from all parts of the covert to get on the scent that the fortunate dog has found.

You can see what a much better chance a wild 


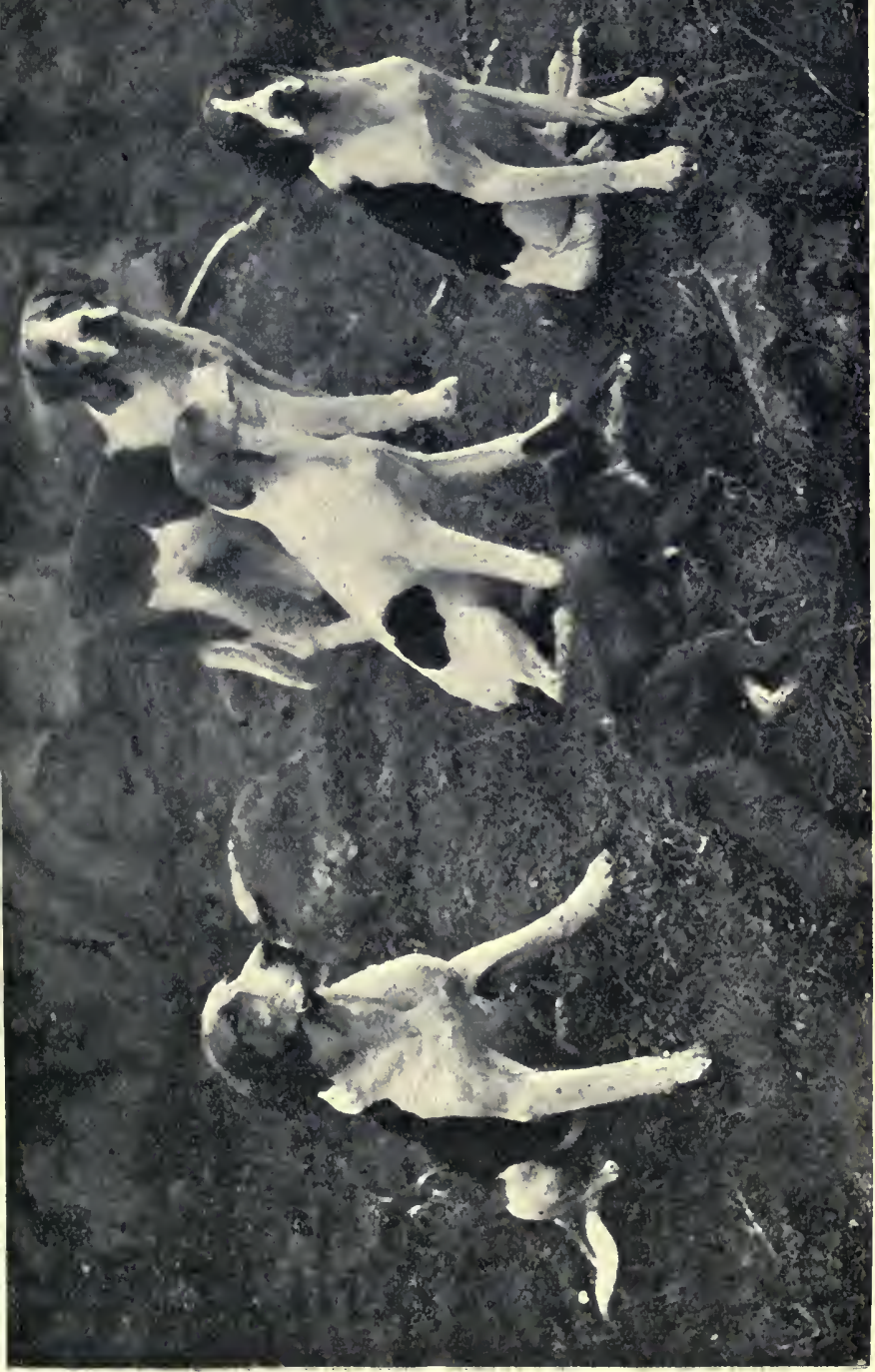


pack of dogs had of obtaining their prey, if they gave each other mutual help in searching for the scent, and, when the scent was found, giving the joyful find note.

\section{Expressions of a Dog's Tail.}

How endless are the expressions betrayed in a dog's tail! It tells of joy and pain, of fiercest anger or wildest affection; whether the dog feels shame or self-respect; whether he is bubbling over with strength and spirits or is dead done with weariness or fatigue; whether the scent is near or is found; whether the prey is just within reach of mouth and claw.

Then, watch two dogs-strangers to each other-walk round each other, and take stock of one another. At other times watch how, at a distance, they will lie down and point at each other, and then rigidly arise and very slowly and carefully advance, and, having come up to each other, very proud and erect, they will, depending on whether they are naturally friendly or antagonistic to one another, have a rough and tumble, or pass on with the utmost unconcern. You can read it all in a dog's tail.

Every movement and habit that we observe in our domesticated animals had its first beginnings in the ways and habits of their wild ancestors.

And these ways and habits, remember, in 


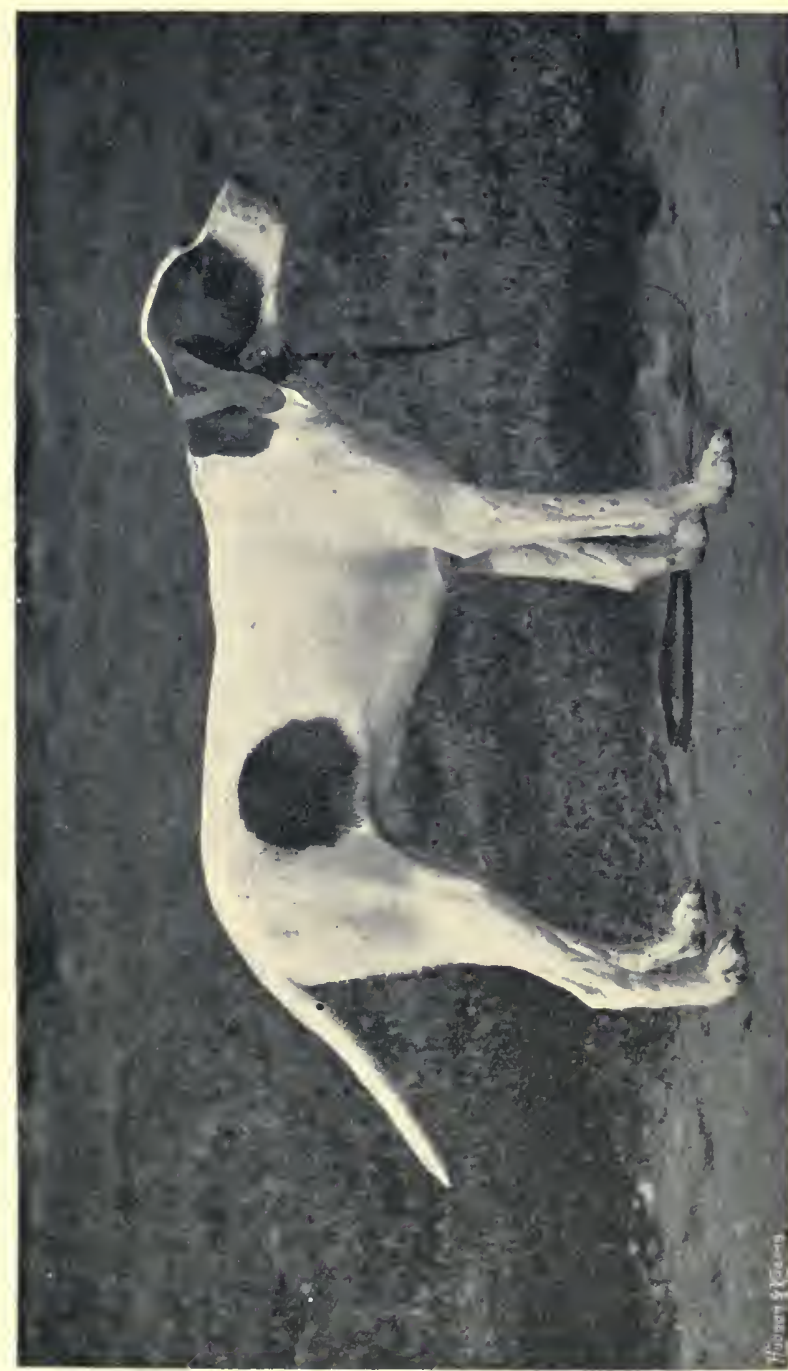

造 
their turn had their beginnings, ${ }^{-3}$ because they were of some use to the wild race that adopted them.

Man observed the habits of the animals when in their wild state, or he captured and tamed the young of the wild animals, and then afterwards found out the ways that were natural to them. Whichever way man learnt of the wild traits, having found them out, in order to make them the most serviceable to him, he either partially suppressed them or modified them, or turned them in some other direction; or he very strongly developed them.

\section{Why Dogs are Sociable.}

Dogs, as you have just read, lived in packs. Experience had taught the race of wild dogs that union meant strength, meant beating off their enemies, meant a better chance of obtaining a bit of sheep, deer, or even some other larger animal for supper. But when the prey was pulled down and killed, mutual help was at an end. Every dog for himself was then the rule, and so each dog erammed and bolted the utmost amount of food he could swallow; without any regard for the other dogs of the pack.

The wild dogs, living in packs, had in a measure to give and take, had to learn and obey a rude sort of obedience to the unwritten dog 
laws, had to render a partial obedience to the leader of the pack.

Any dog of the pack that through an unruly disposition would not obey, or any dog that through a deficiency of strength and cunning could not obey, was soon cast out of dog society as being unfit to live.

So you can see at once that this made a dog inclined to be a sociable animal, and, therefore, he had not much trouble in adapting himself to the superior social ways of man.

Speaking generally, all animals that live in packs and flocks are more easily domesticated than those animals or birds that live a solitary existence or live in pairs.

The cat and tiger tribe, who in their wild state live in pairs, are more difficult to domesticate than the dog tribe, who live in packs.

The barks and growls of a dog that protect our houses, is the old wild instinct that guarded the lair of the pack.

The yells, barks, and shrieks of a dog in distress that will bring around all other dogs within hearing distance, and the bark of a watch dog, that sets all the other dogs within hearing barking in their turn, is the old instinct of dogs in packs barking for help or in defiance.

The spaniel rushing through brambles and undergrowth is the old instinct of hunting. 
The rounding of the flock by the sheep dog, and running them in any direction that his master may direct, is a wild kind of hunting, with the killing at the end almost stamped out.

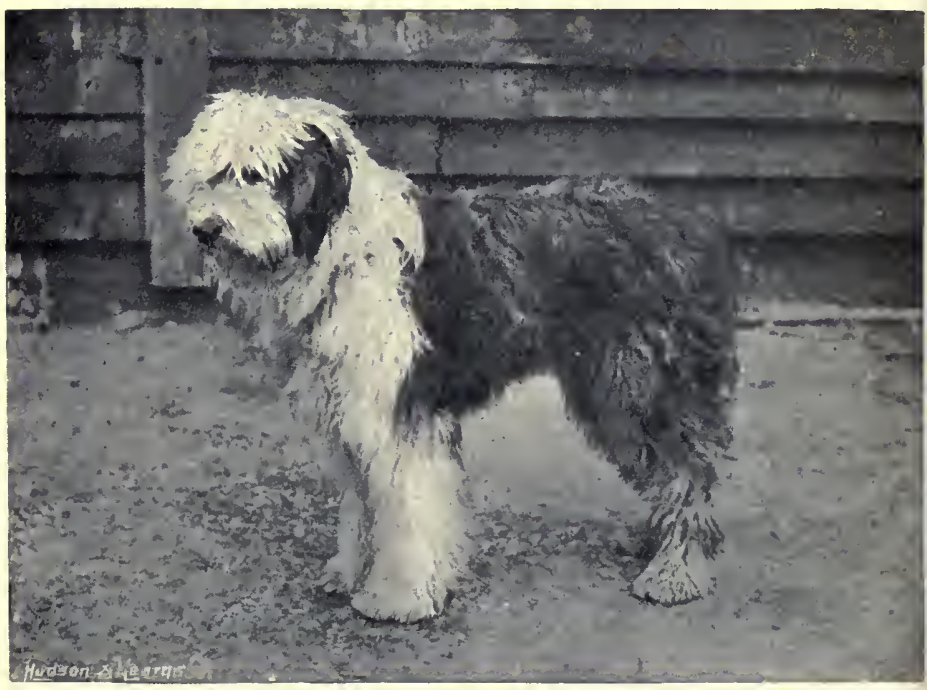

OLD ENGLISH SHEEP DOG, "ORSON."

May not the pause of the pointer when he stops and points, directly the smell of the partridge on the air reaches him, be the old instinct highly developed of the pause that a wild $\operatorname{dog}$ makes in order to give him the final strength necessary to jump with rapidity and accuracy on to his prey? Was not the obedience 
of the $\operatorname{dog}$ to his master first learnt, when the wild dog was compelled to obey the leader of the pack?

The keen sense of smell that enables a terrier to gallop at break-neck speed on the track of a rabbit, that enables the pointer to "nose" on the air the scent of the hidden partridge, that enables a bloodhound to track man by the scent arising from his footsteps; were not all these wonderful powers of smell first impressed on the race of wild dogs when their very existence depended on their keen and accurate sense of smell?

Man has taken all these natural instincts and trained them to be of service to him, until the dog has become his close and useful companion.

There are so many ways and habits in the animals that are about you, that will interest you, if you will only observe them with kindness and sympathy in your heart. And the more you know of them the more they will interest you, and the greater will be your success in rearing and keeping them.

\section{Different Breeds of Dogs.}

It would take far too much space in a short Reader to describe all the different breeds of dogs.

We can only briefly refer to those in most general use in the country. 
Foxhound. This dog has been most carefully bred; it is said to be the most perfect specimen of the $\operatorname{dog}$ races. It is built so as to combine speed with great powers of endurance or staying power. A pack of foxhounds (26 couples) once sold for the large and exceptional sum of 5219 guineas.

The average weight of the single dog is from 70 to $80 \mathrm{lbs}$.

Pointer. This dog, it is said, was first brought into this country from Spain and France about the year 1720. It was much thicker and clumsier than the present dog.

In America and Canada, the pointer is trained to fetch game or retrieve, while in this country the dog is trained to point, or stand game. Average weight about 50 lbs.

Retriever is a good-looking, all-round, sagacious dog, and makes an excellent companion; one variety is curly in its coat, another variety is flat or wavy in the coat.

This dog should have a kindly and sensible look in his face, for the work that he is put to requires more cleverness than that of most other' sporting dogs.

It is a pretty sight to see a beautifully coated black retriever searching for the missing wounded game, and, when he finds it, pick it up with so tender a mouth that he hardly disturbs a 


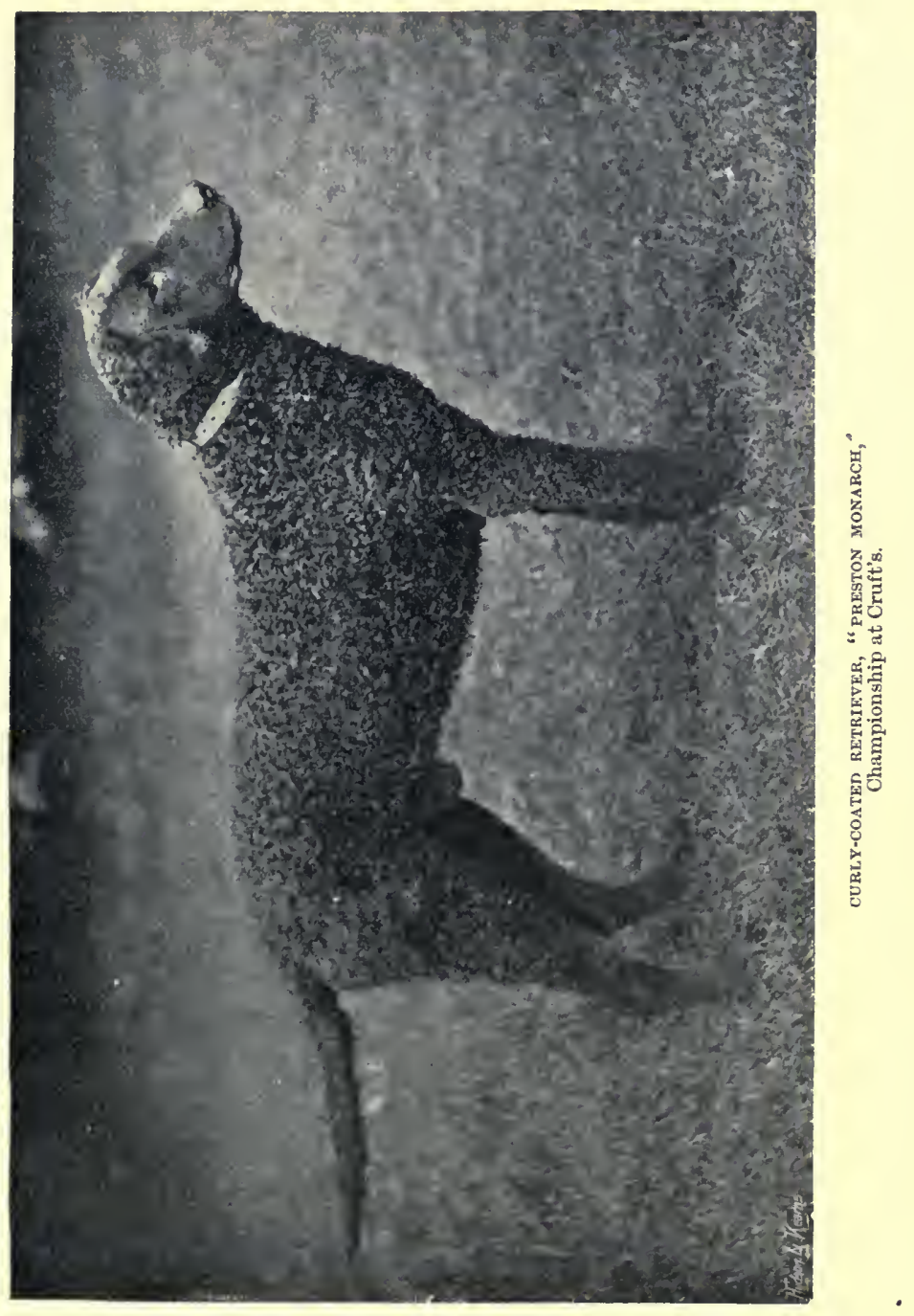


feather, and lay it with respect at the feet of his master.

Average weight from 40 to $60 \mathrm{lbs}$.

The Spaniel is a delightful dog. The variety known as the clumber spaniel is the favourite. This dog is long and massive in the body, with a long coat, short in the leg, ears that are long and flapping, white in colour, with liver or lemon markings on the head and ears.

The clumber is a good water dog and a most useful dog for sporting purposes. He works about 20 yards in front of the gun at a steady trot or slow hard gallop. He is trained to stand or drop with a movement of the hand, or at the moment that the gun goes off, or when the game is flushed and flies. This dog will also retrieve game.

The spaniel is a slow dog, but does not tire easily.

The Terrier. The fox terrier is probably the most popular dog in this country. He is quick, alert, and affectionate. He is ready to fight or jump on your lap; ready to follow on the trail of a rabbit, or to lie sound asleep on your mat, yapping in his dreams, as he goes over in his mind the latest chase or fight; ready to try conclusions with the biggest tom cat of your neighbourhood, or, with a knack learnt from experience, kill rats so rapidly one after the other that at last he drops down from pure exhaustion. 


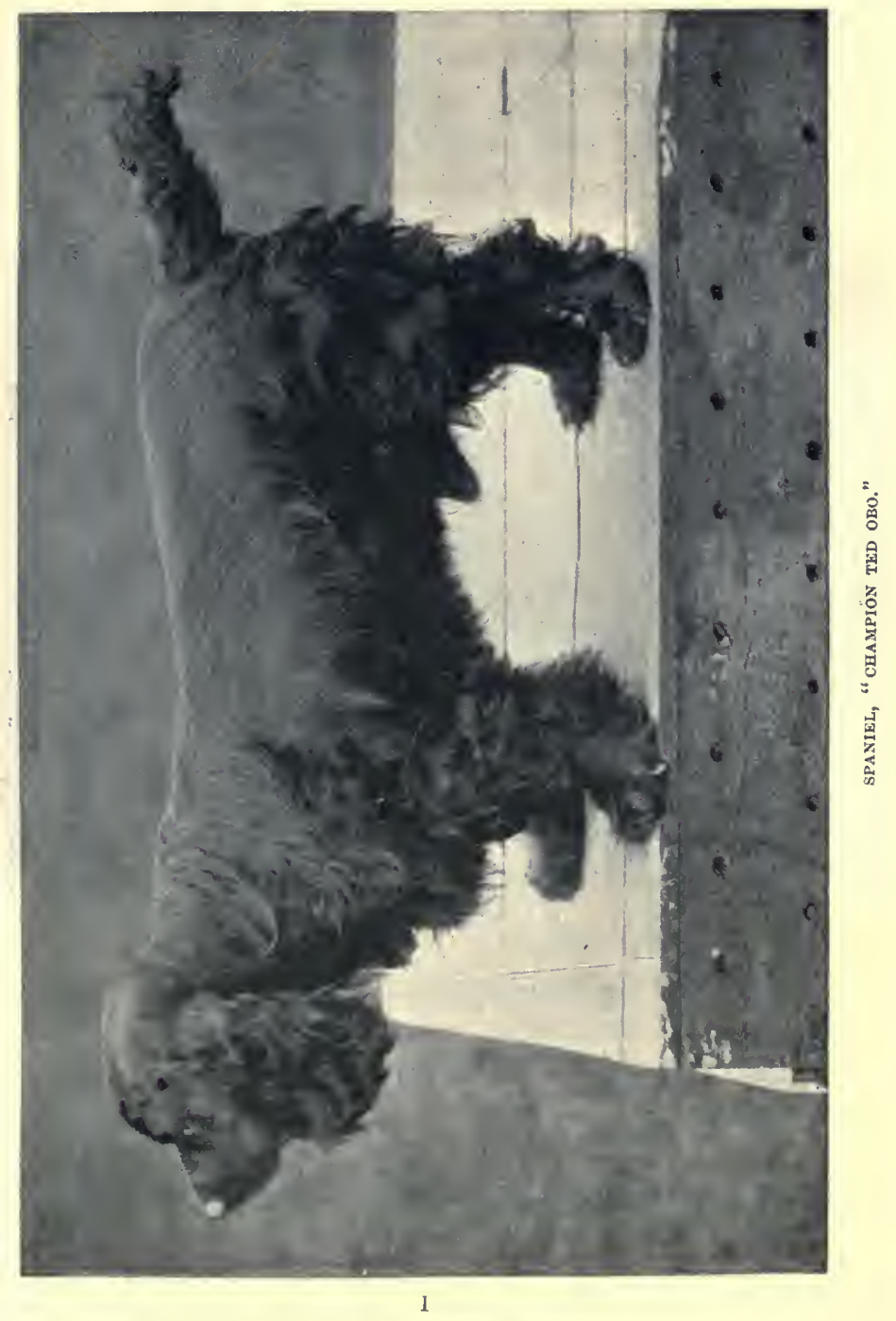


The fox terrier was originally bred to rum with a pack of foxhounds, so that when the fox goes to earth the fox terrier disappears in search of him, and when he finds him, lie is taught not to close, but to stand barking till fox and dog are dug out.

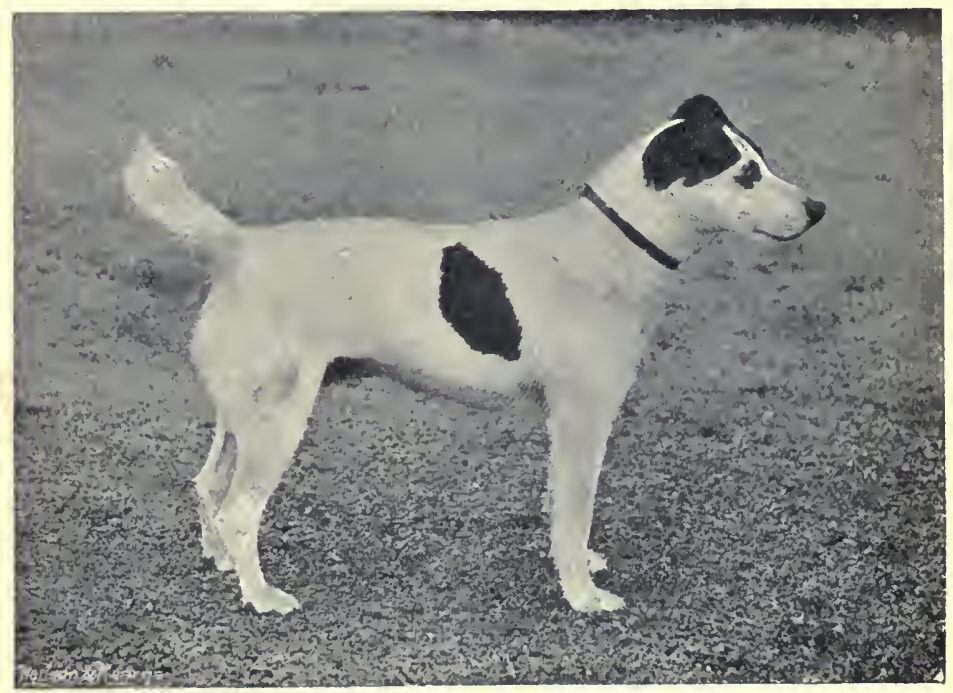

FOX TERRIER, "VENIO."

As much as $\mathfrak{E 0 0}$ has been given for a fox terrier.

The wire-haired terrier is also a great favourite, and is a plucky game little dog. The coat, as the name tells you, is longish, and of a harsh feeling to the touch. The coat of the fox terrier is much shorter and smocther. 
The Irish terrier is a plucky, handy dog, good tempered to his master, but somewhat inclined to look upon all other dogs as his natural enemies, and to fight whenever he gets the chance. His coat is wire-haired, somewhat long, and is reddish brown in colour.

\section{Sheep Dogs.}

We now come to the sheep dogs, the most intelligent and the most useful of all our dogs.

Have you ever thought that in many parts of the world, and in parts of this country, it would be impossible to rear sheep if there were no sheep dogs?

In the Highlands and in many other mountainous regions, and in countries where there are huge flocks of sheep scattered over thousands of acres of poor soil, as in some parts of Australia, where five acres will only support one sheep, the sheep dog is an absolute necessity.

Without a dog it would require more money spent in labour to manage a flock of sheep, gather them from the hills, force them into their folds, and drive them to market, than the whole flock would be worth.

As you know in this country the sheep dog drives the sheep before him, but in the East the sheep follow the shepherd, and the dogs simply 
defend their flocks against beasts of prey and robbers.

In South America the sheep follow the dog, and this is how it has been accomplished:

When the dog is quite a puppy it is taken from its mother and placed with a live sheep, who rears it amidst the other sheep as she would her own lamb. The dog, when grown up, shows no desire to leave the flock. The sheep get used to the dog, and the dog gets used to the sheep; but, curiously enough, the dog gradually assumes the position of leader of the flock.

Travellers tell us that when you approach a flock of these sheep the dog immediately advances barking, and the flock closes in his rear for protection, just as they close in the rear of a leading and protecting ram.

The dog has been trained to come daily to the shepherd's house for food, though it may be several miles off; on receiving the food, the dog returns to guard over the flock.

Also, these intelligent dogs have been taught to bring the flock home, without aid from their masters.

The varieties of sheep dog now in most general use are the well-known Scotch collie and the lessknown old English sheep dog, with a short stump of a tail, known as the bob-tail sheep dog. 
The Scotch collie is a wolfish-looking dog, with semi-erect ears and pointed nose. If you notice one running after a trap, when he gets a bit tired and inclined to lag behind, all his attitudes, paces, looks, the position of head and

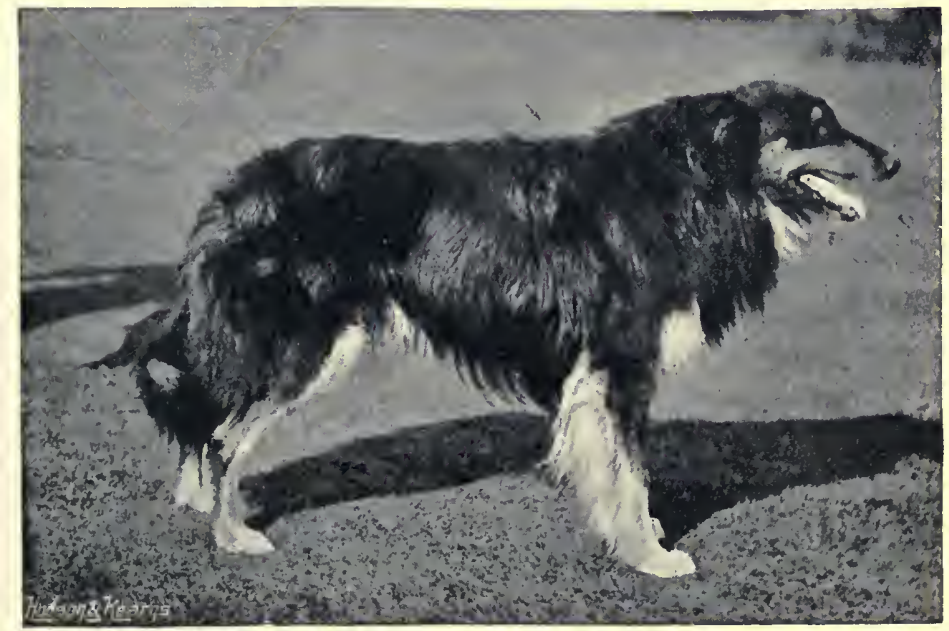

SCOTCH COLIIE,

ears, are very like the pictures we see of wolves when they are hunting in packs.

In consequence of the sheep dogs being all day, and perhaps all night, with their masters, who know their own minds and see that what they say is carried out, they have developed remarkable intelligence. Every word, look, and gesture of their master is understood and obeyed. 
At one word or wave of the hand these elever dogs will round and drive to the fold sheep scattered over miles of hill and dale, and not one will be missing.

And, what is even more wonderful, they will turn out any strange sheep that may get with their flock.

\section{How to Train Sheep Dogs.}

In training dogs, remember this, never change your mind. Be patient, but very firm; see that you are obeyed, and under no circumstances lose your temper.

If you wish a dog to lie quietly, say, under the table or in a corner so as not to be a bother, or to get in the way while you are having your meals, always.make him go there ; don't one day make him lie there, and another day call him away.

A certain word and gesture ought to mean that he is to perform a eertain act. Always then use the same word and gesture when you wish him to do that particular ast.

Dogs are often ruined, and become great nuisances to themselves and everybody about them, beeause their masters or mistresses have not strength of will.

Here is another important point. If you wish to keep your dog in good health don't over-feed hinı; it is eruel to give a dog too much food 
when he gets little or no exercise. It is better for the dog to let lim be a bit spare than too fat.

Remember that naturally a dog had to hunt most of the day for his dinner, and, when he captured it, there was probably barely sufficient to go round.

Of course it depends on the size of the dog, and the amount of exercise it takes, as to the quantity of food it should be given, but as a rule, once a day is sufficient, and then only just what the dog will eat up with relish.

As you know, we give off our superfluous intermal heat by perspiration through the pores of our skin that are situated all over our body, but a dog can only perspire through its tongue. Therefore it is of the utmost importance that dogs should be able to get at a plentiful supply of fresh water-especially is this necessary for dogs with long coats like sheep dogs.

To neglect giving any dog, especially a longhaired one, water, is brutal. The suffering that the poor beast on a hot day must go through from lack of water must be terrible.

\section{What Selection has Done.}

When you come to consider that the tiny, smooth Italian greyhound and the thick coated huge St. Bernard probably descended from very much the same stock, it will give 
you some idea of what power man has in his hands by selection.

A man wishes to breed a dog say for special speed. He has a litter of puppies; he then selects and rears only those puppies or that puppy of the litter which looks like being a bit faster than the others.

These seleeted puppies have in their turn puppies, and again he selects and rears only those puppies of the litter that look like being a bit faster than the others. In this manner he goes on selecting, rearing, breeding, generation after generation, till at last he breeds the greyhound that wins the Waterloo Cup.

Another man thinks he would like to breed a very strong and massive dog. He also has a litter of puppies, and he also selects and rears only those puppies that look like being, 'not a bit faster, but a bit the stronger, more massive than the others.

These selected strong puppies have in their turn puppies, and again he seleets and rears only those that look like being a bit stronger than the others, and so generation after generation he goes on selecting and rearing in the direction of power and strength till at last he breeds a powerful mastiff that can pull a man to the ground.

From very much the same original stock see what a variety of dogs man has bred. 
And it all has been done by man first making up his mind what he wants. And, when his mind is made up, it is followed by accurate and long-continued and patient observation, wise selection, and great painstaking.

The long coat of many of our domesticated dogs has been produced by method in breeding, namely, selecting and rearing only dogs that had a tendency towards a long coat.

The original dog was and is wolf-like in appearance, with a close, woollen coat that resisted all sorts of weather. The long coats are not sufficiently close to the body to afford much protection against bad weather; they are, therefore, more ornamental than useful.

The natural weather-resisting coat was, and still is, close, thick, and more like flanmel in appcarance and touch than anything else.

We are told that if a smooth-coated dog is kept for any length of time in a cold, damp kennel, and left to rough it, the coat has a tendency to revert back to the coat of the wild dog.

Selection is so important in everything in connection with the farm and garden, so important to success, that it cannot be too often or too strongly insisted upon.

Take poultry. The two points that the successful rearer has to aim at is to rear in the early spring a nice-looking, meaty chicken that can be 
marketed on the smallest amount of inexpensive food, and to rear hens that will lay the greatest number of eggs when eggs are scarce and dear, namely, in the winter and early spring. Now if a poultry rearer only set the eggs of those of the hens that showed a disposition towards carrying out these two points, and went on doing this year after year, there is no knowing to what perfection a cottager might not bring his few head of poultry.

Remember that if you are to select wisely, you must learn to observe; therefore, see the importance of training your powers of observation, especially when you are young, and the iniportance of keeping your eyes open. And the more you train yourself to observe the more you will see.

The man or woman who has trained his or her observation, who is always on the lookout, sees numberless things of beauty, interest, and use, that the untrained observer never sees.

The unobserving man is the blind man; the observing man is the seeing man, and, as a rule, the thinking and interesting man into the bargain. 


\section{POULIRY.}

\section{Wild Fowl.}

In the jungles or woods of India there is found to-day a wild fowl somewhat like, in colouring and appearance, to the domesticated game fowl.

When Europe was in an uncultivated condition, when there stretched far and wide tracts of forest and wood, with dense undergrowth of bracken and bramble, uncleared and unclaimed by man, a wild fowl similar in appearance to that found to-day in the jungles of India, lived and wandered without restraint.

From this wild fowl it is said that most of our domesticated fowls have descended.

Had it not been for man's needs, the original wild fowl would still have wandered here and there as it desired, and in appearance and habits would have remained unaltered, and then no Plymouth Rock, Wyandotte, or Buff Orpington would have tamely wandered in our stackyards and poultry runs.

Man at one time lived and wandered as a hunter. When he exhausted the game in one district he just simply moved on to another district, and as the world was so thinly populated there was nothing to hinder him.

To live in this fashion required extensive 
tracts of country, in which dwelt few or no human beings. But slowly man began to increase in numbers and populate the earth, and so hunting and wandering became impossible.

Families growing into tribes, and tribes into populous communities, compelled wandering man to settle in one district.

Having settled down in one district, if men were to live and not to starve, they had to cultivate the ground and become agriculturalists. Settled men had to force the ground to produce larger quantities of improved grain, improved kind of roots, and to coax trees and bushes to bear larger and better flavoured fruits.

The needs of settled man compelled him to tame and improve the strength and swiftness of the wild horse, to carry his loads both behind him and on his back, to feed and breed a cow to give him a more abundant supply of milk, and poultry to give him more eggs, and a more delicate and more certain supply of flesh food.

While man was in a wandering condition, what need was there to tame and confine the wild fowl? There were plenty of them all around, so he went outside his dwelling, and with sling and stone, or bow and arrow, or with spear or by trap killed or captured what he required.

It was a cheap and easy way of securing food. But when man settled down in one spot 
he was obliged to become an agriculturalist or starve. To save his life, man dug and tamed. He would not have done it had he not been compelled.

Man's necessities compelled him to catch and confine the wild fowl, to improve their power of laying eggs, and also their power of putting on in a short time a quantity of white flesh.

If man wanted a good table fowl he "set" the eggs laid by those of his hens that looked like making rapid growth, fine white quality of flesh, and a large amount of meat on the breast.

If man wanted a large quantity of eggs he simply "set" the eggs laid by those of his hens which had laid him the greatest number of eggs in a given amount of time with the least inclination to sit. And so he went on, selecting and selecting in this manner, till, in the course of time, we possess a race of hens that have lost a mother's instinct, and do not offer to sit.

This race of hens has been bred mostly around the Mediterranean Sea,-Ancona Andalusians, Leghorns (Italian), Spanish, Houdans (French).

But most keepers of poultry require a strain that will lay a fair amount of eggs, and chickens that will grow quickly, on the smallest amount of food, into fine tender birds for eating; a fowl that will sit close to her eggs and make a good and faithful mother; and so for general 
purposes there have been bred, the Cochins from China,-handsome birds, but poor layers, and only moderate for table purposes, Plymouth Rock from America, like the cuckoo in plumage, - a good all-round bird and economical to keep, Wyandottes, also from America,--very good table birds, good layers and sitters, and quiet, contented birds in confinement, Buff Orpington, and many others.

\section{Where and How to Rear Fowls.}

The most suitable soil for rearing cocks and hens and turkeys is a dry, sandy soil. They seldom do well in damp, marshy places.

A damp and moist soil is the best situation for ducks and geese, because it is amidst damp and wet that ducks and geese pick up a quantity of food that they require. But a moist, clay soil that retains moisture is the worst situation for rearing poultry.

If you wish to be successful in rearing poultry, they must be regularly and carefully fed, and above all things, they must not be overcrowded.

If the fowl house or ground becomes foul or dirty, a heavy death rate is sure to ensue.

A few hens, carefully selected, wisely fed, and cleanly kept, will do, and pay better, than a large number of ill-assorted hens crowded together. 


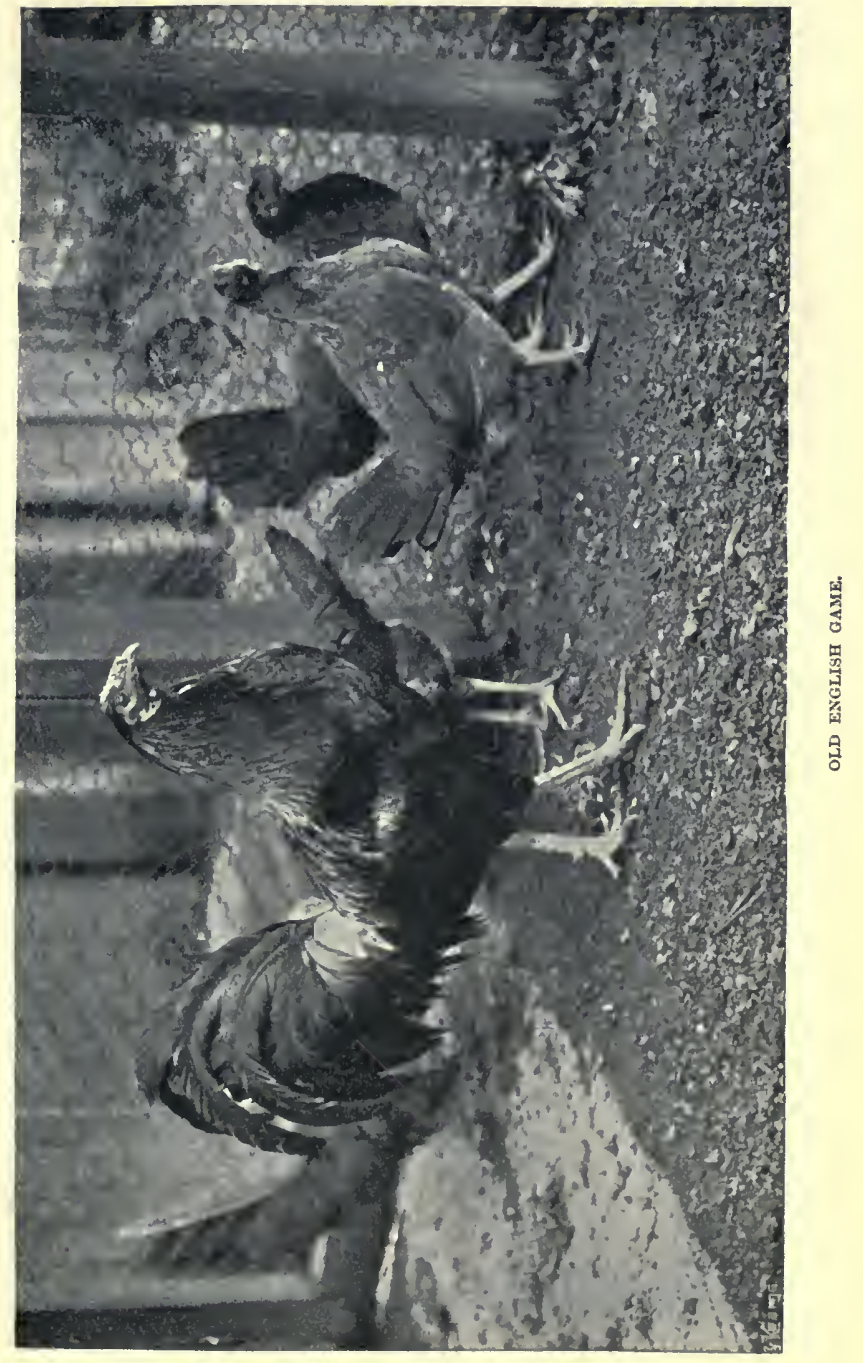


The best method of housing poultry is by means of moveable houses that can be obtained from the makers for a very small sum. These houses are so built that they can be moved from place to place. They contain a shelter underneath as a protector against rain and wind, which also acts as a dust bath. The nest boxes can be reached from the outside, so that the eggs can be taken without going inside the house. The perches are broad, and placed within two feet of the floor. The floor is in two parts, so that from time to time it can be taken up and well scrubbed. The house is freely ventilated from the top, and well lighted by windows. Moving these houses about from place to place prevents any one stretch of land being fouled,a matter so essential to the fowl's health and the well-being of the land.

Fowls that are not too thick on the ground will, by their droppings, manure the 'land, and will keep down insects, and spread about the droppings of farm animals, and scratch up moss, and aerate the roots of the good grasses.

Moveable houses can be moved about the grass fields, placed on the ploughed land and stubble, and in the summer the fowls housed in them will, if not placed too thick on the ground, nearly find their own living.

The cottager, if he have a garden and under- 


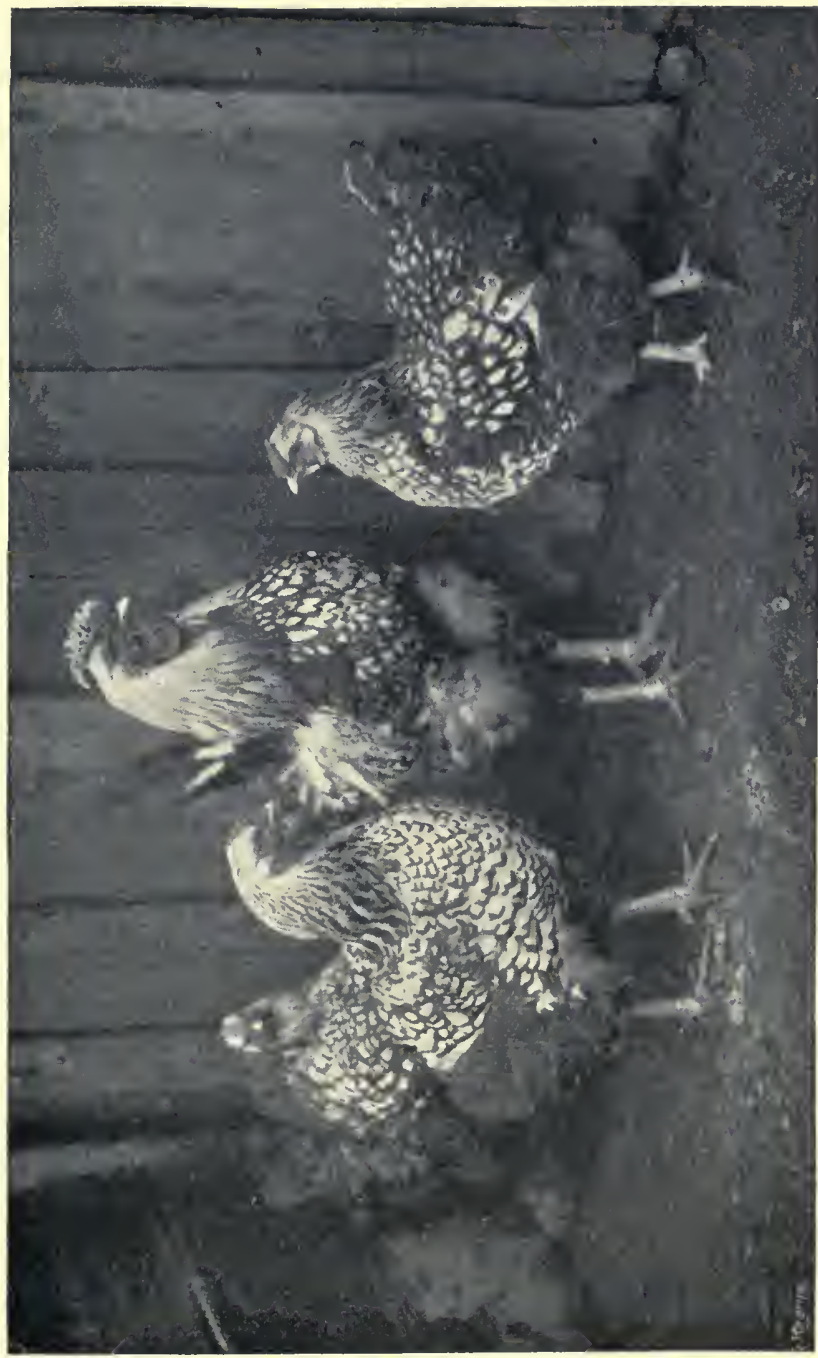

量 
stands poultry, can make his rent with a few head of poultry if he have one of these moveable fowl houses with a wire run attached.

By moving, every spring and winter, his house and wire run on to a fresh strip of ground, he can keep his garden well manured, and by placing his birds on fresh ground can keep them healthy.

And this method of manuring his garden is a great consideration to the cottager, because of the difficulty of obtaining manure in the country.

Manure in the country is a very precious article. The farmers around want all they can make, and in many cases much more than they can make, and no money can buy it. So everyone in the country, who grows anything, must make his own manure.

The manure made by a cottage pig' and poultry will keep an. ordinary sized cottage garden in good heart, and force the ground to yield its best.

It is useless to try to farm, or to garden, without manure.

To keep the ground well dug and noved, clean and clear of weeds, and wisely manured, is essential, if a good crop is to be grown.

And to-day it is only good crops that pay for their growth, whether these crops be grown in cottage garden or in large fields.

To force the acre to produce its best, and to fatten beasts and poultry on the lowest cost, is 
the secret of any success in dealing with the land, whether the holding be large or small.

\section{Do Fowls Pay?}

By close observation, careful selection, and by experienced management fowls can be made to pay, but not otherwise.

The first rule is to obtain a strain of poultry suitable to your land, and suitable to supply the wants of the market closest to you.

If you wish to produce eggs alone, then you must, in the first instance, obtain a laying strain that do not want to sit. Then your hens must lay eggs at a time when eggs are scarce and dear, namely, in the winter and early spring.

To obtain these early eggs your chickens must be hatched out early in the year, so that they will begin to lay during the winter and spring months. This of course means a great deal of care and trouble. But that care and trouble will be repaid by the extra price that the eggs laid in the cold months will fetch.

Then, after you have obtained a good laying strain, you must, in addition, and this is important, still further improve the laying powers of your birds by only "sitting" the eggs of those hens that lay the greatest quantity of eggs.

By only sitting the eggs and rearing the chickens of your best laying hens, and, season by 
season, carefully following out this law of selection, it is almost impossible to say to what pitch of egg-laying perfection in a few years your hens may reach.

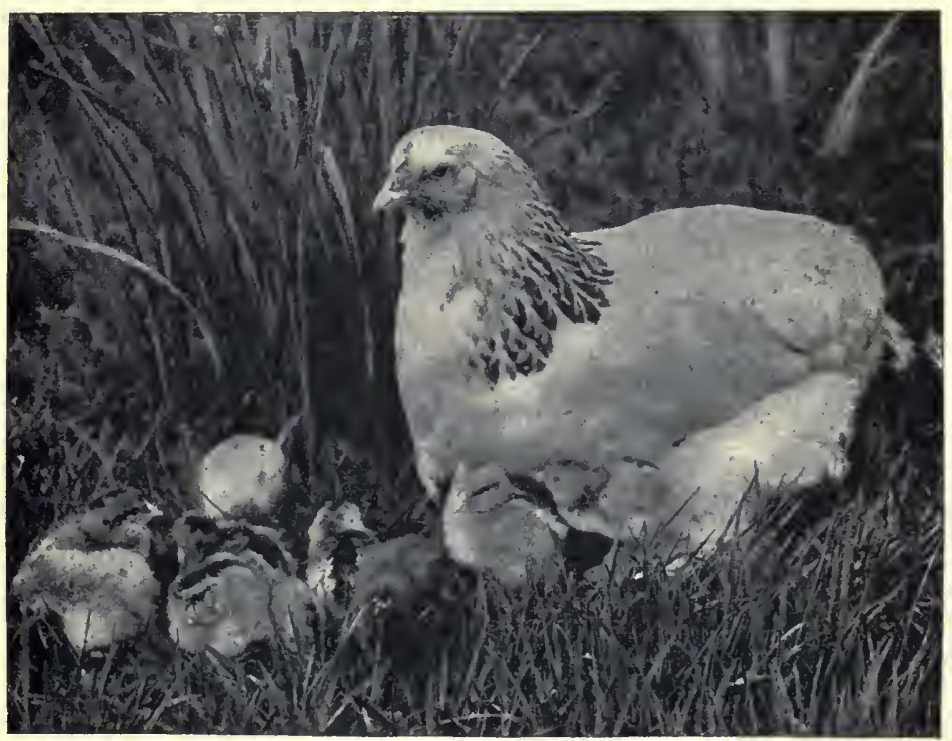

LIGHT BRAHMA.

It is considered a good average for an ordinary hen to lay 100 eggs per annum, but by carefully following out the law of selection in the manner just stated, strains of hens have been reared that lay 150 to 200 eggs per annum.

The hen that lays 200 eggs costs no more to keep than the hen that lays 100, and if by care 
and trouble these 200 eggs are laid mostly during the cold months, when eggs are fetching $2 \mathrm{~d}$. and $2 \frac{1}{2}$ d. each, then you can at once understand how egg production can be made to pay.

It is said that, to obtain the best egg-laying results, no hen ought to be kept longer than two years. After she is two years old she falls off in the number she lays, although the eggs she does lay are probably larger and better flavoured.

The cock should be changed every two years, and obtained from a strain at a distance which is not closely related to your hens, and you should try to get him from a breeder following out the same rules of careful selection as yourself.

Here is another important point to be considered. Supposing you possess a well-bred strain of hens, and by your own selection each hen has reached a power of laying a much greater quantity of eggs than the usual hen lays, then your strain becomes noted and valuable and can be sold at fancy prices.

It is far more profitable to keep a few hens, on sound business and scientific principles, than to keep a much greater number when these principles are neglected.

Also be careful to collect your eggs every morning, so that they are clean and free from spot and stain.

All agricultural produce that is sent to market 
in a clean and fresh condition fetches a better price than produce that has been marketed with less care.

It is also important to grade your eggs, so that the eggs in the basket look spotlessly clean, and are as nearly as possible of the same size and colour.

An even basket of eggs fetches a better price than a basket containing eggs of all sizes; shape, and tints of colour. A few dirty, ill-shaped eggs in a basket will bring down the value of all the better eggs that a basket may contain.

The weakest link of a chain is the test of a chain's strength, and a basket of eggs is valued by its worst looking eggs.

\section{The Best Position and the Best Food.}

As it has been said, a light, dry, sandy soil is the best soil for rearing poultry; and moveable houses that will hold about twenty-five birds are the best means of housing poultry.

The moveable houses should be placed facing south-west, in a dry situation, on the side of a hill for choice, so that the fowls can get all the winter sun, and obtain shelter from the north and north-east winds, and also shelter from the hot summer sun. Plenty of dry earth and ashes, for the fowls to dust themselves in, should 


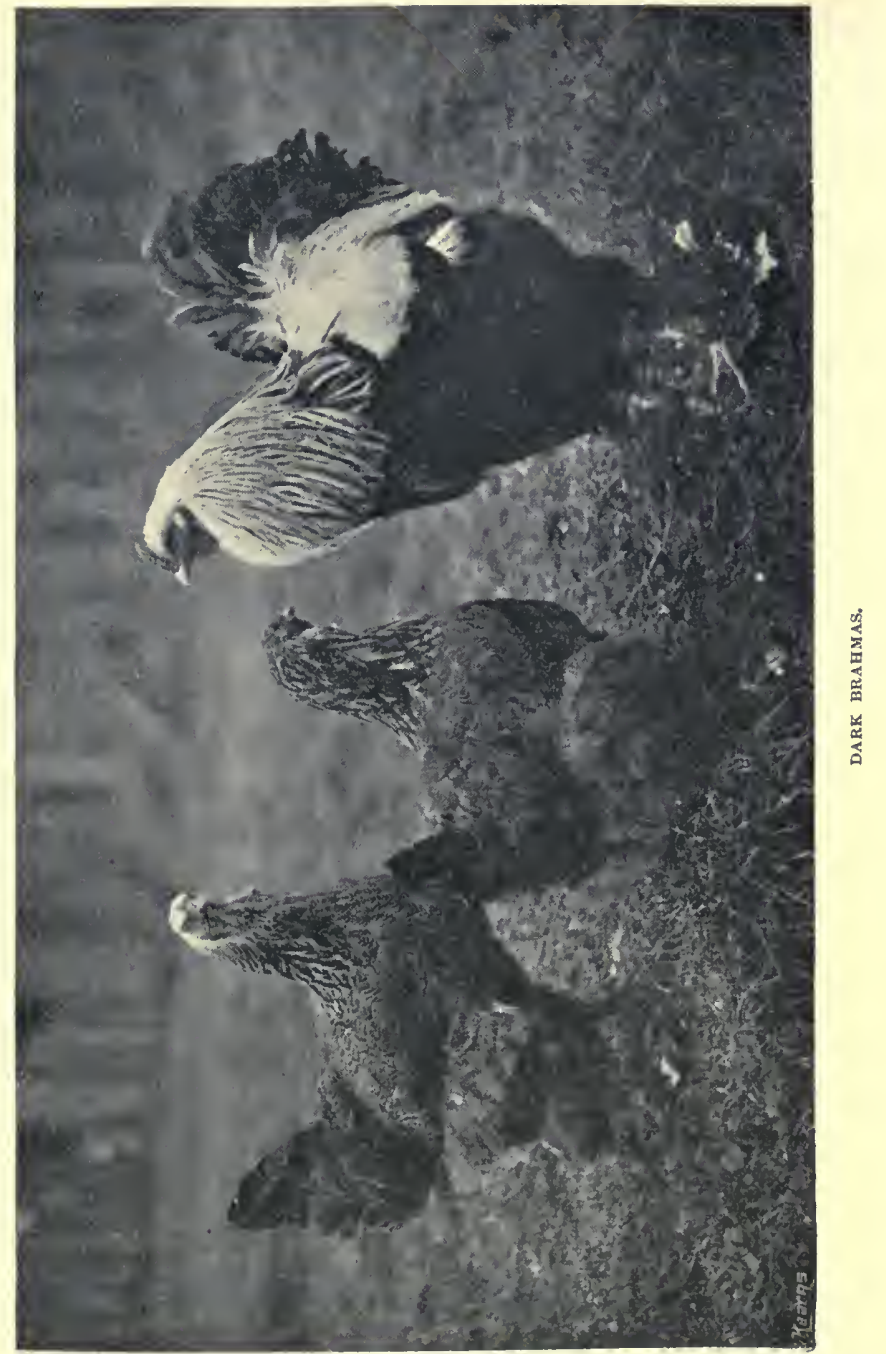


be placed in the shelters that are always underneath the most improved and suitable houses.

If the hens are to lay well, they must not be overfed. The food ought to be well seattered, not placed down in heaps, so that the birds are compelled to move about in searehing for it.

If the birds have an extensive run, twice a day is often enough to feed them; directly they are let out of their houses in the morning, and again, just before they go to roost.

For summer feed there is perhaps no better food than erushed oats in the morning, made somewhat stiff with a little water, or better still with a little sour milk that has been left over from the previous day, and for the evening meal, erushed oats, given plain. Wheat is also a good summer grain.

In cold weather, when the fowls require warmth, or when you want them to fatten quickly for table, give them a little maize.

For those who keep poultry on a small scale, all the odds and ends from the table, leavings from the plates and larder, seraps of meat, bread, potatoes, all mixed up, will lighten the expense, and will help the fowls to lay and look their best.

If your fowls eannot obtain a supply of grass, then grass and green stuff must be provided, for green stuff gives the eggs a rich flavour and helps to keep the birds in good health. 
A plentiful supply of fresh water is necessary to the health of all animals and birds, and especially is this necessary with poultry. Open vessels and saucers cannot be recommended, because the water is soon made dirty by the fowls treading in it, and leaving their feathers in it. An inexpensive block-tin cylinder, with a lip attached at the bottom of the cylinder, is a good system. No sooner is the lip emptied of water than it fills itself again from the cylinder that is above it with a fresh supply, and the eylinder is so constructed that while the lip is always kept filled, the water will not run over.

\section{How Fowls Digest Food.}

A fowl takes in its food by its beak, thence it passes down its gullet into its gizzard or stomach. In its stomach the food is partly broken up or digested, and lastly it passes into the intestines, where digestion is completed. The blood then takes up and circulates this digested food, and builds it into the fowl's bone, fat, tissue.

In the gullet there is a large bag called a crop. Large quantities of food are taken in and stored in the crop, but no digestion takes place there, the food being simply stored and softened by the bird's saliva. 'The bird then digests the store in its crop at leisure. 
You can understand when the wild fowl were surrounded on all sides by enemies it was far safer for them, when they did find food, that it should be swallowed at once and digested at leisure in some place of safety.

If they had to pick their food and chew it as they took it, they would be more exposed to danger, and would run a greater chance of being killed by their enemies.

For the same reason, namely, as a means of safety, cows, bullocks, antelopes, and sheep developed, when in their wild state, a formation of stomach that enabled them to rapidly take in a store of food, and then retiring to a place of safety, quietly digest it, chew it up at leisure,"chewing the cud," as it is termed.

The gizzard of a fowl, as you know, is a large, fleshy, thick substance supplied with two horny pads; these horny pads rub against each other and grind the food just as mill-stones grind wheat.

Fowls swallow small stones to help these horny pads to grind their food more thoroughly, and therefore, if the run does not naturally possess a supply of the necessary small stones, the poultry-keeper must supply them. The gizzard and the stones do the work of teeth.

A larger number of poultry ought to be reared in this country, and a great many more eggs 
produced. To do this, the keeping of poultry must be conducted on business lines. What is so essential is, that there should be a regular houseto-house collection of eggis and poultry, by some central store, worked by the pcople who supply it, and where the supplies could be graded, properly prepared, and packed for market.

Extensive buyers of agricultural produce require large quantities of produce of a uniform quality that they can depend upon, and this want can be best met by co-operation amongst the producers themselves.

Many a careful cottager who has taken the trouble to rear the best sort of poultry, that lay when eggs are scarce, or that fatten readily, or those that combine numerous egg production and early flesh production, and who has taken the trouble to keep no hen that does not pay for the food she eats, has, with a few hens that have been reared on a very narrow strip of garden, more than paid the rent of his cottage and garden.

The cottage hen and the cottage pig has, times without number, made the difference between living in comfort and living in poverty. 


\section{BEES.}

There are three reasons why a cottager, whenever possible, should keep bees, provided, of course, he knows something of their ways and habits, and how to treat and handle them.

(a) Because honey is useful and delightful as a food, and especially nourishing and warmthgiving to growing children.

(b) Because bees increase the quantity of fruit of a garden and district.

(c) Because bees are profitable.

\section{Honey as Food.}

It has been proved that a certain quantity of pure sugar is necessary to the formation and strengthening of a child's bone, and also that it gives warmth and nourishment to its body.

A certain amount of sugar has also been found useful in feeding farm animals. Horses have borne the strain of long and tiring eampaigns the better for having been fed with a certain amount of sugar each day.

Starch forms three-fourths of the bread that we eat; this starch must be digested, must be converted into liquid sugar, before it can nourish our bodies.

Now honey is the purest and most nourishing 
form of sugar, and therefore a child by eating a moderate quantity of it can obtain heat and power with the least work to its digestion.

There is probably no better breakfast for a child than a cup of milk, and good home-made bread baked from second flour, upon which is spread a liberal layer of honey.

Honey is also most useful in keeping the stomach of a child strong and in good order.

It is said that there are tons of adulterated honey sold in this country that produce sickness and a general distaste for honey itself. Hence the importance of keeping one's own bees, or of getting honey where we know that it is pure.

\section{Bees and Fruit.}

By very careful experiments it has been proved that a far larger yield of fruit has been obtained where the bees have been at work amongst the fruit-blossoms, and that clover has produced a greater quantity of seeds where the bees have been at work.

At an experimental station at Oregon, in Canada, a number of peach trees were forced under glass in November. One tree was protected, so that the bees could not get at the blossoms. From that tree, when the stones began to form, all the fruit fell off. On the other trees, where the bees had worked freely, 
the fruit was so abundant that it was necessary to thin out severely, in order that the fruit that was left might have room to swell and ripen.

Professor Cook of the Michigan Agricultural College made the following experiment.

He covered up ten heads of white clover, and ten heads of red clover, so that the bees could not get at them. He left the same number uncovered. When the clover heads were ripe, they were examined. Not one seed was found in the covered red clover heads, but 191 were found in the uncovered heads. Three seeds were found in the covered white clover heads, and fifty-four in the uncovered white clover heads.

Therefore, not only are bees useful in giving us wholesome, nourishing food, but they are useful in increasing the quantity of the fruits of our gardens and orchards.

\section{Bees, a Source of Profit.}

Honey to the amount of $£ 30,000$ a year is sent from abroad into this country. This $£ 30,000$ ought to go into the pockets of our people living in this country.

In England 200 sections of honey have been taken from one hive, 135 of which were sold at 1s. each, and 65 at 1s. $6 \mathrm{~d}$. each. This of course is a very exceptional yield and a very exceptional price. It is a golden rule not to decide 
matters on exceptions but on averages. And the average yield in England is about 60 lbs. per hive, a low average price being $6 \mathrm{~d}$. per lb. ; this gives 30s. profit a year from every hive of bees.

The wax also fetches a ready sale, and a swarm will sometimes fetch a good price in the market.

Many working men who understand bees have made $£ 6$ to $£ 8$ a year net profit, and we have heard of one working man who made $£ 29$ profit from his bees, and one lady who netted $\mathfrak{x}^{2} 10$ s. from one hive.

\section{Who Ought to Keep Bees?}

Another golden rule, that the experience of men and women in all ages has proved to be true, is this, that if we are to be successful and to make an undertaking pay, we should know something of that undertaking before it is attempted. Especially is knowledge necessary if bees are to be kept with pleasure and profit.

Knowledge and practice give confidence, and when you get confidence, the bees seem to know it,' and when you go near the hive and handle them they do not get frightened or angry, and therefore you have less chance of being stung. But if from ignorance, or want of practice, you are nervous and clumsy, you will have every shance of being badly stung.

It is the same with every animal about a farm. 
An ignorant, nervous person has more chance of being hurt by the animals, than a person, who, from knowledge and sympathy, has nerve and confidence to handle and treat the animals with kindness and firmness.

There are some people, also, who suffer dreadfully from the sting of a bee, and such are of course unfitted by their constitution to keep bees, and therefore they ought not to attempt it.

If you are thinking of keeping bees it would be wise to visit one of the district agricultural shows, where bees are exhibited, and learn all that the show can teach; or consult somcone in the district who keeps bees, and who would gladly give you the benefit of his experience.

Begin in a small way at first, keeping only one hive, and then if you find that you can manage the one colony successfully, and that they are profitable, increase your stock gradually.

Also be careful that your hive is the British Bee Association's standard size, so that all the parts will fit each other, and will also fit every other part of any other hive that you may introduce.

If you buy a second-hand hive, be careful to make sure that there has been no disease amongst the bees that formerly occupied it, otherwise your bees may catch the disease. Unless you can be sure of this it is best to run no risks but to buy a new hive. 
Bee-keeping requires no physical strength. just a little knowledge, a little patience, a little pluck and presence of mind, a little painstaking day by day, a little sympathy for the wonderful wisdom, and hard, self-denying work of the bees, and then after a time success is sure to come.

Bee-keeping means work in the open air amidst sunlight and flowers. It helps the power of observation, it gives health and nerve, and above all, it must teach reverence for the Great Power that has endowed one section of His work with so much wisdom and untiring industry.

\section{Honey.}

If you don't keep bees it is so much waste, because the flowers contain the sweet nectar that the bees make into honey, and by their shapes, colours, and scents, are ealling for them to come and gather it. A bee's visit is necessary for the vigour and life of plants.

Very beautiful is the colour and shape of flowers, and very refreshing is their perfume. They add to the refinement of our mind and give beauty to a house and garden as nothing else can or does. But in the first instance they were not meant for that. All their various tints of colour, their differing shapes, their shades of scent, were meant to attract the bees and other insects.

Their brightness, shape, and perfume are 
devices to show a bee where its food is to be found. By their silent beauty and sweet particles of scent, the flowers call to the bee and say, "Come to us, and you will find amidst our colours, sweet nectar which is food for you, and which you can store up for the winter, and live on when our summer life is at an end."

And the bees, with that wonderful instinct which at present is beyond our knowledge, understand these signals of the flowers.

The bees also confer an enormous benefit on the flowers by their visits. It may be said that bees and flowers form a mutual benefit society. Without the bees and insects the raco of flowering trees and plants would weaken and probably die out. Without the Howers the bee would starve and die.

For while the flowers are feeding the bees, they dust the bees all over with their yellow pollen grains, and in visiting another flower the bees carry these pollen grains to do the work of fertilisation, or eross-fertilisation, as it is termed.

'This cross-fertilisation keeps up the vigour and beauty of future plants and trees.

By the great and primal law of mutual dependence, everything, while seeking its own life and advantage, adds to the life and advantage of another. Self and non-self act and react. 
Nothing is independent of another, everything is dependent on another. The welfare of the part means the welfare of the whole. The welfare of the whole means the welfare of the part.

As you read on you will see how the bees illustrate all this.

\section{Three Things or Products from the Bee.}

Honey, which it obtains from the sweet neetar of the flowers,

Wax, which it makes underneath its body and with which it builds the combs,

Propolis, a kind of long, waxy thread, which it uses to fill up and make good all defects in the comb,

Pollen, with which the larvae are fed.

\section{HONEY}

is nectar that the bee obtains from the flowers, and it is largely mixed with water. In the honey stomach of the bee this water is separated from the honey, and the pure honey is then stored by the bee in the cells of the hive.

\section{WAX}

is formed by the bee, underneath its body. In the hive, the bees hang on one another in festoons, like a plumb line, and with their front legs and mouth convert the wax into ribbons, and with these ribbons of wax build their combs. 
It is said that wax is a waste product, or secretion, the waste of the honey, and it is formed on the under side of the abdomen, where it hardens into fishy-like looking scales.

A bee has to consume an enormous amount of honey to make wax; it is said that it has to eat 13 to $20 \mathrm{lbs}$. of honey to make $1 \mathrm{lb}$. of wax.

\section{Pollen.}

The bee gathers pollen from the stamen of flowers by means of its front legs and the hairs of its body. In order that it may lose no time when on the wing, the pollen, that is all over its body, is moved by means of its mouth into two hollow places, in the hind legs, called pollen bags. When it has a load of this bright yellow pollen as large as it can carry, it flies off to the hive, and there unloads into a cell, while another set of bees pack it away carefully till the young, or larvae, require it for food.

Watch the bee when it first issues from its hive, on a summer morning; intent on its day of busy and continuous toil. If it begins its search for honey on a sweet-pea, it will go on with a sweet-pea. If with a dandelion, it will go on with a dandelion.

'Then, if you can, watch it settle with the utmost lightness and grace on a flower, and with its feet force the petals apart, so that it can get 
its head within reach of the sweet nectar, and with its long tongue, that has a sort of brush at the end, lick up into its mouth the sweet juice of the blossom. Not, however, to eat it all itself. No ! Its instinct tells it that it must principally work for others, and so it passes the nectar into a little sack called a honey-bag. When this honey-bag is full, off the busy little thing flies, to store in its hive what it has collected.

While searching for honey, its hairy legs and body will collect a quantity of yellow pollen, which it packs away in the hollow of its hind legs, and which is required as food for the larvae.

But all of this pollen is not packed away in the legs and carried home. Some sticks to the body, and on its round of visits the yellow pollew grains are carried to other flowers and do the work of eross-fertilisation; a work that adds to the strength and beauty of the flower world.

So you see the pollen feeds both bee and flower.

In a bee community no shirking, skulking, or inferior workmanship is allowed. Every nember of the society must work at full pressure and to the utmost of its power.

Not only must the working bee get food for itself, but, more important, it must collect food for the young and for its fellow bees.

It does not spare itself. With an intentness 
that we may well imitate, it works without pause or hesitation. It minds not and meddles not with anyone else's business. Into its own life-task it pours out all its strength, and then, when it has done its very best to lay up a store for future generations, at the end of some six weeks, weakened by its labours, it is thrown out of home to die.

As with bees so with everything else, what we know of them is very little compared with what we do not know. We are all of us on a voyage of discovery.

\section{Different Works.}

If you look into a hive you will see perhaps 20,000 honey-gatherers or workers, one larger bee surrounded by a dozen or so of others. This larger bee is the queen bee, whose work in life is to lay eggs, as many as 2000 eggs in a single day. There are a few hundred that apparently do no work; these are the males or drones.

The swarm, or family, in a hive, consists of a queen or mother bee, 20,000 or more workers, and about 500 to 1000 drones.

The queen is the mother who lays eggs. The workers are undeveloped females who do not lay eggs, but do the work of eollecting and nuking honey and wax, building the combs and forming the cells in which are stored the honey and pollen, 
feeding the young, and protecting the hive from the entrance of enemies.

A bee's life passes through four stages. First the egg, then the larva, or eaterpillar, then the pupa, or ehrysalis, and lastly the imago, or perfect insect, namely, the bee.

The life and strength of the eolony depends on the mother bee. If the mother bee, after having laid a few eggs, is killed, or gets driven away, the workers search for her everywhere, and if after a time they cannot find her, they give up their search and take steps to produce another queen in her place.

This they do by preparing an extra rich food, called "royal jelly," and feeding some of the larvae upon it. In some mysterious manner this "royal jelly" converts the larvae, which would otherwise turn into workers, into a queen bee, and then the colony, knowing that their future is safe, cease from their agitation and each department of the community settles to its own work.

A queen will live four or five years, but each year she lays fewer eggs. Therefore it is of the utmost importance that the queen should be young and healthy.

Keepers of bees require a quiet bee to handle. - a busy bee that will eollect and make the largest and purest quantity of honey, a bee that will make good combs and take rearlily to its hive, 
and a bee that will tend the young well and is courageous in defending its hive.

Therefore, keepers of bees select their queens from that strain of bee that comes the nearest to this standard.

Selection rules here as it does with all else connected with the land, if everything is to be made the best of.

\section{No Mercy.}

There is no merey in a bee community. The member of the community, that is no longer of use to its fellow bees, is cast out to die.

When the queen bee does not lay enough eggs, to make sure that the community can go on in sufficient strength and sufficient numbers, she is cast out of the hive.

About the middle of April the drones fly about. At the end of the summer, when their service is no longer of use to the community, the workers cast them out of the hive and leave them to perish.

The life of the worker is about six to eight weeks. Every moment of their working day during those few weeks, is probably occupied; they do not seem to economise their strength, and so their life is soon over. 'The younger and more vigorous oncoming workers turn the wornout workers out of the hive to die. 


\section{Work for Others}

is the great prineiple of the bee community. If you are of use, well and good, but if you are old and worn out and can no longer do what you once could, we can't consider your past service, we have neither the time nor room for hospitals or places for aged bees, out you must go.

"For the individual bee must be sacrificed because it is more important that the race of bees should live on in prosperity and strength than that you should live on to become a useless burden on us. If you, the old, inferior, and useless to this community, were to live on, we should not have a sufficient number of vigorous workers to build the combs, manufacture the wax and honey, rear the young and protect the hive. It takes us, the vigorous and young, all our time to keep the race going."

\section{Parts of a Bee.}

It may be said that a bee is divided into three sections, the head, the thorax or middle, and the abdomen or hind part. These three different seetions are joined, but there is no internal skeleton as there is in the animal body.

A bee has six legs and four wings, and breathes by tubes that extend along each side of its body. These tubes are fringed with hair in order to 
keep out the dust and other particles. It feeds the young, which at first are quite helpless, upon pollen or upon pollen and honey mixed.

In the front part of the hind section or the abdomen, is a department ealled a honey sac, in which the nectar from the flowers is collected and made into honey. Underneath the abdomen itself are places that collect and hold the wax which looks like fish seales.

The first joints of the lind legs are widened and hollowed out, thus forming receptacles to carry pollen, which are called pollen baskets.

The mother or queen bee is much larger and longer than either the drone or the worker, by reason of the increased size of the abdomen.

As the queen does not leave the hive except at the time of swarming, and does not collect honey and pollen, her wings and tongue are shorter than those of the workers, and she has no place in her hind legs to carry pollen.

\section{The Sting.}

As the queen has her faithful subjects to defend her, and therefore has little or no need to defend herself, she rarely stings, and when she does, she does not inflict the same pain as that caused by the sting of a worker, because her sting is quite straight, without a barb at the end.

'The sting of a worker is barbed at its end, so 
that, when once inserted, it cannot be withdrawn, but must remain where it is.

In consequence of this loss of sting the worker dies, which proves that the sting is only used in great emergencies or self-defence, and is not used for the pure malicious pleasure of inflicting halim.

As the sting enters, the bee sends down a drop of poison ; this it is that eauses the inflammation and pain.

The smell of the poison is very strong, and seems to infuriate the bees that come within its range. They at once fly round and try to sting the unfortunate person stung; and this is probably the reason why people get so badly stung, who, from elumsiness or want of knowledge, frighten the bees.

One bee, thinking the clumsy and ignorant person an enemy who wants to do some harm to the community, stings him; the smell of the sting evaporating, excites all the other bees, within smelling distance, to sting in their turn. Of course such a combination of stings is a most effectual method of defeating and overcoming an enemy. So the sting of a bee and smell of its sting may be a signal of alarm, a signal of defence, a signal for the other bees to attack and overcome a common enemy. 


\section{The Life History of a Worker.}

A worker egg is laid in a cell by the queen bee. In three days it is hatched out in a larval or caterpillar condition. As a larva it is fed on pollen, or pollen and honey, by the younger bees, told off for that purpose. At seven days old the larva, having grown to its largest size, is capped over with a coating of pollen and wax, which is porous, so that the air can get through it. At the end of twenty to twenty-one days it comes forth, a lightish coloured, downy little bee.

The first twelve hours of its bee life are spent in gathering strength for the work that lies before it, and then it begins to feed the larvae.

When old and strong enough it goes forth from the hive to gather pollen for the young, and honey that it stores in the hive against the cold of winter, when the flowers with their stores of nectar have disappeared. For some six or eight weeks the busy thing works on without intermission.

Within a few hours of emerging from the cell, unceasing labour is the worker's portion, till the great strain of incessant work weakening its powers, it is no longer of the same use to the community, and so the younger and more vigorous bees cast it out of the hive to die. 


\section{Swarming.}

In the spring of the year, when the sun gets a little warm, the queen bee lays a considerable number of eggs, which in due time add considerably to the colony. The hive in consequence gets overcrowded and overheated. The bees then seem to know that, in order to continue the race of bees and for the benefit of the colony, some of them must seek an abode elsewhere. After certain preparations the queen bee and a number of other bees fly out of the door of the hive, and with wonderful rapidity rise in the air and hover for some time as if awaiting stragglers. At last, having selected a rallying point, generally a tree, or some bush, the leaders alight and are at once joined by the main body, till the whole number is collected in one mass of hanging, buzzing bees.

The swarm having rested for some time at their first resting-place, and having collected the whole of their number, soar again into the air and shape their course with great speed to the spot selected by their leaders for their future home. In this spot, - very often the hollow of a tree or some equally protected spot-they make their combs, gather honey and rear broods, and go through the same round as the colony from whence they came. 
The parent hive by this migration has been thinned of a number of its inhabitants, but still there are sufficient left to rear the young brood, which, arriving at maturity, quickly makes good every defect.

'The young queens being allowed their liberty one after another conduct fresh swarms.

As long as the increase of population renders the hive uncomfortable, successive swarms are sent off. Their number depends on many things, such as an abundance of flowers, warmth of climate, and size of hive.

A French Consul in South Carolina found in a wood, a stock of bees which had been robbed of their honey and wax by the natives. He carried the stock of bees home in his hat and placed them in a hive in his garden. He obtained from this hive eleven swarms before the end of the autumn, and these eleven swarms gave off other secondary swarms, so that by the end of the year he had twenty-two hives stocked from the one he had carried home in his hat.

In this country a hive sends off only two or three swarms in the summer.

A prudent bee-keeper is satisfied with one swarm to stock a fresh hive or to sell, returning the rest to the original hive, which would otherwise become very weak. 


\section{Position of Hive.}

Most bee-keepers now keep the pure Italian bees; they are larger than the small black English bee, and, being less irritable, are much less trouble to handle.

Sunshine, and especially that of the morning sun, is most essential for the health and warmth of all life in the country, whether plant life. animal life, or human life. Bees are no exception to the rule; therefore the best position for a hive is facing south, with a point or so of east in it.

During the few weeks of hot weather it is arlvisable that the bees should have some sharte. If this camnot be managed, the hive must be painted a light stone colour, with a white roof.

Do not place the hive close against a wall. and have the front, where the bees enter the hive, dry and firm and clear of grass and weeds. This will be of great service to the bees, for often, when they are coming home and are about to enter the hive heavily laden with honey, the wind will blow them on the ground, and if there is damp grass at the entrance they will get shilled and, being unable to enter the hive, die.

\section{Winter Food.}

If all the honey that the bees have collected during the summer be taken from the hive, they 
must be fed, but fed very sparingly, during the winter.

The following is a good recipe :--5 lbs. of best sugar placed in a preserving pan ; add $2 \frac{1}{2}$ pints of water, place the pan on the fire, and stir. As soon as the sugar is dissolved the food is ready. Do not let it boil.

Water is necessary for bees, especially in the spring-time. Let the water be placed in shallow vessels so that the bees can drink without fear of drowning. It is as well to place pieces of cork in the water, from which the bees can drink.

\section{Enemies.}

The sting of a bee does not seem to affect ducks in the slightest degree. They will wait at the entrance of a hive and gobble up the bees as fast as they come out.

Those beautiful little birds, the tits-the great-tit, the blue-tit, and the cole-tit-will often kill bees on the wing, and when dead will eat them.

The red-backed shrike-very sensibly called the butcher bird-will catch the bees, and then will stick or impale them on any bits of wire or thorns that may be near the hive.

Toads will watch at the entrance of a hive 
and lick up any bees coming within reach of their long tongue.

Mice are very destructive; they will get into a hive and consume everything wholesalecombs, bees, honey.

Wasps bear cold better than bees, so in the autumn, when the bees are drowsy and their sentinels weak and not fit for a fight, the wasps will force their way into the hive and make sad havoe with the store of honey.

Any wasps that you see flying about in Mareh, April, or the beginning of May, are queen wasps seeking places for their colonies; so if these queen wasps are killed, their numbers are diminished by thousands in the autumn.

It should, lowever, be borne in mind that wasps do a vast deal of good in killing flies, insects, and purifying decaying matter.

It is a serious matter to interfere with nature. Over the long past the natural balanee, or order, has been struck so evenly, and man's knowledge of the natural order is so limited that he often does himself more harm than good when he attempts to interfere with the balance.

The greatest enemy, however, of the bee-keeper, far beyond those that you have read about, is what is called "the honey dew."

This is a sugary, glistening substanee made by that eurse of the garden, an insect called the 
greenfly. It is sometimes so abundant that it will drop from the leaves of trees like rain, especially from the leaves of the lime tree.

This honey dew is, to some people, very nauseating, and is of no use as food for the young bee. It is very difficult to detect. It has not the rich colour of honey and looks as if soot had been sparingly mixed with sugar or syrup.

With all their wonderful wisdom it is curious why the bee should be deceived by the honey dew. Perhaps it serves a purpose we do not understand.

The prime object of a bee, in collecting honey, is to gather food for its young, and to collect a store of food for that season of the year when it cannot be gathered outside the hive. 


\section{PART II.: WILD LIFE OF THE COUNTRY}

\section{ANIMALS.}

Slowly but surely all the wild animal life of this country is disappearing.

How sad it is. A species of animals or birds once thoroughly exterminated is gone for all time. A piece of God's handiwork that can never be replaced.

How much more interesting is the country if we occasionally see a bit of wild life, moving and acting without restraint, except the restraint that its own natural laws, learnt from the experience of its aneestors for the well-being of its race, have imposed upon it.

If these wild animals did more harm than good to the agriculturalist, the writer feels that his appeal for their preservation would be useless. But careful observers have come to the conclusion that most of the wild life does the agriculturalist more good than it does him harm.

The polecat, the stoat, the weasel, the fox, the badger, on the whole, do the agriculturalist more 
good than harm. Therefore why kill these animals? Why stamp them quite out of existence?

If you see a wild thing, why not let it go? It is more beautiful alive than dead. It is cruel and selfish to kill whenever you get the chance.

If the wild animal or bird does more good than harm, if its wild life adds to the charm of the country side, why not let it live its life?

Give some other human being a chance of feeling the pure pleasure that arises from observing its ways and habits.

It is no easy matter to observe accurately the ways and habits of any animal or bird that is living its own free life.

It requires sympathy, patience, self-control, trained powers of observation, and a certain amount of knowledge.

\section{The Dog Family.}

The dog family, of course, includes all the domesticated dogs; the wolf, that is no longer seen in this country, and the fox, which is the only member of the dog family that is found wild.

Fox. - The fox lives in an underground dwelling dug out by itself, or else it occupies a deserted badger-burrow.

It is one of the prettiest sights to watch a litter of cubs of an evening come out of their 
underground dwelling for a game of play. Such intelligent little things they are!

A fox will catch mice and field voles as scientifically as a cat; and when a vixen has cubs she will bring home five or six in her mouth.

Of course a fox kills hares and game birds, and will, when it gets a chance, make a raid on your poultry if you are so foolish as to leave them out at night in the open, or let them roost in shelters exposed to any bird of prey, wild animal, or vermin that may come along. But if they are locked in one of the modern moveable poultry houses, which they should be, nothing can disturb or hurt them.

With wonderful sagacity and cuteness, foxes will not as a rule eommit theft, or do much damage in their own immediate neighbourhood, for fear of betraying their hiding-place.

There is no disguising the fact that a fox will do a certain amount of harm, but, on the other hand, it does a deal of good by catching an enormous number of rats and mice, and eating cockchafers, worms, and snails.

Careful observers and students of natural history now tell us that, on the whole, the good a fox does outweighs the harm it does.

"Fox-hunting."-If the fox were exterminated the best hunting in this country would cease, 
and the loss to the country districts in consequence would be enormous.

A pack of fox-hounds enriches and makes more lively any district where it is established. It fills houses; it employs labour; it causes large sums of 'money to be spent in country districts that would otherwise be spent in the town or abroad. The farmers sell hay, straw, oats, to the members of the hunt. Horses are bred, reared, and sold as trained hunters by farmers, and this in many cases helps considerably towards their rent.

Fox-hunting brings all classes of agrieulturalists together on terms of greater equality than any other sport does. Pure merit is recognised-the merit, namely, of riding straight when necessary, - the merit of pluck and judgment, of sparing your horse when necessary, of not riding over growing crops, or leaving gates open, not jumping and breaking down fences. when the dogs are not running, and, when they are running, doing as little damage as possible.

All this requires skilful horsemanship, judgment, control, good temper, and knowledge.

Any man that possesses these characteristies, so essential to a good rider to hounds, is looked upon with respect and admiration by the rest of the hunt whatever his social position may be.

And any man, who is popular with all classes 
in the hunting-field, you may be quite sure is no bad man.

\section{The Weasel Family.}

The marten, the polecat, the ferret, the stoat, the weasel, are all connected, that is, they are

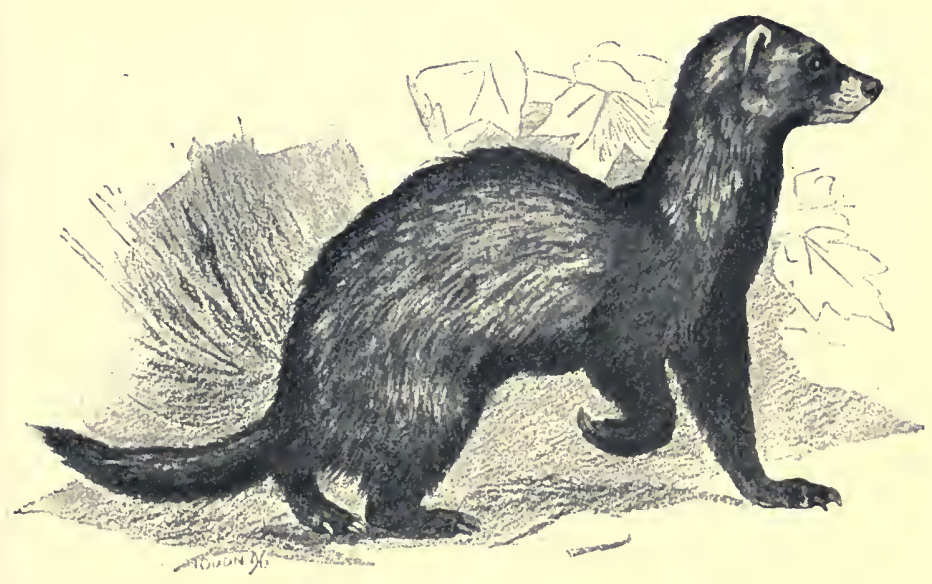

members of the same family, that family being called the weasel family.

Ferret.-The ferret you all know, so there is no need to describe it, and it can hardly come under the heading of wild animals, for it has been tamed and trained by man for the purpose of compelling rabbits and rats to bolt from their holes. It is said to be a short-legged variety of the common polecat.

Stoat, - The stoat is still found wild in 
England. Its body is about 12 inches long, with a long and slender tail with a black tip to it. The body is searcely broader than the head. Its colour is brown above and white below. It lives mostly in fields in the neighbourhood of plantations and woods. It is specially abundant amongst sandhills, because dry and warm land is the most suitable land for rabbits to breed and multiply.

It usually follows its prey, mice, rats, rabbits, and hares, at night. It is more useful than destructive.

Weasel.-The weasel is smaller than the stoat. Its head is larger and thicker than its slender snake-like body. It is a sharp little animal and easily passes through mouse-holes. Its colour is black and brown, with a white belly.

It feeds on field voles, rats, and water voles, young hares and rabbits, birds building near the ground, also eggs, which in some eases the weasel carries home under its ehin. It also eats lizards, blind worms, snakes and frogs. If it gets into the fowl-house it will do damage.

Because of the quantity of mice and voles it destroys, it is said to do far more good than harm.

A few years ago there was a plague of field voles in Scotland. These little animals devastated large areas of land in the lowlands of 
Scotland. The grass was bitten down and eaten away, and the land was honeyeombed with their runs. In eonsequence the pastures were much damaged, the sheep fell off in eondition, and the loss to the farmer was very great.

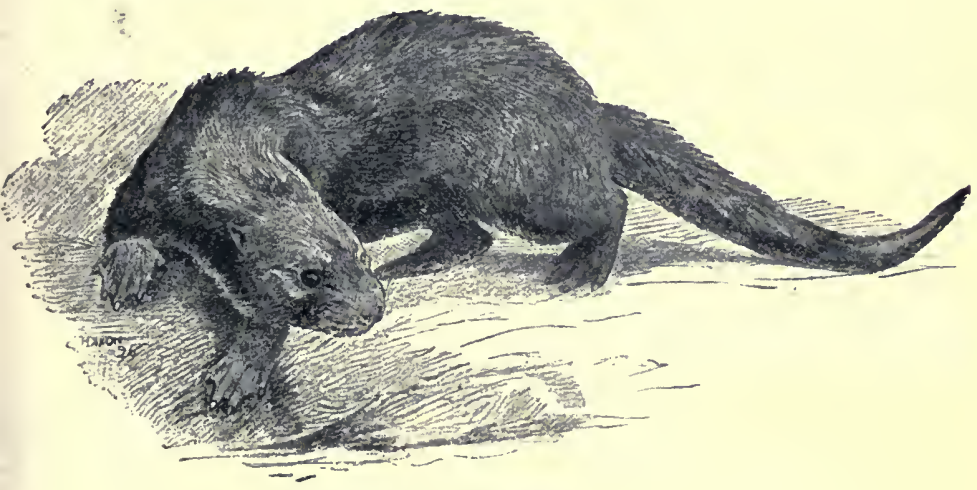

THE OTTER.

So serious was the plague that a board of inquiry was appointed by the Government. The board reported that one reason, if not the chief reason for the plague, was the destruction of magpies, stoats, weasels, kestrel hawks, and short-eared owls.

In consequence of the excessive crowding together of the voles, disease loroke out among them, and this thinned them down again.

Otter.-Body flattened; legs short, with webbed toes; snout rounded; ears short, which can be closed by a fold of skin; tail flat and 
pointed at its tip. Length of body 28 to 32 inches; tail 14 to 16 inches. Skin smoothhaired, showing dark brown above and below. Found on the banks of lakes, pools, rivers, brooks, where fish is plentiful. It catches water rats, ducks, geese, as well as their young, wild water birds, frogs, fish, cray fish, water insects. It is specially destructive of fish.

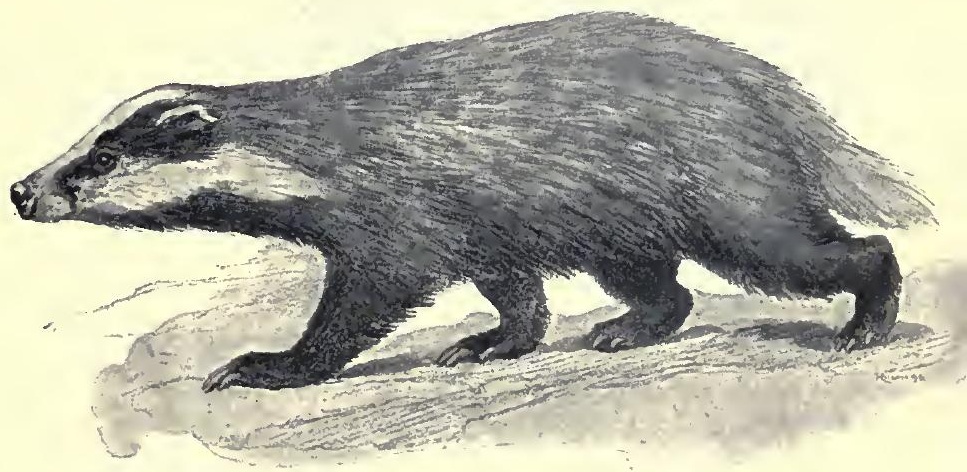

THE BADGER.

Badger.-Body heavy; legs short; toes with strong digging claws; snout pointed. Length of body, 3 feet; weight, 22 to 23 lbs. The burrow is very large; several passages, the openings of which may be 97 feet apart, lead to the exterior from which the animal comes into the open.

The badger only leaves its dwelling in the evening. It eats mice, birds which nest on the ground, especially their eggs and young, snakes, 
frogs, cockchafer grubs, earth worms, insects, also turnips, carrots, acorns, and sweet iruits. Although the badger is both harmful and useful, it is said to be more useful to the agriculturalist than harmful. It possesses great digging power, and in this respect is destructive, for it throws up young trees and plants by the roots. Although the badger does not hibernate, that is, does not sleep through the winter, in cold weather it sleeps for several days in succession, living on its own fat which it has stored up during its days of plenty.

\section{Insect-eating Animals.}

(1) Shrews. - These are small animals, in appearance something like mice, with slender soft-haired bodies, small eyes, and tolerably long thickly-haired tails. They are tremendous eaters, eating daily, it is said, more than their own weight of food, and destroying an enormous quantity of underground vermin. The common or lesser shrew is only about 2 inches long and kills in the cornfields, gardens, and woodlands a great quantity of noxious insects, together with their larvae, as well as snails and worms. Therefore don't kill the shrew.

Mole.-You all know the mole with its thick black shining body, short legs, and with forelegs broad and spade like, with its broad digging 
claws. Its eyes are small so that they can scarcely be seen. The mole has no external ear, but in its place there is simply an opening which can be completely closed by a fold of skin.

Wherever there are insects and earth worms and the soil is not too stiff, there the mole can generally be found. The soil must not be either too loose or too stiff, because if it is, the mole cannot dig into and make compact its dwelling and passages.

Whenever you see little mounds of loosely cast up earth you know that moles are about.

The nest is always found under a larger heap than usual, and mostly hidden very wisely under roots of trees or walls, but sometimes in the open field.

The nest is a nearly round dwelling chamber, softly upholstered with vegetable substance.

From this nest the passage or passages run to the mole's hunting ground, and may be 100 or $160 \mathrm{ft}$. long. The walls of the nest and passage are compact and hard, so that the earth will not fall in.

When the mole is catching insects in the soil by throwing the earth out, it digs or excavates a very rough passage, and by means of its long snout, tracks to some distance the insects, larvae, or worms, found in the soil. The mole takes no pains to render this hunting passage compact, as 
it does the sides of its nest and its permanent passage to its hunting ground, so it soon falls in.

The mole makes the passage to its hunting ground compact by pressing the earth tight on either side, and thus forcing a passage, instead of throwing it up above ground.

When, therefore, you see a depression in the ground, you know that underneath this depression there runs a compact passage made by the mole from its nest to its hunting ground, and when you see mole hills towards the end of the depression, you know that this is the area where moles are actually on the hunt.

The mole sleeps in its nest during the time it is not digging and searching for food. Three times a day it goes forth on the hunt for insects, each morning, mid-day, and before sunset.

It is said to devour daily more food than its own weight. And it eats wire worms, grubs, snails, earth caterpillars, mole crickets, and other earth inhabiting insects, as well as their larvae. It also eats earth worms, but the benefit of this is doubtful. It may do harm by rooting up plants as it makes its heaps, and these heaps are naturally a great nuisance in hay and corn fields.

Grass and grain suffer little, if at all, by the work of the mole. Other plants suffer more. Moles never gnaw plants. It does not fall into a winter sleep. It has three to seven young at a birth, 
and they are usually born during the months of May, June, or July.

Hedgehog.-When danger is near, the hedgehog, as you know, as a means of defence, tucks its head away and rolls itself into a ball, which is covered all over with hard, piercing prickles. It takes a dog "well up to the dodge" to cause the hedgehog to unroll itself so that it can be killed.

The hedgehog goes on the hunt in the evening, and during the day it sleeps in its hiding-place, which hiding-place is usually by the side of a ditch or hedge or under a. heap of brushwood.

It preys very largely on field voles, sometimes on eggs and small birds, lizards, grass snakes, adders, frogs, cockchafers and their larvae, field snails, earth worms, and sometimes for a change on fruit and juicy plant roots.

Bats.-It may surprise you to read that the bats which you so often see flying about so noiselessly of an evening come under the heading wild animals.

If you could dissect a bat you would find that the fore limbs, instead of being used for walking and running, have been converted into a flying apparatus.

You would see also that the bones of the forearms are of great length, and between the very long fingers and between the fore and hind limbs, and also between the two hind limbs, there is 
stretched an elastic skin or membrane, which the bat uses for flight and for its wonderful sense of touch.

As the bat flies at night it is said to possess poor eyesight; but when one sense is defective another is often very strongly developed. So the bat has a wonderful sense of touch. And this sense-touch has its seat in the flying menbrane, in the skin of the ears, which are often large, and in some bats also on the nose and lips.

If a bat has poor eyesight, how does it capture its winged prey, for it flies fast and without the slightest noise, and its swerves are remarkably swift and sudden?

One evening a bat flew into the writer's room, and he was amazed at the rapidity of its flight and sudden swerves round the room to avoid any collision with the things in the room.

How did it avoid knocking against the walls and furniture of the room, of which it had no previous experience?

Is its sense of touch so remarkable that it can feel when it approaches an object, or does the bat possess some other sense of which we know little or nothing?

There is much to be learnt about a bat.

Bats are particularly useful to agriculturists, and on no account should they be destroyed.

They prineipally devour night-flying moths 
and spiders. The caterpillars of many of the species that they destroy are very injurious to agriculture and forestry.

\section{Gnawing Animals.}

All the gnawing animals have four long teeth, called incisor teeth, the crowns of which are continually being worn down; but in order that they should not be worn away altogether, a growth corresponding to the loss takes place at the root end.

Gnawing wears down these teeth less in front than behind. Their crowns therefore are always sharp like a chisel edge.

The large incisor teeth are used for gnawing, in which process the lower jaw is moved backwards and forwards.

Hares, rabbits, rats, and mice are all gnawing animals.

Hares and rabbits are so well-known to you that there is no need to give any details about their life history.

The Mouse Family. The larger members of the mouse family are ealled rats, and are often confused with the vole family, but they are really very different in appearance.

The mouse family includes the black, and brown rats, the common mouse, the long-tailed field mouse, the harvest and corn mouse. 
All the members of the mouse family have slender bodies, long legs, pointed heads, with ears that are very visible, and with tails naked, and in most cases equal in length to the body.

Now mark the difference between this description of the mouse family and the following description of the vole family. The voles include bank voles, water rat or water vole, and shorttailed field mouse. The voles have plump and short bodies, thick head and arched forehead, with blunt snout and ears quite hidden in the fur, and a short hairy tail.

Perhaps there are no animals so destructive to the farmer as rats and mice, and no animals so difficult to get rid of. It is impossible to estimate the loss that the agriculturalist suffers through rats and mice. If the sum total could be worked out it would be startlingly large.

The smaller black rat was the original rat in this country, but the stronger and larger brown rat has almost completely exterminated the old English black rat.

The brown rat was brought to this country in ships from abroad, probably from India or Russia.

House Mouse.-A pretty little creature is the house mouse, but a great nuisance when it gets lodgment in a dwelling-house or out-building.

The long-tailed field mouse is found in woods. 
plantations, gardens, and fields. It is very destructive.

The harvest mouse builds a beautiful spherical nest with blades of grass and corn, and suspends it amidst the living eorn plants.

It is a pretty. sight to see the little ereature elimbing among the high stalks of grass and corn, holding fast, not only by its feet, but by its tail.

It eats a quantity of grain, but also a quantity of injurious insects, therefore spare its life. It is so pretty, and its nest such a work of art. The country would not be nearly so interesting if all these wild things were got rid of.

The Vole Family. The large voles are popularly called rats, the smaller ones mice. In some respeets they resemble the true rats and mice, but they are really very different, as you have just read. They include the bank voles, the water rat or water vole, and the short-tailed field mouse or field vole.

You have often secn the water rat or water vole. A splash in the water, and probably a water vole swims away.

It digs many branched passages in the banks of rivers, brooks, ditches, and canals, and sometimes to such an extent does it riddle them that they are completely destroyed.

It does great damage in grass fields and corm 
fields, and eats grain, potatoes, turnips, and carrots, and stores a large quantity of food in its hiding-place.

It also destroys roots of corn and grasses, and occasionally devours young chickens, ducks, and the eggs of ducks and geese.

It is said to destroy a certain amount of injurious insects, but the good it does is said to be far outbalanced by the harm.

The field vole, or short-tailed field mouse, lives in pastures, preferring those which are low-lying and damp. Large numbers are found together, and they make deep burrows in the soil, each pair having a special nest to itself, and bringing forth three, four, or even more litters per year, with four to ten young in each litter. Its favourite food consists of roots, young shoots of grass, and the tender bark of shrubs; but nothing of a vegetable nature comes amiss. Specially destructive is it to permanent pasture.

If you wish to keep your rats, mice, and voles, which cause so serious a loss to agriculturists, from increasing beyond reasonable limits, don't exterminate the weasel, stoat, polecat, hedgehog, owl, buzzard, kestrel hawk, and the smaller sea gulls, for these are their natural enemies. 


\section{BIRDS.}

Leave for the moment out of your consideration the great good that the birds do in keeping down insects, and thus saving the crops from partial destruction. Leave that out, and think only of what a difference birds make to the brightness and interest of the country. Their beautiful song, their marvellous flight, their matchless colour-how it charms and soothes, if you have eyes that can see and hearts that can love the beautiful.

The writer has been in foreign countries-the skies were blue, the flowers here and there beautiful; but there was a something wanting, something missing-a void. And that something was the song and movement of birds.

If a foreigner or a visitor from one of our colonies comes to this country, it is not the endless morement and rhythmical order of huge London, nor the smoke and intellectual bustle of the manufacturing centres that strikes him with wonder. It is not this that he takes away in his heart to remember, but the green grass, flowering lanes, and singing birds of England's country.

London and the manufacturing centres he can 
find in miniature, it may be, in his own land; but England's country he can find nowhere else.

That stands alone, with no rival amidst the beauties and wonders of the world.

On a fine, still, spring day, when the mood is on you, lie on your back upon the grass, and

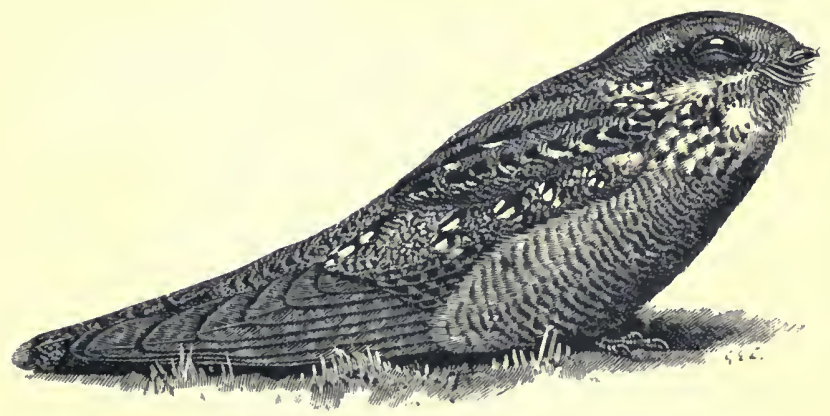

THE NIGHT JAR.

for" a few moments listen to and think of the call notes and songs of the birds. And the air will seem full of soothing musical sounds near at hand and far away on the horizon. You can hardly feel dull ther. The country will not feel lonely then, with so much of cheering, moving life all around you-the life of the bird pouring itself out in song without stint or measure, and telling us to feel ashamed if we, too, do not joy in living.

The song, colour. and movement of birds has stirred hope in many a weary, broken human heart. 
Have you ever noticed the colouring of birds in the spring, when they are at their brightest? If you have not, well then just notice it. It will reward you for your trouble.

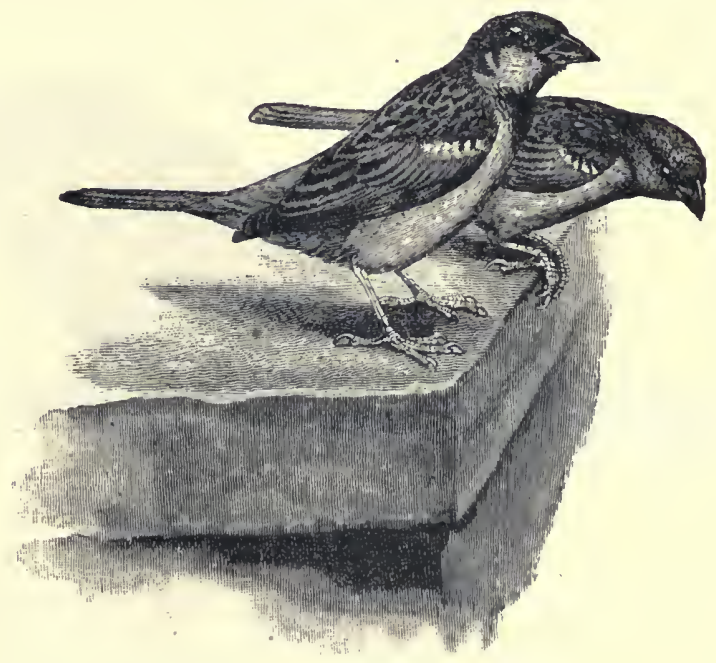

HOUSE SPARROWS.

The colour of a flower is beautiful, but the colour of a bird seems to transcend it, probably beeause life pulses stronger through the body of a bird than it does through the shape of a flower.

'The sparkling gemson a three-year-old starling's back; the red brown tinge of the hedge sparrow; the red of a robin's breast; the bright yellow of 
a hammer's body; the black shining glitter of a blackbird; how startlingly living is the colour!

Notice, in the Spring, how fresh and beautiful are the different shades of brown on the back of the despised house sparrow, as he hops on the road picking up his bit of food. Observe with what delicacy they shade into each other. The eye and the mind are not offended by colour clashing with colour in the tints of wild flowers and the markings of the free bird.

Once the writer was living in one of the London suburbs, his study window overlooked a small back garden, and in order to relieve the monotony of his constant writing, he erected a Hat board about 5 feet high, supported by two uprights. These uprights were placed well under the board, so that no cat could crawl up the upright and on to the board. And on the board he placed sciraps from the table, water, and hung down bones and pieces of suet for the tits. All through a very hard winter, all sorts of hirds collected on and around that board. They got quite tame, and as he looked up from his writing he had every opportunity of observing their different ways and endless shades of colouring.

They lifted his mind. and he thinks they helped his writing to be more life-like, and his sympathies to be wider. 


\section{The Formation and Flight of Birds.}

The great laws of God work on, and they slowly but surely adapt all things to fit into their appointed places, the animals to walk the earth, the insects to buzz through the air, the birds to soar, fly, and swim.

Birds are warm-blooded and breathe by lungs, and in order that they may fly to the best advantage and escape danger, they are covered with feathers and have no teeth, but a horny beak. Their bones are hollow and filled with air, and when they begin to fly their lungs force the air into these hollow bones, which enables them to rise into the air with greater ease.

The body is firm, especially the hinder part which is quite unmoveable, but in order that the bird may obtain an all round vision, so necessary to capture its insect food and to see the approach of danger, the neck can be turned quickly in many directions.

The body, as you know, is covered with thick long feathers, underneath which and hidden from view is short soft down. 'The feet are adapted for quick, delicate, firm perching.

A bird's wings are really forelegs modified into wings, and if the wing be dissected, the parts found in an animal's foreleg can be recognised. 
A bird by puffing out its feathers can protect itself against cold and wet. In wet weather you have often seen a bird's real outline of figure disappearing in a round ball of puffed out feathers.

Then just think how effective for a bird's safety is its method of picking up and digesting its food. Down it comes, picks up its worm or bit of food, gulps it into its crop, flies quickly away to a place of safety, and then digests it at leisure.

As the horse has been given speed, the cow horns as a means of preserving their lives, so the bird has been given wings, beak, and crop, as the best method of preserving its life.

Flight.-How wonderful is the flight of birds! Pages alone could be written on this.

Have you ever considered that there are no two things quite alike, anywhere around you. No two human faces are quite alike; no two sheep in a fold that a shepherd cannot tell apart; no two hounds in a pack that the huntsman ever mistakes one for the other; no two peas in a porl but some shight difference can he found between them. And so each separate species of bird possesses its own peculiar Hight, which differ's from the Hight of another species.

A careful observer can distinguish every speeies of bird by its own particular Hight. A 
chaffinch flies in an up and down motion. A starling flies quite straight. A swift and swallow

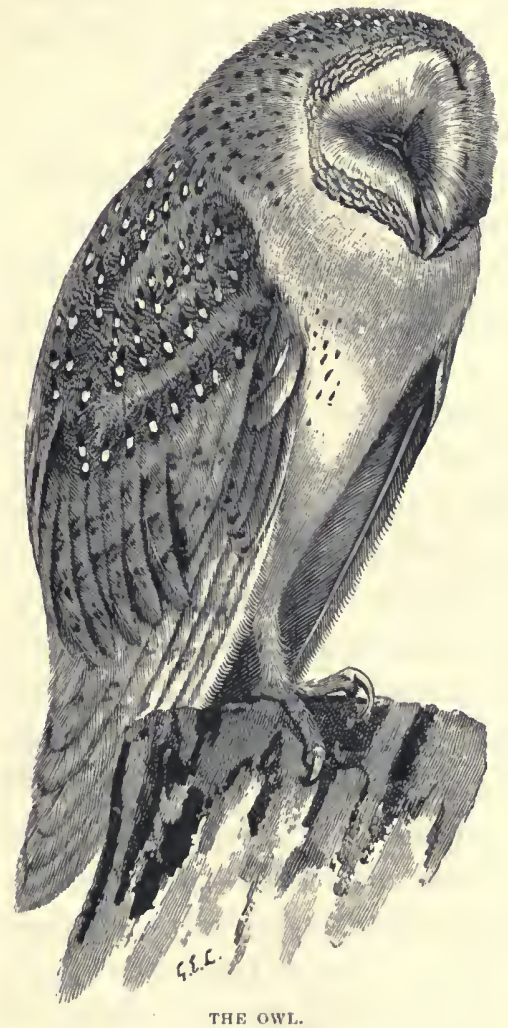

THE OWL. glide and curve.

A peewit swoops and jerks. A kestrel hawk hovers and drops suddenly. An owl flies and drops of a night on a mouse from a great height without the slightest noise. And so on throughout the list of birds.

'The air is full of currents and cross currents, up and down currents, currents differing in their degrees of heat and cold, and differing alsoin their

degree of velocity or speed.

The birds seem instinctively to know how best to save their powers of flight by taking advantage of these various air currents. 
Wateh a swift high up sailing about in a clear blue sky. With hardly a movement of wing, the little black-bodied bird will glide down one eurrent that gives the neeessary impulse to aseend by another; now with a flutter of wing elimbing to a greater height, now with contracted wing deseending to a lower height, now with outstretched and motionless wings, turning to right, turning to left to eateh on its side the wind that gives the impulse that carries it forward like the sails of a ship spread out to catch the wind that blows on its beam.

One of the most beautiful sights the writer has ever seen was a huge flock of starlings and plovers high up in the air, each species keeping together in dense masses, flying backwards and forwards, ascending and descending, but slowly getting further and further away till they disappeared as two tiny specks in the quiet glow of an autunn sun.

Another time he noticed a dense mass of peewits flying, it seemed, for the pure pleasure of flying, and as the birds first turned their backs and then their lighter undersides to view, the sun reflected their different colours with lightning rapidity in bold relief against a black thunrler cloud.

And then that most wonderful Hight of all, the migration flight, when the birds in the fall of the 
year collect in batches from over their breeding areas, and these little batches join other batches

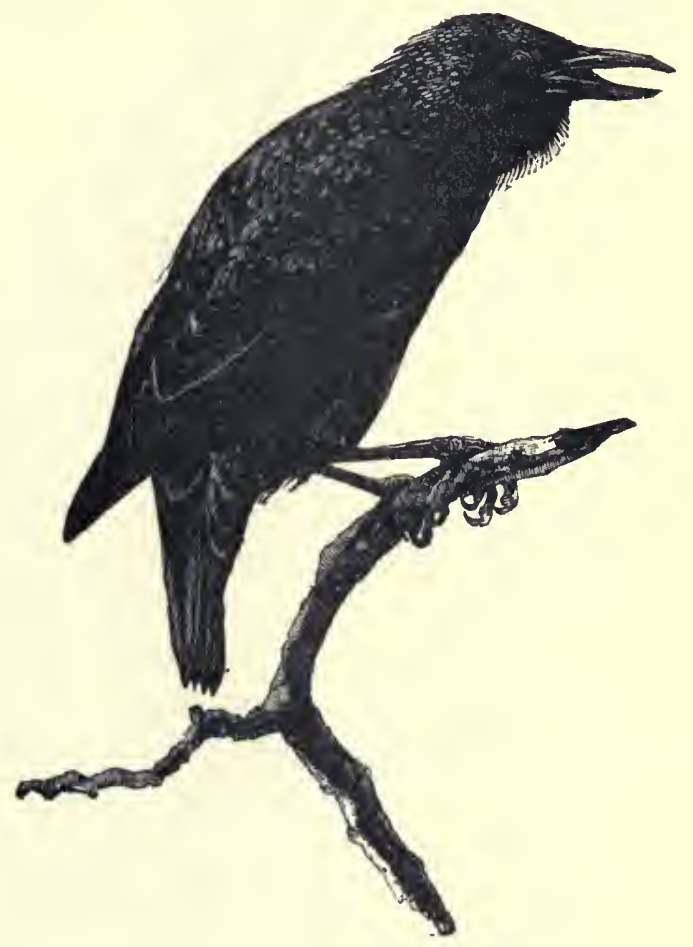

THE STARLING.

till they collect in huge flocks that no man can number, and fly by certain fixed and well-known routes of coast-lines, mountain chains, and rivers, over seas to the land where the sun shines, and where their insect food can be found in abundance. 
THE FORMATION AND FLIGHT OF BIRDS. 205

And next year with the same unfailing regularity they collect and return to the land of their birth, to mate, build nests, and rear young.

\section{Birds do Good.}

Almost all English birds do more good than harm. Some species, of course, do more good than

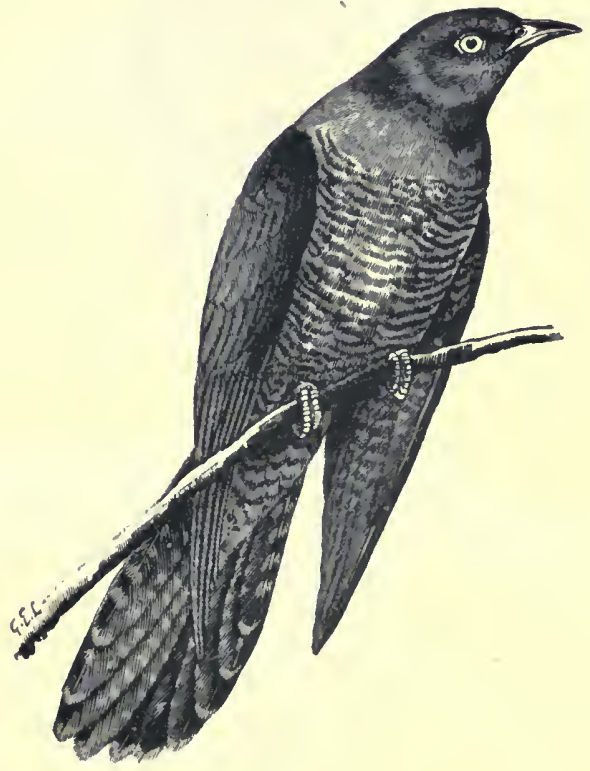

THE CUCKON.

others, and if any species that under ordinary conditions do more good than harm be allowed to multiply in too large numbers they will probably do more harm than good. 
The following birds are always beneficial: swallows, house martins, sand or bank martins, swifts, owls, cuckoos, goat sucker, night jar, tree creeper, nuthatch, wrens, larks; all sharp-beaked singing birds, namely, nightingale, redstart, robin, grasshopper-warbler, linnet, wagtail, golderest; all the tits, and peewits.

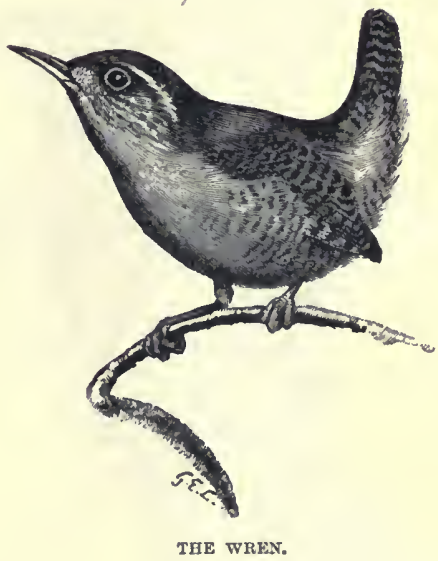

The following are usually beneficial, but under exceptional circumstances may do some harm: thrushes, starlings, chaffinches, and bullfinches.

The kestrel hawk and buzzard being destroyers of field voles are in the main useful.

The magpie and jay, birds that are closely related to the crow, are said to be more harmful than useful, but it should be remembered that, although they eat the eggs and young of use- 
ful singing birds, young dueklings, ehickens, and young partridges and pheasants, they also eat

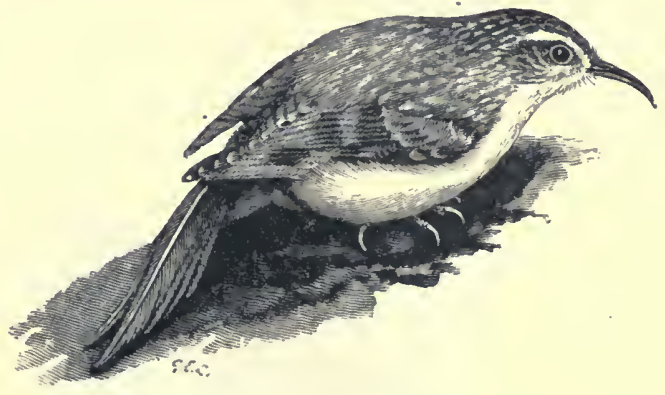

THE TREE CREEPER.

large quantities of eockehafers, wire-worms, and other insects; and now and then they destroy field voles.

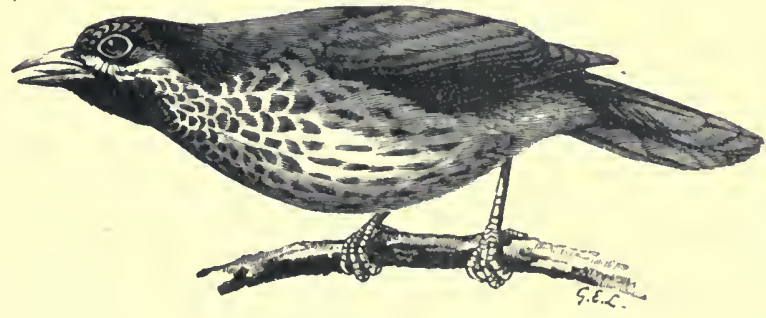

THE THRUSH.

It must not be forgotten that birds that at times do a certain amount of harm by eating fruit from the trees, and seeds out of the ground, and grain out of the ear, invariably feed their 
young with caterpillars and other insects. And a nest of young birds will eat an enormous quantity before-they are able to take care of themselves.

Many skilful experiments have been made on the stomachs of birds of prey to find out what

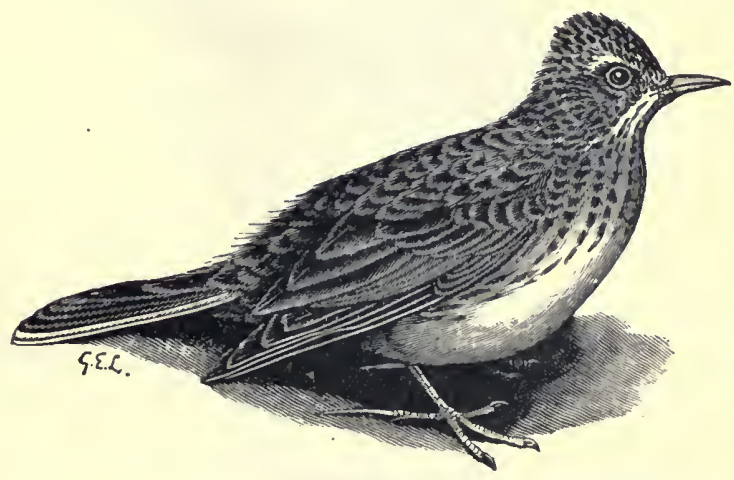

THE SKY-LARK.

they contained, and in almost every case it was found that they contained the remains of more pests, than remains of game birds or useful birds.

Not only do birds destroy pests, but many species consume a large quantity of the seeds of weeds, and especially during the winter. Whenever you see a number of birds over a bare fallow, do not disturb them, and, above all, do not kill any of them. Let them feed in peace, for they are making that patch of ground, and it, 
may be, the surrounding country, better able to support a paying crop.

The preservation of the useful birds is a question that concerns both landlord and tenant.

Every farmer, if he knows his business, ought to be the protector of the birds, and see that the

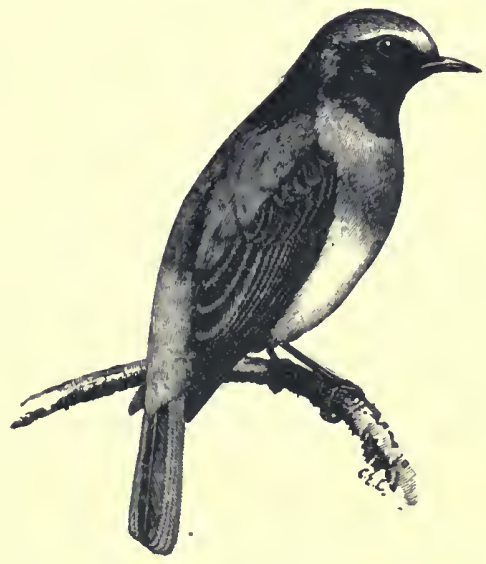

THE REDSTART.

nests on his holding are not destroyed; and every landlord who desires success to British agrieulture ought to give his gamekeeper a list of useful birds, with strict orders that their nests are to be preserved.

But what direetly concerns the landlord and farmer concerns indireetly the cottager and the nation. If the acre does not produce of its best 
on the lowest outlay, the nation in the long run is the loser.

Therefore the preservation of our useful birds is a national question, and, being a national question, every man, woman, and child who cares for the good of the country ought to protect and encourage them by every means in his power.

\section{INSECTS.}

You will now read something about insects.

The different varieties of insects are so numerous, and we have found out so much about them, that in a short chapter we can only deal with them in a very general and superficial manner.

If you wish to learn more about them you must consult books that deal with them in fuller detail.

It may be stated that the bodies of insects are divided into three principal sections or parts : the Head, the Thorax, the Abdomen.

The Head section contains the eyes, which are made up of a large number of smaller eyesin some cases up to ten thousand. Many insects have a few smaller eyes placed on the top of the head. 
'The feelers or antennae alct as organs of touch, and perhaps serve some other useful purpose.

Insects that live by tearing and chewing their food, have short sharp-edged jaws, while insects that take in food by sucking up blood and the juice of plants, have their jaws much lengthened, so as to be able to lick, suck, and pierce.

'The Thorax, or middle section, contains the legs, and sometimes a pair of wings in addition.

The Abdomen, or hind section, possesses no limbs, but digests the food and lays the eggs.

So you see that the three principal parts or sections of an insect do their own particular work and are dependent one on the other.

'The Head section sees, feels, and takes in foor.

The Thorax section moves the insect by walking or flying.

The Abdominal section takes in and digests the food, lays the eggs, and, in some cases, uses a sting as a weapon of defence.

An insect does not draw in air through one mouth, nor has it lungs. But inside the insect can be seen a great number of the tiniest and most delicate branching tubes that carry air to all parts of the body. The outer air gains admission to these tubes through small apertures or mouths situated in the skin. These little mouths or inlets are placed at regular distances 
along each side of the insect's back, and are usually nine on each side.

These tiny mouths guard admirably the entrance to the little branching tubes. They can prevent any foul air getting in, and also can keep a quantity of good air in the tubes.

Both butterflies and moths have antennæ or horns.

In the case of the butterflies, these horns end in a knob, like a drumstick; whereas the horns of a moth have no knob at their ends.

Butterflies, when they settle, raise their wings, so that they meet back to back and show their dingy under-sides. The attitude exposes the whole of their body.

Moths when at rest keep their wings spread out so as to cover and conceal the whole of their bodies.

Butterflies usually fly by day, while moths fly at twilight or at night.

'The short wings of beetles consist of a pair of hard wing covers, which overlap and protect the folded hind wings.

Beetles have biting jaws. All beetles pass through the changes of egg:-Larvæ (grub or caterpillar), pupa (chrysalis), imago (perfect insect, namely, beetle).

The larvæ of the beetle are usually fleshy grubs, their mouths being furnished with biting jaws. 
The butterflies and moths possess four wings, which are often covered with scales of various and beautiful colours.

The mouths of butterflies, instead of being adapted for biting, like beetles, are adapted to sucking. In consequence, the upper lip and jaws are small, while the lower jaws are formed into a long tube proboscis, so that with it they can reach the nectal, that may be situated at some distance from the top of the flower, on which they alight.

When this long tube or proboscis is not in use it is coiled up like a watch spring, and concealed beneath the head.

The females of some insects possess a long ovipositor, attached to the abdomen. 'They use this ovipositor as a borer and for laying their eggs.

In some insects, however-bees, wasps, hornets -the ovipositor is developed into a sting.

The butterflies and most moths pass through the fourfold stage. Egg; larve or caterpillar; pupa or chrysalis ; imago or perfect insect, namely, butterfly or moth.

Most caterpillars are naked; a few are hairy.

Many of the buttertlies, as you have observed, are very beautiful, and they do little or no harm themselves; but their larvæ, or caterpillar forms, are very destructive to vegetation. 
On the other hand, many of the beetles do more harm than their grubs; especially is this the case with the turnip beetle.

\section{Transformation or Changes of Insects.}

If one thing is more wonderful than another in this wonderful and beautiful world, we might be inclined to say that the change or transformation of insects is the most wonderful of all.

Supposing we knew nothing about these changes of insects and some one brought to us a dowdy, erawling caterpillar, or an insignificantlooking grub, and a lively graceful butterfly, or glittering hard covered beetle, and said, "That caterpillar and grub will one day change into a butterfly and beetle of like appearance." Should we believe it?

We should, more than likely, scoff, and say that the thing was impossible.

But every summer this transformation is going on in myriads and myriads of insect lives. In the trees, under bushes, in crevices of rocks, in the open fields, amongst the crops, and in the bodies of animals, the transformation scene is going on without ceasing. As soon as the sun with sufficient warmth touches the sleeping hidden insect life it responds to the magic command by filling air and soil with countless forms of living beaty and grace. 
A butterfly or beetle lays its eggs; in due time from these eggs a caterpillar or grub, with a ferocious appetite, crawls forth, living for a time, to change into a chrysalis, which in its turn changes into the perfect insect. And so the transformation goes on. Perfect insect, egg, larva, pupa, round to imago, or perfect insect again.

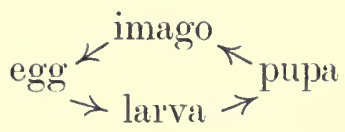

Small wonder that the old naturalists, not knowing as much as we do, thought that a complete transformation of one form of life into another form of life took place, a transformation as startling as though a serpent changed into a bird.

But our microscope, and hard-working students of science, have taught us very differently now. These transformations are not breaks, but so many changes, or seeming pauses, in the development of one and the selfsame insect.

An insect life is generally divisible into four well-marked stages, and the change from one into the other appears to be quite abrupt. But in reality it is not so.

The whole alteration fiom the egg to the larva, to the pupa, and then to the imago, or perfect insect, takes place not suddenly but very gradually. 
The changes in growth are going on unseen, working according to fixed laws, working on to the moment when the transformation is revealed to our eyes.

\section{Life History of Insects.}

In the egg, under the microscope, the changes and growths can be seen till the caterpillar crawls forth. The caterpillar almost directly it is hatched begins eating as hard as it can eat, and an enormous and unsatisfied appetite it seems to possess. Its first meal often consists of its discarded egg shell. It naturally increases in size, and the skin has to stretch to allow for its growth. Then a time comes when the skin can stretch no more, and so it cracks, and the caterpillar or larva crawls forth clad in a bright new coat.

After this moult, as it is called, the caterpillar is soft and languid. It soon recover's itself, however, and begins to eat with a bigger appetite than ever. These moults generally occur about three times, sometimes oftener.

The first moult usually takes place about twelve days after hatching, a second a week after that, the third six to eight days later still.

After each moult the insect consumes larger 
quantities of food till the last coat is cast off. These coats, as you can well understand, are cast off to allow the insect to grow. When it ceases growing it throws off no more coats, but soon enters into the next stage of existence-the chrysalis, or resting condition, called the pupa.

As long as the insect remains in the chrysalis condition, it tastes no food and remains quite quiet, only when touched showing the slightest movement.

Some insects remain in this resting condition for several months; but many, if not most, remain so for a week or ten days only.

In every kind insect the length of the chrysalised condition depends on the weather:

If a butterfly cater-

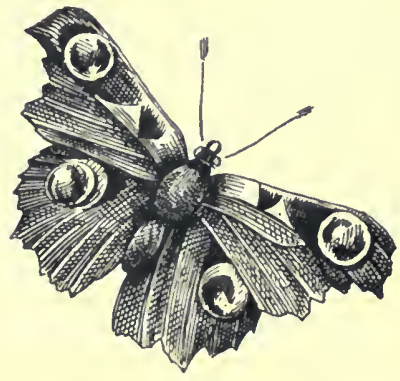

PEACOCK BUTTERFLY.

pillar turns into the pupa condition during the summer months, the perfect insect may emerge in eight or ten days; but if the chrysalis condition is reached at the approach of winter, the change may be delayed till the warmth of the following spring sun comes round.

When the time approathes for the perfect 
insect or imago to emerge from the sleeping chrysalis, the pupa coat is cast off, and the insect comes forth perfect in all its parts.

Very naturally after all these exertions the insect rests awhile before taking to flight. The wings of butterflies and moths at first are somewhat drooping and difficult to spread, and the body is soft and moist.

After a rest and exposure to the sun the insect gains strength, pulls itself together, and its wings enlarge and expand; and then away it Hies, happy in its higher career, glad of its freedom.

But it has not long to live. The female imago lays the eggs and then, soon afterwards, dies, and so the round of its existence is complete.

From an egg, through the steps of caterpillar and chrysalis, the perfect insect has come.

The length of the life of a larva depeuds on the quantity and quality of the food that it can obtain.

The larval life of the bee is less than a week, because the grub, directly it is hatched, finds food all around it-a plentiful supply of honey and pollen.

The blow fly, hatched out in meat, remains a larva from eight to ten days.

The caterpillars that feed on leaves have to work harder for their food, and as it is of a less 
nourishing character their larvae oceupy six to eight weeks between the egg and pupa.

Wire worms and cockchafer grubs, which live in the soil and feed on roots, have unfortunately a larval life extending from one to five years.

There seems to be no part of plants and trees that is free from insect attack.

Wèevils destroy seeds.

The turnip beetle pounces upon the young seed leaves directly they appear above ground.

The saw fly larvae give to leaves a scorched appearance.

Some insects tunnel into the tissues of leaves; other insects cause the little gall swellings which at certain years appear all over the leaf.

The caterpillars of the cabbage butterfly riddle leaves with holes, and cockehafers devour leaves wholesale.

Blossoms are destroyed by beetles and aphides or gieen fly.

Stems and woody trunks are attacked by the bark beetles, goat moth, caterpillars, and other borer's.

The wire worm is the chief' enemy to the roots of crops, but it.has many helpers.

Some insects confine their attacks to special groups of plants, as the turnip fly to the turnip group, namely, the cruciferous crops. 
Others are general feeders, as the wire worms and leather jacket (larvae of cockchafer).

\section{Insects Harmful to Live Stock.}

Let us now read about some of the best known insects that are harmful to the live stock of a farm.

Gnats. You know these little stinging buzzing insects, and so do your live stock.

It is a long slender insect, with very long thin legs. The male does not sting, but sucks up water and juices of plants.

The female is our enemy, because she is not satisfied with sucking up water and juices of plants, but she sucks up blood as well, and it is the piercing of the skin with her long proboscis to get at the blood that causes the pain.

The female lays from 250 to 300 eggs on any object floating about in staguant water (pools, ditches, etc.). They breed with special rapidity in hot summers, and on badly-drained soils. Therefore the best method of getting rid of gnats, as well as mosquitoes, is to get rid of all stagnant water and to keep the land welldrained.

Gad Flies. These are medium sized flies, with thick bodies, large heads, and strong legs. The male fly lives on plant juices, but the female of 
the larger kind attacks horses and cattle, and so fierce is its bite to get at the blood, that if the attacked animal stands after it is bitten, drops of blood may often be seen on the ground where it stands.

The Forest Fly is about onethird of an inch long. It is a brown, broad fly, with two broad

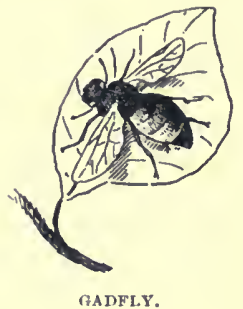
stumpy wings. It seldom flies. In summer and autumn it sucks the blood of horses, especially about the stomach and flanks, and it causes great irritation by moving all over the body.

When it settles it sticks very tight, and can easily be killed with the hand.

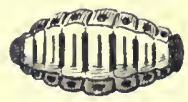

Warble or Bot Fly. This fly is one of the greatest pests that our cattle suffer from. It is on the wing during the summer (June to September), and when the cattle hear it they get very

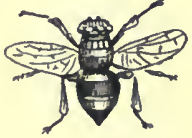

WARBLE FLY AND MAGGQT.

(Estruy Bovis.) restless, gallop about like mad, with tail in the air. They will take any risks, jump down from heights, and if the pasture is on the edge of a wood it will take a very strong fence to keep them out. They seem to think that by rushing at break-neck speed through a wood they may get rid of the fly. 
The poor beasts rush about trying every means to escape the attention of their enemy, which they seem to know is desirous of laying its egg on their hide.

If the fly is suecessful in laying its eggs on the cattle,-young eattle for choice,--when the maggot hatches out, it tunnels inside the skin, and in course of time sets up inflammation.

The maggot feeding and living inside the cattle, causes a kind of tumour or "warble," which appears in the following spring as large as a pigeon's egg.

The maggot then crawls out of the poor beast, and lets itself fall to the ground, when it turns into a black pupa or chrysalis. Some three weeks later the fly appears, and then seeks out some unfortunate animal on which to lay its eggs. And so the round goes on again.

If an animal has many warbles they very much damage its health, and interfere considerably with the flow of milk.

Starlings do good service by settling on the backs of the cattle, and with their beaks pecking out the maggots.

Starlings, rooks, and wagtails, also devour the maggot that has dropped from the cattle for the purpose of becoming a chrysalis.

Of course these holes made by the maggot of the warble fly in the skin lessen the value of the hide. 
A farmer told the writer that by mopping over his cattle once a fortnight, when the fly was about, with a certain prepared smear his eattle were not attacked.

If you smear over the hole, which is about the size of a pin hole, that the maggot has made to enter the body, with any kind of grease, it prevents the air getting to the maggot, and so kills it; but mercurial ointment is the best remedy, for it not only kills the maggot, but dries it up.

There are three principal diseases that attack sheep, and they are all three the work of an insect or parasite.

Foot Rot, which drives the animal lane, is caused by a parasite that lives in the feet. The remedy is to eut away the diseased part. and then dress it with a lotion.

Scab. A terrible disease, which is eaused by an invisible parasite living under the skin. The remedy is to cut away the wool from the scabby part and dip the infected animal several times in a poisonous preparation called a Dip.

The Fly. In the warm and humid weather a fly lays its eggs in the wool of a sheep. maggots hatch out from the eggs and then begin eating their way into the body of the animal. If the work of the parasite is not checked by shearing, washing. and smearing, the animal 
attacked will soon lose condition, and in some cases will die.

\section{Harmful to Crops.}

Wire Worms.-Of all pests to our crops the wire worm is perhaps the worst ; it eats all the underground parts of potatoes and turnips, as well as the underground stem parts of grain plants. It also does much damage in meadow and grassland; in fact there is nothing that seems to come amiss to it. You must all have noticed, in the midst of a flourishing erop of grain or roots, large bare patches, sometimes acres in extent. That clearance has most probably been the work of the wire worm.

At first the greenlooking grain crop looks healthy enough, then a slight tinge of yellow comes over it, till at last it disappears. The wire worm, underground, has gnawed through the roots. 
Click Beetle.-The wire worm is the caterpillar of the cliek beetle or skip jack. This . beetle is a longish insect, very strongly protected about the head. It is so made that if it should fall on its back, which amongst the furrows it
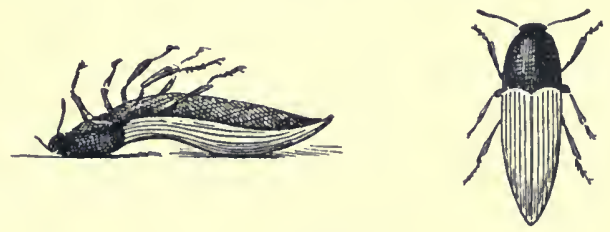

CL.ICK BEETLES.

must often do, it ean spring in the air and alight right side up.

The wire worm is more destruetive in dry soil than in wet.

The worst of the wire worm is that it requires four or five years for its development, so that the same field may be infested with it all the year round, and year after year. The greatest damage is done in spring and winter.

The best remedy - and perhaps the only remedy -is constant ploughing of the infested fields, so that the rooks, starlings, peewits, and wagtails ean get at them. Especially do your utmost to preserve the peewits. If the farmer and gardener has a real friend, it is the peewit. It is madness to thin these birds by killing them or by taking their eggs. Do everything you can 
to encourage them. Whenever you see the - peewits at work rejoice, for you know for certain that this bird at work is saving you many pounds of money. If the peewits were plentiful, and had a fair chance, you would probably not have much bother with the wire worms.

It is said that a plot of waste potatoes will draw the wire worm from the straw crop.

Surface Caterpillars are stout caterpillars $1 \frac{1}{2}$ to 2 inches in length, with a shining transparent external skin. The best known is the turnip moth. The worst of these caterpillars is that they attack the plant both underground and above ground. On clear days they bore into the juicy underground parts of turnips and carrots, and, during the night and cloudy days, they will come above ground and attack the leaves and stems of young plants.

The turnip moth can be seen flying about from the middle of May right into the autumn. They lay their eggs singly in the soil close to the plant root, so that, when the caterpillar hatches out, it has a store of food ready to hand.

The caterpillars in autumn do most damage to the winter crop, wandering about from plant to plant. They gnaw through the main roots, which quickly kills the plant attacked, and then they pass on to the next.

Warm soils are most troubled with these sur- 
face caterpillars, and, therefore, horse dung must not be placed on lands where they are known to exist. Ploughing and birds are again the best remedy.

Turnip Flea Beetle, or Turnip Fly.-Perhaps you have been asking a farmer: "Well, how about the roots?" and he may answer: "Oh, I have got the fly." Strictly speaking, he means the turnip beetle.

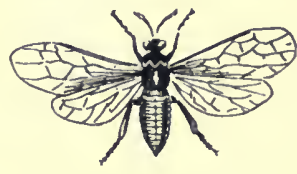

TUENIP BAW FLY.

The turnip beetle is from one-tenth to oneeighth of an inch long, egg-shaped, black, with streaks of a sulphur-yellow colour on the wing covers. The caterpillar or larva is one-fifth of an inch long, yellowish-white in colour, with a dark brown head.

The beetle begins its attack in the spring, and in all cases the young plants are devoured. Seed leaves and terminal buds are eaten; especially is the damage great in dry weather, because in dry weather the plant cannot grow fast enough to push quickly enough past the young leaf stage. As soon as the young leaves appear they are devoured; and, in consequence, the health of the whole plant is damaged.

The grub of the beetle is not so destructive as the beetle itself, because the grub generally attacks the older leaves. 
The female beetle lays her eggs singly on the leaves and generally on their underneath sides. The larva when hatched bores into the leaves and digs a passage, which at first is small, but gets gradually larger. In fine weather, the larva, in a week, has grown to its full size. It then pierces the skin covering of the leaf, and falls to the ground, and becomes a pupa. If the weather is dry this may go on several times in the year.

The remedy for this pest is first and foremost to keep the land free from the weeds which attract the beetles, namely, Charlock, shepherd purse, yellow rocket, treacle mustard; also good preparation of the soil, suitable manuring and drill culture, since these conditions bring about a rapid growth of the plants, and so push it rapidly past the young leaf stage when it is specially attractive to the beetle.

A dressing of gas lime is sometimes very beneficial.

Cockchafer._The cockchafer beetles appear usually about May. In the evening they leave the soil and seek the neighbouring trees. They devour the leaves, and specially the buds of the oak, horsechesnut, beech, poplar, willow, cherry, and other forest and fruit trees, but spare the lime and generally the morel cherry.

In some regions where the insect is abundant, 
every three or four years is called a cockchafer year, and then the beetles appear in millions, while scarcely one can be found during the intermediate year.

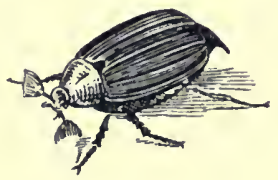

COCKCHAFER.

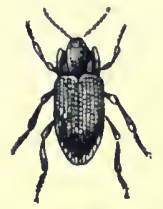

GROUND BEETLE.

When they are numerous they are a perfect scourge. The female lays about 40 eggs; the grubs devour grass and clover roots, and the roots of grain plants, peas, beans, cabbage, and potatoes, and in gardens the roots of many vegetables, and in particular the underground parts of strawberry plants

The natural enemies of the cockchafer are moles, shrews, bats, crows, starlings, owls, and the large species of ground beetle.

Daddy Long Legs, or Crane Fly.-The daddy long legs which you all know by sight is a very long-legged gnat, without sting, which lives on the juices of plants. These long-legged, unsightly looking insects, in some summers fly about in swarms, generally about the same field in which they were hatched in the spring. They lay their eggs in the fields, and the eggs are often blown about for long distances by the wind. Each time 
the fly settles she lays two or three black looking

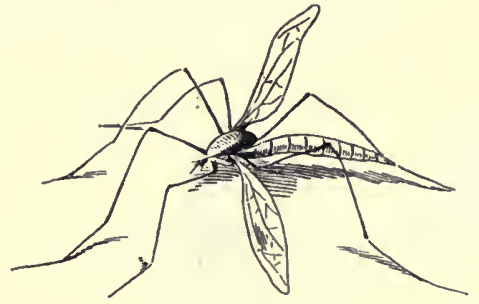

DADDY LONG LEGS. eggs bent like a sickle, and repeats the process till all her eggs are laid, some 250 in number.

Those fields which have been previously grassland are most infested. From under the pieces of turf that are left in the fields they come out to attack the standing corn that is generally grown after grass or seeds. They devour the roots of grasses and corn, and do most damage in the spring and autumn.

These insects not only attack the roots, but in the day time, during dark, damp weather, they devour parts of the young leaves of the young corn plants.

In May the larva is ready to pass into the pupa stage. After a rest of fourteen to seventeen days the pupa works its way near the surface till the front part of the body sticks out of the soil. From it the fly then escapes. Its natural enemies are moles, shrews, wagtails, grasshoppers, warblers, rooks, and gulls.

The Aphides, or plant lice, commonly known as the green-fly, are also called the 
"smother fly." This is a most appropriate name, for in a bad year these pests. literally cover everything that they attack.

You must know the green fly well. It has long thin legs, with no power of springing.

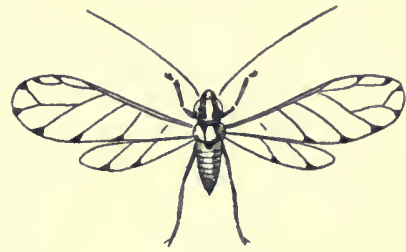

GREEN FLY.

Its proboscis is long and thin, and made for sucking. Some species have wings. Others have not.
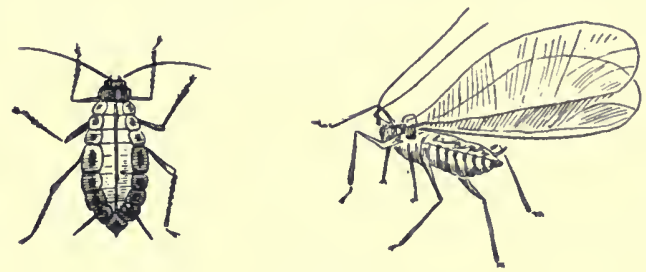

hop APHIs.

These aphides suck plant juices during the whole of their lives, and as they have enormous powers of reproduction they are very destructive.

They suck from stems and leaves the juices which would be used by the plant to build up the plant itself, and which would be used to form the flower and fruit. The young bore into the same part of the plant close alongside their parent, and at once begin to suck up plant juices; and these in their turn begin quickly to 
multiply. The parts of the plant thus attacked shrivel for want of nourishment.

When all the food in any particular part of a plant is exhausted, some of the insects fly away and start a fresh colony on another plant, and so the work of destruction goes on.

Fortunately for vegetation, these green flies have many enemies. Starlings, sparrows, warblers, lady birds, and the larvae of many flies, are particularly fond of then. Great numbers are often killed by the wind and rain.

It is only in very dry summers that they increase enormously, and then it is that they do so much mischief.

Not only do green flies do harm by drawing away the natural juices of the plant, but they form a sugary, sticky substance. This substance evaporating, leaves behind a shining, sticky, solid substance, which closes up the little mouths of the leaves through which the plant obtains its nourishment. This sticky substance sometimes drops on plants growing at the foot of the plant attacked, or is carried by the wind to other plants, and so great damage is caused.

The spores or seeds of certain fungi produce many plant diseases. These spores being blown by the wind often adhere to the sticky substance made by the green fly, and will then begin to grow and multiply. 
It is therefore thought that these aphides may be the indirect cause of several plant fungi diseases, such as smut, etc.

In eertain summers the writer has seen heavy streams of this sticky substance fall from the trees attacked.

Club Roots. - You must often have heard the expression, "Oh! the roots are clubbed;" and if you pull up one of these clubbed roots you will find that the main root is much dwarfed, whilst the side roots are often swollen into spindle-shaped masses, so that the popular name for the disease, Finger and Toe, is very appropriate.

This disease is more often found on the heavier and richer soils. It is caused by a slimy fungus. The spores of this fungus by which it propagates its kind are very small.

From the soil, by means of the root hairs of the eruciferous plants, namely, turnips, cabbages, cauliflowers, rape-the spore finds its way into the plant, and very quickly produces slimy masses of fungi that live on the vital parts of the plant.

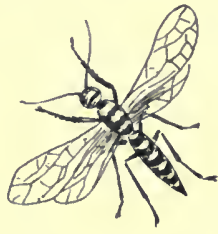

CORN SAW FLY.

The worst of the disease is, that it is difficult to get it out of the soil when once it becomes established. Perhaps the best remedy is to grow 
mangels when the rotation of turnips comes round again.

To avoid infection, whenever possible, the diseased crop should be burnt, on no account should it be left in the field or thrown upon the dung heap.

Dressing the land with lime has the effect of killing the spores in the soil.

Cheese Fly.-In parts of the country where cheeses are made, in farmhouses, this fly is a great plague. It is a very small fly, one-fifth of an inch long, slender, almost hairless, with dirty yellow legs and wings of glassy clearness.

If a hard cheese has not been well pressed, or if there is the slightest crack anywhere, these little insects will settle on the cheese and lay their eggs, which, turning into white maggots, soon begin their work of destruction.

When the time for the maggot to pass into the pupa, or resting-place, comes round, the insect will crawl out of the cheese and turn into a pupa on the walls, or on any straw close at hand.

Remedies: Great cleanliness in the cheeseripening room; constant whitewashing of the walls; gauze screens outside the window sufficiently fine to keep the fly out; keeping the cheese-ripening room dark; red-leading the joints between the boards, so that the fly cannot work upwards through the floor. 


\section{Some Useful Insects.}

Lady Birds. - Whatever you do, don't kill a lady bird. These beautiful insects -some black, spotted with red; others red, spotted with blackare most useful, because they feed chiefly on the aphides or green flies.

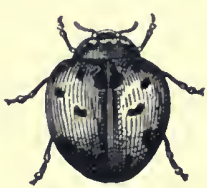

LADY BIRD.

The larvae are specially ravenous, and are longer than the beetle; they are found in large numbers amidst aphis colonies; their yellow eggs are laid in heaps.

When grasped, they emit from their abdomen a yellowish, unpleasant smelling fluid. No doubt this fluid is used as a weapon of defence against birds or other enemies, which, but for this unpleasant fluid, would exterminate them.

Ichneumon Fly. - A chapter alone could be devoted to describing these remarkable insects.

They lay their eggs, by means of a long ovipositor, in the bodies of larvae, principally

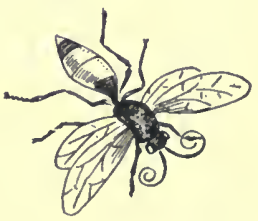

ICHNEUMON GROSSALING. in the bodies of caterpillars. Sometimes they lay their eggs on pupae, or even on the eggs of moths and butterflies. 
They always select an insect that is fat; that is, that has a good reserve of material.

The ichneumon fly has a long ovipositor; with this it pierces the body and lays its egg.

When the larva of the egg thus deposited hatches out in the caterpillar, it begins to eat of the food that it finds all around it-the body of the unfortunate caterpillar.

The insect that the ichneumon fly lays its eggs in is called the host, and the larva of the ichneumon fly that lives on the host is called a parasite, and a very appropriate name, for is not a parasite anything that lives on the work or lives of others?

So you see the larva of the ichneumon fly lives off the store of reserve fat and material so carefully stored up by the host for the needs of its own life.

Not only does the parasite feed on the body of its host, but, curiously enough, it breathes by means of the breathing apparatus of its host.

But here is the marvellous wistom of the whole proceeding.

If the larva of the parasite attacked any vital organ of the host, the host would die and its body would decay, and so the parasite would not have sufficient fresh food to support its life till the time when the parasite turns into the pupa condition.

Now, is not that really wonderful? - an insect 
so low down in the scale of life as the insect parasite, yet endowed with such remarkable powers as to leave the vital parts of the host till the last, and so make its eating and living keep equal steps with the eating and living of its host.

How did it reach this pitch of intelligence, reasoning, blind instinct-what shall we name it?

Did the hand of Nature or the hand of God select, and select without effort on the part of the insect, till the marvellous endowment of the ichneumon fly was reached? It may be so, but at present we don't know for certain.

Whole pages could be written on the thought that the life-history of the ichmeumon fly suggests to the mind.

The wretched host insect goes about its daily life with the dreadful parasite inside it, to all appearance not mich the worse.

Is the host aware that it is being eaten slowly away by the parasite inside it-that it is dying from slow consumption? We hope that it is not.

Some hosts will even turn into the pupa or chrysalis state, but never change from the pupa into the perfect insect.

Many an enthusiastic collector of butterflies has suffered keen disappointment on account of the work of the ichneumon fly.

The collector finds a pupa; he keeps it, 
awaiting anxiously the arrival of the perfect butterfly, but instead several little parasites appear, which are only the larvae of the ichneumon fly.

Although the ichneumon fly cannot directly prevent a spread of injurious insects, when these insects do appear the ichneumon fly appears in correspondingly large numbers, and so renders great service to agriculturalists.

Digging Wasps live in pairs, and in the summer, the female digs a hole in the earth in which she lays her eggs. At the same time she buries an insect, so that when her larvae hatch out, a plentiful supply of food is close at hand. Now here is a wonderful power possessed by these wasps. The female naturally does not wish the insect she has buried to decompose and thus be unfit food for her larvae. Therefore, before burying the insect she does not kill it outright, but by stinging it several times on the body she paralyses it, and thus reduces it to a condition of apparent death. She does this, so that when her larvae crawl out of the eggs, the insect meant for food, being not quite dead, is fresh and sweet.

Different species of these digging wasps bury caterpillars, spiders, weevils, flies, ctc.

Sexton or Burying Beetle.-Have you ever thought of the enormous number of deaths 
that are going on all around you-moles, shrews, field mice, rats, frogs, lizards, squirrels, dormice, bats, hedgehogs, to say nothing of birds that die, but how seldom we find their bodies. What becomes of them?

Of course a great many of the smaller animals die a violent death,

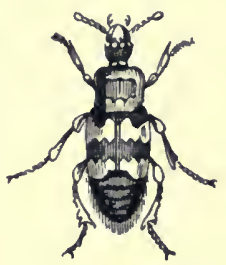

BURYING BEETLE. die between the jaws of their destroyers. An enormous number, however, die a natural death, worn out with the ever continuous struggle to live, done to death by accident, disease, or in fierce fight with rivals. What becomes of their bodies? Do they get a decent burial?

The sexton or burial beetle is the great gravedigger for these more lowly animals.

A mouse lies down to die. Two beetles or more, about an inch in length, with two bright orange bands on their hard wing-covers, come flying to the spot.

They settle on the dead mouse, and then quietly and carefully gather together their powerful wings, with which they really fly, and cover them over with their hard protective wingcovers.

The beetles are then armour-plated from stem to stern.

They are a tough morsel, but sometimes very 
hungry birds will swallow them whole, and hedgehogs will erunch them with their strong jaws before swallowing them.

The sexton beetle, like the lady bird, has a second line of defenee, namely, it can emit, when attacked, a very nasty fluid with a disgusting smell, which, if it gets on woollen clothes, will spoil them, and will cling to your fingers after two or three washings.

These beetles generally travel in pairs, and they settle on the dead mouse for two reasonsone to obtain an immediate supply of food for themselves, and the other in order that the female beetle may lay her eggs in the body of the mouse, so that when her grubs hatch out they ean have a quantity of food ready to hand.

It is stated that before the female lays her eggs in the dead mouse, they proceed to bury the mouse; cover it over, so that the store of food both for themselves and their grubs may last as long as possible.

It would take too long to enter into a detailed account of how this is done. But shortly, the body is dragged by several pairs of beetles to a suitable soft spot of ground in order that the grave may be dug with ease.

They then proceed to dig with their heads a tunnel beneath the mouse, earrying out the earth bit by bit, till the whole carcase sinks into the 
ground. They then throw over the mouse the earth they have excavated till the whole body is covered up.

When this is done the female beetle lays her eggs in the body of the buried mouse.

After the female beetle has laid her eggs and both beetles have had a good feed, the two parent beetles crawl out of the hole, and eover it up carefully so as to conceal the hiding-place.

Not only then are these beetles great purifiers and scavengers, but by burying dead bodies a little way beneath the soil, the bones in decaying manure the surface soil, and thus they are a help to agriculturalists.

How do these insects find out that there lies a mouse awaiting eating and burial? Is it done by sight, or is it done by smell, or by both combined, or is it done by some other sense of which at present we know nothing?

We do know that everything that lives on flesh has a powerful sense of smell.

Wasps.-Although these insects are fond of fruit they do a deal of good by destroying a number of injurious insects, and by purifying decaying and obnoxious matter.

The nests of some wasps are built in the hollows of trees, others hang freely down from the trees. When the nests hang down, their combs and cells are made of papery substance. 
This is made by the insect gnawing and crushing decaying wood, especially bark, with its jaws and mixing the crushed material with its saliva.

In this way a pulp is made

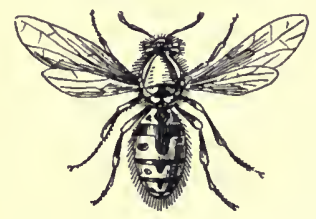

WASP. which is used in building the nest, and it dries into a kind of paper.

During the summer the larvae of the wasps are fed by the workers with freshly chewed insects, or with honey.

Wasps do not suck nectar from flowers as do bees, but steal it from certain bees, or else they form it in their stomach from sugary material drawn from sweet fruits.

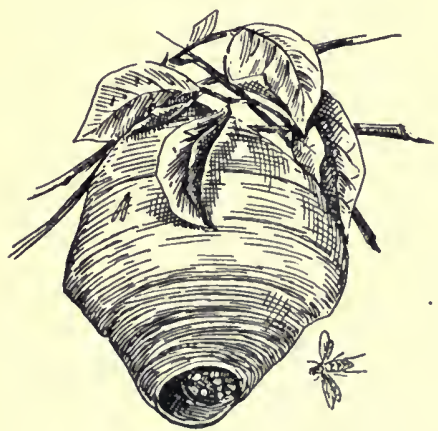

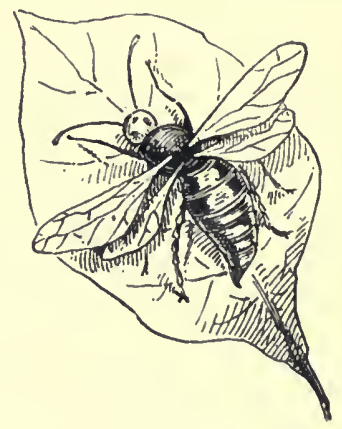

HORNET.

Wasps, as I dare say some of you know from experience, sting badly, but they do not sting unless attacked, or in defence of their nest.

If a wasp flies about you do not hit at it, 
because if you do, you frighten it or make it angry; in either case you stand a chance of being stung.

Dragon fly.-Don't kill a dragon fly. On warm days you will see these beautiful flies with their long bodies and gauze-like wings flashing like jewels in the sunlight.

They do not sting, are harmless, and do good by eating many injurious insects, especially some harmful butterflies and flies.

Their larvae live in the water and feed on the insects that they find there. They are said to devour fish spawn and therefore in this respect may be injurious.

The gold eye lace flies, aphis lions, the ant lion, and scorpion flies, all do good by killing aphis and many harmful and irritating flies.

You have read now of some of the useful insects; there are some others, but the ones you have read about are the best known.

\section{How Insects Increase and are Kept in Check.}

Under favourable conditions of climate, abundant food, and enemies not too numerous, an inseet will increase at an enormous rate.

A female of the eabbage-white butterfly lays about 200 eggs in heaps of 20 or 30, and she goes through this performance twice a year. Supposing half of these to survive and leave de- 
scendants, at the end of the year there would be in the world, with enormous appetites, feeding as hard as they can feed, 20,000 caterpillars as the descendants of one single butterfly.

In August, 1876, a swarm of the cabbage-white butterflies about a league broad, was seen flying over a part of Holland, and flying without cessation they took from twelve noon till seven in the evening to pass over.

This swarm had probably eaten all the food of their own district and had collected together in order to migrate to another district, where their own particular food was more plentiful.

The cabbage-white butterfly crawls forth from his pupa or resting-place in

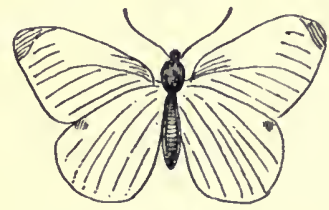

CABBAGK-WHFE (MALE). the spring, having passed the winter in the chrysalis condition, fixed to a tree trunk or wall. These chrysalises are exposed to extreme changes of weather, sun and frost, and this thins them out. Then the nuthatches, wrens, tits, and gold crests feed on them. Also ichneumon flies lay their eggs in them and so bring about their death.

It is reckoned that out of 100 chrysalises only about 10 survive these winter danger's.

In the spring some of the caterpillars that are hatched out of the 10 surviving pupae are 
HOW INSECT'S INCREASE AND KEPT IN CHECK. 245

destroyed by birds, caterpillars, flies and parasitic fungi.

Then the survivors of all this destruction may not be able to find sufficient food to satisfy their enormous appetites, and this again thins them down.

You therefore can readily understand why the cabbage-white must leave an enormous number of descendants, if it is not to be quite stamped out of existence.

You will find all through Nature that the greater the risks anything is exposed to the greater its power of reproduction.

It is the large area of cultivated crops that gives a ready and abundant supply of insect food.

Weeds don't grow together as erops do, therefore when the weeds or small masses of weeds are eaten, the caterpillar must die. Whereas when one portion of a crop is eaten, the caterpillar easily passes on to another portion of the crop.

The worst insects are those like the silverY-moth and cockehafer, which are all-round feeders, and will devour any crop or part of any crop that you place in the ground.

But there are others, and these perhaps the majority, that will only feed on a particular crop, or one closely related to it. 


\section{Rotation of Crops thins out Insects.}

So if after roots you grow a straw crop, the insects that the year before lived on the root crop will not find the food of the straw erop suitable for them, and they will therefore decrease considerably in numbers.

You will therefore understand how wise is the system of the rotation of crops, even as a protection against injurious insects.

It is found that the destruction amongst woods and forests from insects where rotation cannot be carried out is very considerably greater than amongst field crops, where a wise rotation is followed.

The attack of caterpillars and other insect pests on forests always lasts for many years.

In a forest, one generation of insects, having increased in numbers, leaves descendants who find all round them in abundance, just the very food that they require, and as a consequence these again increase in numbers till the whole forest swarms with them.

\section{One Insect Checks Another.}

Sometimes two different species of insect attack the same plant, often with very satisfactory results in getting rid of an insect plague.

In a certain district of Holland the oaks are 
largely cultivated for the sake of their bark. In the years 1875 to 1877 , the oak flea beetle increased in such numbers that they stripped every bud off the oak trees, so that no green leaf could be seen.

But in this same district the year 1878 was a cockchafer year, which occurs, as you have read, in certain districts every four or five years. When the oak buds were developing in April the cockchafer left the ground and attacked the buds and unfolding leaves. 'I'bese insects ate every single thing, buds, leaves, etc., leaving the trees bare. Then the flea beetle appeared on the oak branches, but the cockchafers had forestalled them, and eaten all the flea beetle's food, and so the flea beetle died of starvation. The cockchafer was the means of destroying the flea beetle, and thus brought the plague to an end.

Certain animals and birds are very useful to the farmer in eating the destructive insectsMoles, Shrews, Hedgehogs, Bats ; insect-eating birds, namely, Cuckoos, Swallows, Swifts, Goat Sucker, Tree Creeper, Nuthatch, Wren ; all sharpbeaked singing birds-Nightingale, Redstart, Robin; all Grasshopper-Warblers, Linnet, Wagtail, Peewit, Goldcrest, and all the Tits. The following are mostly beneficial : Hedgehog, Mole, Thrush, Starling, Chaffinch. 


\section{Prevention better than Cure.}

It is cheaper and better in the long run to take steps to prevent an illness attacking you-that is, to live a life that will enable you to resist an illness-than to go to a doctor for cure after you have taken the illness.

And so it is with the insect plague. Manage your land in such a manner that an insect plague becomes almost impossible. Keep the land, headland, and ditches, free of weeds. Follow a rotation of crops, so that the insects cannot obtain the same kind of food two years running.

Manure your land well, so that the crops grow quickly past their seed leaves, for it is these seed leaves that are such excellent food for insects, and if such leaves are eaten the plant has a poor future.

When you can, burn all your weeds and refuse, and don't throw them on the land or on to the dung heap.

Above all things, preserve your insect-eating birds, encourage them in every way you can. The insect-eating birds are probably the most valuable asset the agriculturalist possesses.

And to thin them down by killing them, or taking their nests, is an act of mad, ignorant folly.

GLASGOW: PRINTED AT THE UNIVERSITY PREAS BY ROBERT MACLEIOSE AND CO. 


\section{A COUNTRY READER I.}

\section{By H. B. M. BUCHANAN, B.A.}

\section{PRESS AND OTHER OPINIONS}

One of H.M. INSPECTORS of Schools writes :

"It is quite one of the best books of the kind, if not the best, I have encountered, and should be of the utnost value to the rising generation."

An OFFICIAL at the Educational Department writes:

"I think your book is quite admirable. It reads delightfully; there is more real 'science attitude of mind' in it, with all its simple language, than in any readers I have before seen, and the pictures are simply splendid. It is infinitely worth all the labour and thought that you have lavished on it, and I heartily congratulate you on getting it out."

A TOWN SCHO(LMASTER writes:

"I beg to congratulate you most heartily on your little book, A Country Reader. Although not a rural teacher, but the head master of a very large mixed school in a manufacturing district, the subject and matter appeal none the less both to myself and the children. What a delight it is to come across a reader with such a breadth of treatment-teaching the greatest of all lessons on every page, Observe, Observe, Observe. Wishing the book every success. (Signed) "W. M. WILSON, "Central Board School, Hebden Bridge."

Messrs. BENNION, HORN \& CO., Booksellers, of Market Drayton, write :

(Messrs. Bennion are Proprietors of several country papers with circulation in the Agricultural Districts, and their trade is almost exclusively with people connected more or less with the Land. Their opinion, therefore, as to the requirements of the Agricultural population, is of valıe.)

"I enclose a schoolmaster's letter re your book, whom I lent it to. I trust the sale will be as satisfactory as my opinion of the book-the most useful I have ever seen to place in the hands of country and town children."

A COUNTRY SCHOOLMASTER'S letter above referred to:

"Thanks for loan of book called A Country Reader. I have much enjoyed reading it. Please tell $\mathrm{Mr}$. Buchanan that 1 consider it an exceedingly useful publication for schools, for it ought to arouse the interest of the children, and cause them to take a more intelligent pleasure in their surroundings. I should be glad to know about its price to schools."

MR. W. GODWIN writes:

(Mr. Godwin judges live stock at many Agricultural Shows. His opinion therefore, from the tcchnical point of view, is of value.)

"Permit me to offer my congratulations upon your interesting little book, A Country Reader. Pardon me for saying, it is alnıst too practical for an estate landowner, and might well have been written by a farmer well acquainted with the live stock it delineates. It should greatly benefit the young of both sexes connected with country life." 
Mr. EDWARD CLODD writes:

(Mr. Clodd is the author of many useful and accurate popular scientific works ; his opinion therefore, fron the scientific view, is of value.)

"It seems to ine excellent for the purpose you keep in view; the stimulating of inquiry-while the practical suggestions which follow the exposition, if acted on, should make the poultry and egg trade wake up. The references to animal ancestry habits are apposite and interesting."

Mr. H. RIDER HAGGARD writes :

"Many thanks for your Country Reader. I think it an excellent little work, and likely to prove very useful."

DR. A. CONAN DOYLE writes:

"Very many thanks for the most interesting little book."

'THE SPEC'ATOR.- "It is a 'reading-book,' so that while our.country school boys and girls are learning to read aloud, they can also be learning the desirable information contained in it, and at the same time gain from the pictures-what children pick up more quickly in that way than in any other available indoors-what first-class animals, such as Lord Rothschild's dairy shorthorns, or the Duke of Wellington's cart teams, or a prize Aberdeen-Angus bull, or a good retriever or gamecock or Dorking hen, or South Down sheep, ought to look like. It is all quite short, and yet quite readable, and not at all like 'lessons,' while at the same tinie thoroughly up to date, and good enough for reference by the most practical person. The dairy chapters are excellent, with a photograph of a most pleasing dairy-maid in a nice clean tiled dairy."

METHODIST SUNDAY SCHOOL RECORD. - "We have great pleasure in introducing this book to the attention of our many country readers. The work is intended as a Reading Book for Schools, but no man, gentle or simple, living in the country can read it without profit. It is scholarly without a trace of pedantry. It contains an immense amount of information, not generally known, of the history of the horse, the ox, the pig, the sheep, the dog, poultry and bees, and of the farmer's friends and foes, birds and insects. The greatest value, however, lies in teaching the habit of observation, the cultivation of right feeling towards our domestic animals, and the inculcation of their proper treatment. We cannot conceive anything more likely to be useful to our country boys and girls than the study of this charming little work. We wish a copy were in every village library, and especially in our Sunday School Libraries."

GL $O B E$. - "We could wish that this admirable 'Reader' were adopted in the Board schools of our overcrowded cities and towns, where children, for all their unnatural surroundings, are kcenly interested in country life.

"Such a book in the hands of a wise and sympathetic schoolmaster would help to breed in the ininds of city children a desire for the farming life which might one day influence their choice of a career, tc the great advantage of the State. But its first use is to the village child, and its adoption in our country schools might almost be termed a national duty. As a rule the country child is quite ignorant of his surroundings, and certainly grows up in the very darkest jgnorance of modern scientific farming."

FIELD. - "The chapters deal, in a first division, with elementary facts, stated in a nanner to impel interest, respecting farm life in the countryhorses, cattle, pigs, sheep, dogs, poultry, and bees, and in Part 1I. with the life of our wild animals, birds, and insects. The illustrations are for the most part very good."

$N A T U R E$ - - "Common domestic and wild animals are described in this book in a simple and instructive style, capable of being understood by the elder children in village schools, and by adults who are only familiar with words of everyday life in the country. The book will impart to those who read it an intelligent knowledge of animal life in and around a $\operatorname{tarm}$. The illustrations, mostly reproduced from photographs, are very fine." 
$G U A R D I A N$. - "Deals with such subjects as the care of horses, cattle, pigs, sheep, poultry, and bees; and the little book contains the latest and most intelligent theories on these matters, together with much practical information. . . . Mr. Buchanan has studied his subject thoroughly and speaks with an authority which practical experience alone can give."

EDUCATIONAL NEWS.- "This Reader is given in two parts-Farm Life of the Country, and Wild Life of the Country. Part I. deals with the borse, cattle, pig, sheep, country dogs, poultry, and bees; whilst Part II. treats of animals, birds, and insects. One very useful feature of the book is the numerous practical hints it supplies to its readers. "The manual is intended for the elder children of village schools, and a more stimulating volume could not be placed in their hands. It is written with considerable literary ability, and altogether reflects great credit on its author. The work is copiously illustrated, and strongly bound."

IRISH TEACHER' JUURNAL. - "This admirable Reader is intended for the elder pupils who can read with ease and fluency. The author has endeavoured to use short words and simple sentences. He has produced a work at once interesting and scientific. His explanation of the squeals of the pig, the greedy habits of the dog, and the dainty mode of feeding of the cat, are not only interesting of themselves, but calculated to make pupils observe more closely familiar objects which would otherwise pass almost unnoticed. We are living at a time when some of our most thoughtful people are anxious to turn the drift of inigration from the town to country, and we know of nothing better calculated to attract people to the country than such readers as the one placed at the head of this notice. It is beautifully printed: the illustrations are numerous and excellent, and the general turnout is characterised by that excellence which distinguishes all the publications of the eminent house of Macmillan."

IRISH FARMING WORLD.—" The attractive little volume is just such a work as one would like to see in every village school throughout the country. Of course we have an 'Elementary Text Book for Use in Irish National Schools,' but we do not think that the ends of that work would at all be interfered with by the introduction of the Country Reader. On the contrary, we think that this work would induce pupils to take an additional interest iil the Text Book, for it literally breathes of the country and, on account of its general air of freshness and clearness, is certain to be highly appreciated by all who peruse its pages, for the sketches of country life which it contains afford really excellent reading."

COUNTY GENTLEMAN.-"Mr. H. B. M. Buchanan, Hales, nea! Market-Drayton, has just issued through Messrs. Macmillan $A$ Country Reader, for the use of children in village board schools, which is founded upon an excellent idea. Instead of the usual trite twaddle considered suitable for their never-likely-to-be-developed minds, be has chosen interesting aud instructive little articles of all sorts of country subjects with a view of stimulating the interest and observation of the children, and has found it work with good results in his own neighbourhood. Such an idea properly carried out throughout England might help to check the tide of rural exodus by inculcating into the modern rustic youth that love of the country so conspicuously absent."

AGRICULTURAL WORLD. - "This useful little book is not neant for very young children, but for the elder children of our village schools-children who are supposed to read with ease, and are expected to know the meaning of ordinary English words. It is simply and pleasantly written, and contains a variety of excellent illustrations."

TEACHERS'AID.- "We cannot speak too highly of this beautiful and instructive reader. The matter is excellent and the pictures are gems. We can imagine the boys and girls of country schools going into raptures of delight over it, and we should have no hesitation in substituting it for any other Reader which may be in use. Town and urban scholars will fiud much to interest them in its pages." 
SCHOOLMASTER. - "This is a new departure as School Readers, and will be welcomed by all those who desire to awaken in our children a love of country life. Living in the very heart of rural England, the author, himself a naturalist of ability, a keen observer, and an ardent lover of nature, reminds us that the chief object of his interesting book is to direct the observation of the children, and to excite an interest in and a fondness for the varied life that lies around them. The book is devoted entirely to animal life-Part I. dealing with the chief domestic animals of the farm, Part II. with the chief wild animals, birds, and insects. Though full of scientific knowledge, it is not in any degree a text book, but a pleasant and chatty 'Reader' that can hardly fail to arrest the interest of juvenile and adult. For instance, the chapter on 'The Horse,' which occupies the first thirty-six pages, treats of the history of that creature from the prehistoric days when he was the prey of the 'grim grey wolf,' to the most recent times when there has been evolved the "thoroughbred," the 'hunter,' and the 'dray horse.' Most of the other animals are treated on this plan, and their life history reads like a romance. The book is beautifully illustrated, well got up, and strongly bound."

PUPIL TEACHER. - "Within the past few months several Readers designed for use in village schools have appeared. 'These Agricultural, Farm, or Country Readers have been written to meet a new demand, that is, to supply interesting readable books in language suitable for the capacity of the average literary abilities of the village scholar, and having the aim of inculcating a love of the country. Of all such books we have seen, the one produced by $\mathrm{Mr}$. Buchanan is the most useful, being practical, well illustrated, simple, and enthusiastic. 'The book is not too exhaustive; to have been so would have defeated the object as a Reader, for such books conform to recognised ideas as to length and chapters; hence omission of subjects which some may feel ought to be included is unavoidable, but it would be difficult to improve on the selection given as well as the style in which the matter is set forth."

QUEENSLAND EDUCATIONAL JOURNAL.-"The occupations, animals, and plants, that form such an important portion of country life, are treated here in simple language, and very complete detail. An interesting feature of the work is the life history of some common destructive insects."

SOUTH AFRICAN EDUCATIONAL NEWS.-"A very adinirable Reader. . . 'Familiarity breeds contempt' is a proverb peculiarly true to country children. This book should do much to remove the reproach, as it is eminently calculated to carry out the writer's object, viz., to arouse the observation of the children, and so to excite an interest in the varied life and work that lies around them."

\section{BY THE SAME AUTHOR.}

COUNTRY READER II. Illustrated. Is. 6d.

Contents. - The Goat. The Ass. The Cat. Our Common Reptiles. Fish of our Ponds and Streams. Pastures. Good Grasses for Feeding. Useless Grasses for Feeding.

\section{COUNTRY READER III. [In preparation.}

Contents. - Simple Principles of Manures. Seed Bed. Straw Crops. Root Crops. Cottage Gardens. Pigs, Poultry, Ducks and Geese, Rabbits and Pigeons. Some Hints on the Management of a small Grass Holding. 

This book is DUE on the last date stamped below

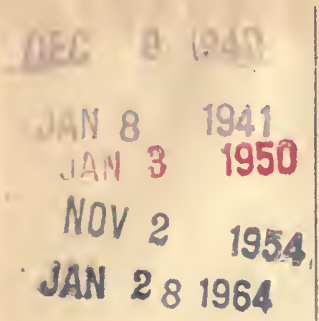

Form L-9-10m-5,'28 
n $\varepsilon L$

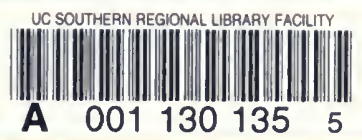

$$
\begin{gathered}
S \\
495 \\
1385 c
\end{gathered}
$$

USCOLL,

GFL.

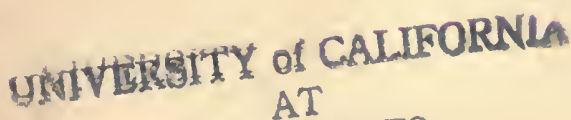

AT

LIS ANGELES

IIBRARY 
